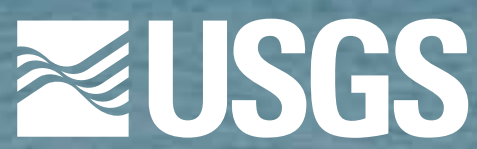

science for a changing world

Prepared in cooperation with the Federal Emergency Management Agency, the U.S. Army Corps of Engineers - Little Rock and Memphis Districts, and the Arkansas Natural Resources Commission

\title{
Analysis and Inundation Mapping of the April-May 2011 Flood at Selected Locations in Northern and Eastern Arkansas and Southern Missouri
}

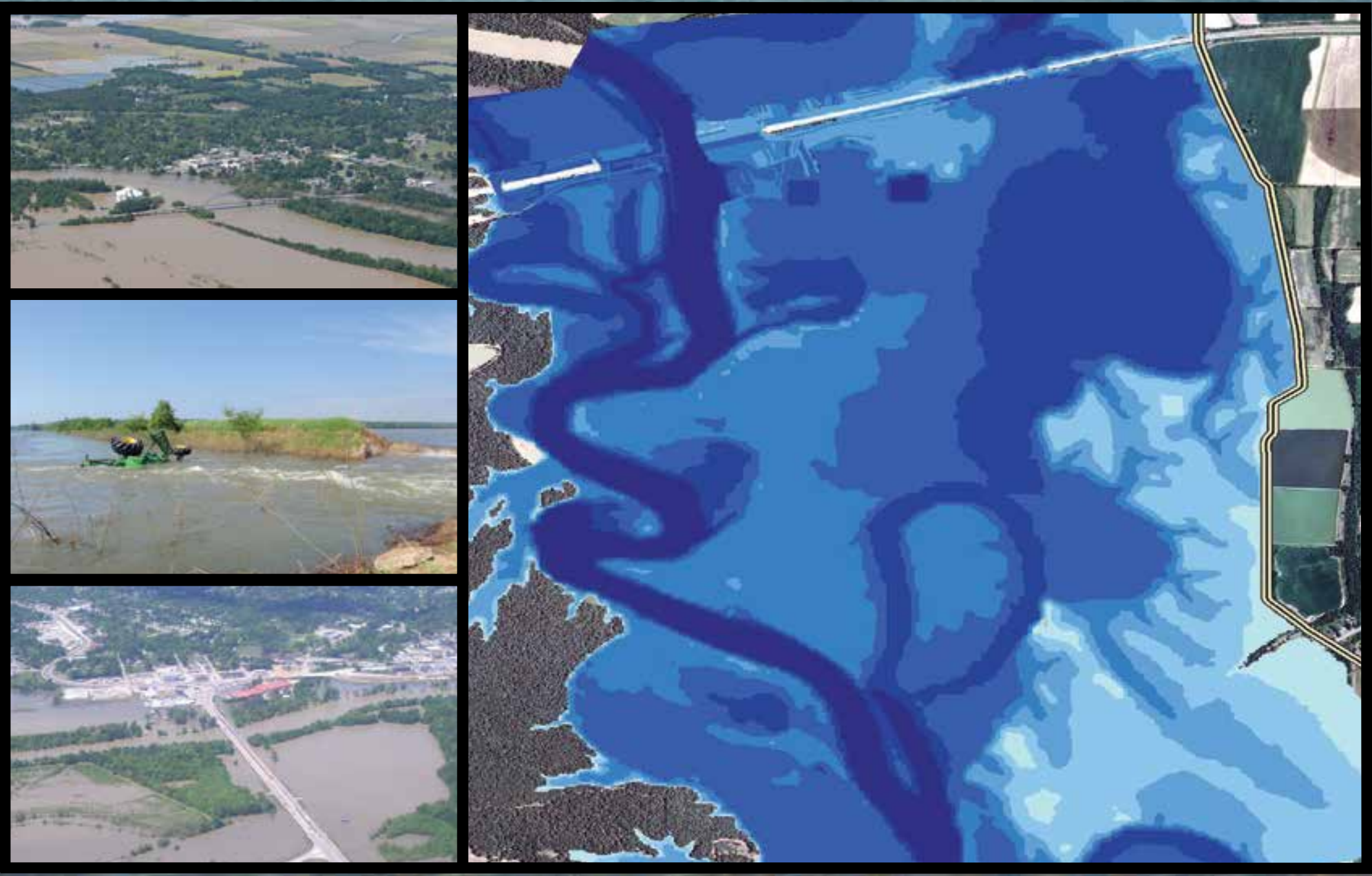

Scientific Investigations Report 2013-5148 


\section{Front cover:}

Top left, White River Bridge at Des Arc, Arkansas (photograph by Tabitha Clarke, National Weather Service).

Middle left, Black River flooding as a result of levee breach (photograph by Catherine Funkhouser, U.S. Army Corps of Engineers).

Bottom left, Black River at Pocahontas, Arkansas (photograph by Tabitha Clarke, National Weather Service).

Right, Part of inundation map showing flood-peak extent and water depth for the Interstate-40 crossing with the White River, Arkansas. The complete map can be found on figure 13 of the report.

Background, Swollen White River flood waters (photograph by Drew Westerman, U.S. Geological Survey). 


\section{Analysis and Inundation Mapping of the April-May 2011 Flood at Selected Locations in Northern and Eastern Arkansas and Southern Missouri}

By Drew A. Westerman, Katherine R. Merriman, Jeanne L. De Lanois, and Charles Berenbrock

Prepared in cooperation with the Federal Emergency Management Agency, the U.S. Army Corps of Engineers - Little Rock and Memphis Districts, and the Arkansas Natural Resources Commission

Scientific Investigations Report 2013-5148 


\section{U.S. Department of the Interior \\ SALLY JEWELL, Secretary}

\section{U.S. Geological Survey \\ Suzette M. Kimball, Acting Director}

\section{U.S. Geological Survey, Reston, Virginia: 2013}

For more information on the USGS — the Federal source for science about the Earth, its natural and living resources, natural hazards, and the environment, visit http://www.usgs.gov or call 1-888-ASK-USGS.

For an overview of USGS information products, including maps, imagery, and publications, visit http://www.usgs.gov/pubprod

To order this and other USGS information products, visit http://store.usgs.gov

Any use of trade, firm, or product names is for descriptive purposes only and does not imply endorsement by the U.S. Government.

Although this information product, for the most part, is in the public domain, it also may contain copyrighted materials as noted in the text. Permission to reproduce copyrighted items must be secured from the copyright owner.

Suggested citation:

Westerman, D.A., Merriman, K.R., De Lanois, J.L., and Berenbrock, Charles, 2013, Analysis and inundation mapping of the April-May 2011 flood at selected locations in northern and eastern Arkansas and southern Missouri: U.S. Geological Survey Scientific Investigations Report 2013-5148, 44 p., http://pubs.usgs.gov/sir/2013/5148/. 


\section{Acknowledgments}

The authors acknowledge the assistance of Tabitha Clarke of the National Weather Service, Little Rock, Arkansas, for providing precipitation data and flood photographs; Elmo Webb and Catherine Funkhouser of the U.S. Army Corps of Engineers-Little Rock District for assisting with high-water-mark collection and levee information; Ricky Hoover, Gene McAvoy, and Donald Davenport of U.S. Army Corps of Engineers-Memphis District for surveying high-water marks and providing general information about levees and the flood event. Thanks to the Arkansas State Highway and Transportation Department for providing bathymetry of the Arkansas River, survey data near the Interstate-40 crossing with the White River, and high-water marks of the flooding event. Special thanks to Elizabeth Murphy of U. S. Geological Survey-Illinois Water Science Center for technical support in the creation of the inundation maps. 



\section{Contents}

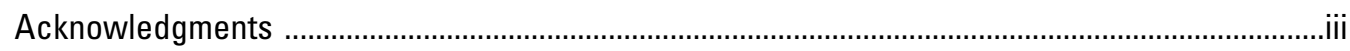

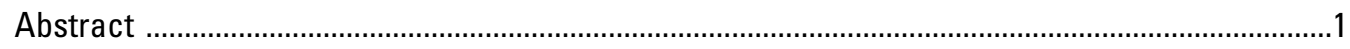

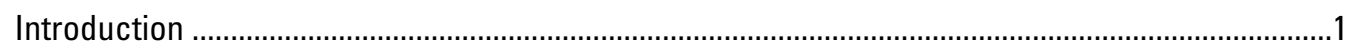

Purpose and Scope ..................................................................................................

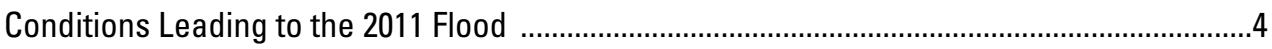

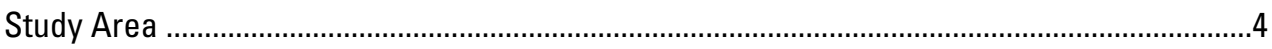

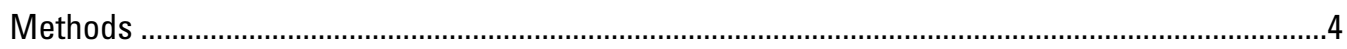

Computing the Magnitudes of Peak Streamflow …….............................................................

Estimating Annual Exceedance Probabilities of Peak Streamflows and Stages .....................6

Expected Moments Algorithm (EMA) Method .................................................................

Multiple Grubbs-Beck Test for Detecting Low Outliers ...................................................

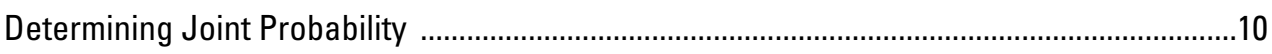

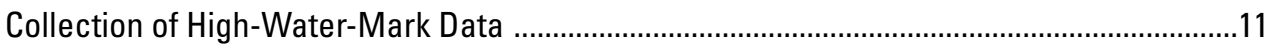

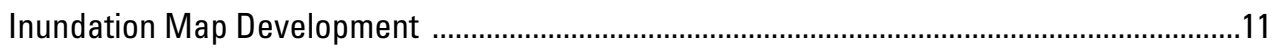

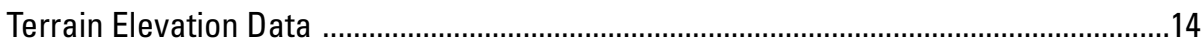

Uncertainty in Flood-Peak Inundation Maps ............................................................15

Disclaimer for Flood-Peak Inundation Maps ...........................................................16

Flood Analysis and Inundation Mapping for the Flood of April-May 2011 in Northern and Eastern Arkansas and Southern Missouri .......................................................................16

Magnitudes and Estimated Flood Frequencies of Peak Streamflows .....................................16

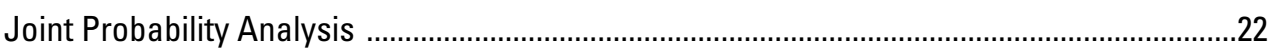

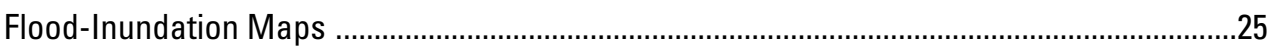

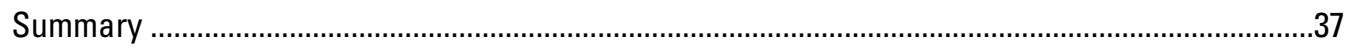

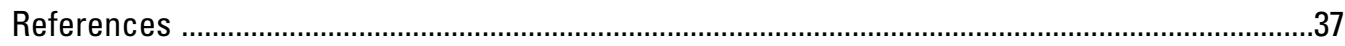

Appendix 1. High-water-mark identifiers, locations, elevations, and quality indicators for two stream reaches on the White River and two on the Black River; the vicinities of the communities of Holly Grove and Cotton Plant, Arkansas; a reach of the White River that includes the crossing of Interstate 40 north of De Valls Bluff, Ark.; and the Tailwaters of Beaver Dam near Eureka Springs, Ark., Table Rock Dam near Branson, Missouri, and Bull Shoals Dam near Flippin, Ark. 


\section{Figures}

1. Map showing Federal Emergency Management Agency Federal Disaster Declaration counties in Arkansas and streamgages in the study area

2. Maps showing NEXRAD data (WSR-88D) identifying the heavy precipitation across the state of Arkansas on (A) April 19-25, 2011, (B) April 26-28, 2011, and

(C) May 1-3, 2011, during the 2011 floods

3. Map showing study area showing location of streams, streamgages, and mapped inundated areas

4. Graph showing log-Pearson Type III flood-frequency curves for Mississippi River at Helena, Arkansas (07047970), streamgage using the expected moments algorithm (EMA) with and without the multiple Grubbs-Beck (MGB) test for censoring low outliers

5. Graph showing concurrent daily mean streamflow for the Mississippi River at Helena, Arkansas (07047970), and daily mean streamflow for the White River at Newport, Ark. (07074500)

6. Graph showing concurrent daily mean streamflow for the Mississippi River at Helena, Arkansas (07047970), and daily mean stage for the Cache River at Brasfield, Ark. (07077600)

7. Map showing flood-peak extent and water-depth inundation map for the White River from Batesville to Newport, Arkansas

8. Map showing flood-peak extent and water-depth inundation map for the White River from Newport to Des Arc, Arkansas

9. Map showing flood-peak extent and water-depth inundation map for the Black River from Corning to Pocahontas, Arkansas

10. Map showing flood-peak extent and water-depth inundation map for the Black River from Pocahontas to the confluence with the White River near Newport, Arkansas

11. Map showing flood-peak extent and water-depth inundation map for the town of Holly Grove, Arkansas, adjacent to a tributary of the White River, Maddox Bay (also known as Dial Creek)

12. Map showing flood-peak extent and water-depth inundation map for the town of Cotton Plant, Arkansas, adjacent to the Cache River

13. Map showing flood-peak extent and water-depth inundation map for the Interstate-40 crossing with the White River, Arkansas

14. Map showing flood-peak extent and water-depth inundation map for the White River at Beaver Dam Tailwater near Eureka Springs, Arkansas

15. Map showing flood-peak extent and water-depth inundation map for the White River at Table Rock Dam Tailwater near Branson, Missouri

16. Map showing flood-peak extent and water-depth inundation map for the White River at Bull Shoals Dam Tailwater near Flippin, Arkansas 


\section{Tables}

1. Total precipitation at selected National Weather Service precipitation stations, Arkansas, April and May 2011

2. Recurrence intervals with corresponding annual exceedance probabilities for floodfrequency estimates

3. Sources and resolution for the digital elevation models (DEMs) used for inundation mapping ....

4. Site information for U.S. Geological Survey streamgage stations within the study area

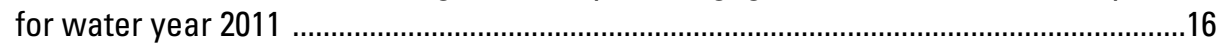

5. Flood-frequency analysis for selected streamgages ................................................18

6. Equation and flood thresholds for streamgages used for joint probability analysis ......23

7. Results of streamgage joint probabilities at selected streamgages paired with the Mississippi River at Helena, Arkansas, streamgage (07047970)

\section{Conversion Factors}

Inch/Pound to SI

\begin{tabular}{|c|c|c|}
\hline Multiply & By & To obtain \\
\hline \multicolumn{3}{|c|}{ Length } \\
\hline inch (in.) & 2.54 & centimeter $(\mathrm{cm})$ \\
\hline foot $(\mathrm{ft})$ & 0.3048 & meter $(\mathrm{m})$ \\
\hline mile (mi) & 1.609 & kilometer $(\mathrm{km})$ \\
\hline \multicolumn{3}{|c|}{ Area } \\
\hline square mile $\left(\mathrm{mi}^{2}\right)$ & 2.590 & square kilometer $\left(\mathrm{km}^{2}\right)$ \\
\hline \multicolumn{3}{|c|}{ Flow rate } \\
\hline cubic foot per second $\left(\mathrm{ft}^{3} / \mathrm{s}\right)$ & 0.02832 & cubic meter per second $\left(\mathrm{m}^{3} / \mathrm{s}\right)$ \\
\hline
\end{tabular}

Vertical coordinate information is referenced to the North American Vertical Datum of 1988 (NAVD 88).

Horizontal coordinate information is referenced to the North American Datum of 1983 (NAD 83).

Elevation, as used in this report, refers to distance above the vertical datum. 



\title{
Analysis and Inundation Mapping of the April-May 2011 Flood at Selected Locations in Northern and Eastern Arkansas and Southern Missouri
}

\author{
By Drew A. Westerman, Katherine R. Merriman, Jeanne L. De Lanois, and Charles Berenbrock
}

\section{Abstract}

Precipitation that fell from April 19 through May 3, 2011, resulted in widespread flooding across northern and eastern Arkansas and southern Missouri. The first storm produced a total of approximately 16 inches of precipitation over an 8-day period, and the following storms produced as much as 12 inches of precipitation over a 2-day period. Moderate to major flooding occurred quickly along many streams within Arkansas and Missouri (including the Black, Cache, Illinois, St. Francis, and White Rivers) at levels that had not been seen since the historic 1927 floods. The 2011 flood claimed an estimated 21 lives in Arkansas and Missouri, and damage caused by the flooding resulted in a Federal Disaster Declaration for 59 Arkansas counties that received Federal or State assistance. To further the goal of documenting and understanding floods, the U.S. Geological Survey, in cooperation with the Federal Emergency Management Agency, the U.S. Army Corps of Engineers-Little Rock and Memphis Districts, and Arkansas Natural Resources Commission, conducted a study to summarize meteorological and hydrological conditions before the flood; computed flood-peak magnitudes for 39 streamgages; estimated annual exceedance probabilities for 37 of those streamgages; determined the joint probabilities for 11 streamgages paired to the Mississippi River at Helena, Arkansas, which refers to the probability that locations on two paired streams simultaneously experience floods of a magnitude greater than or equal to a given annual exceedance probability; collected high-water marks; constructed flood-peak inundation maps showing maximum flood extent and water depths; and summarized flood damages and effects.

For the period of record used in this report, peak-ofrecord stage occurred at 24 of the 39 streamgages, and peakof-record streamflow occurred at 13 of the 30 streamgages where streamflow was determined. Annual exceedance probabilities were estimated to be less than 0.5 percent at three streamgages. The joint probability values for streamgages paired with the Mississippi River at Helena, Ark., streamgage indicate a low probability of concurrent flooding with the paired streamgages. The inundation maps show the flood-peak extent and water depth of flooding for two stream reaches on the White River and two on the Black River; the vicinities of the communities of Holly Grove and Cotton Plant, Ark.; a reach of the White River that includes the crossing of Interstate 40 north of De Valls Bluff, Ark.; and the Tailwaters of Beaver Dam near Eureka Springs, Ark., Table Rock Dam near Branson, Mo., and Bull Shoals Dam near Flippin, Ark. The data and inundation maps can be used for flood response, recovery, and planning efforts by Federal, State, and local agencies.

\section{Introduction}

Flood data are needed by Federal, State, and local agencies to make informed decisions related to flood hazard mitigation, planning, and response. For example, the Federal Emergency Management Agency (FEMA), the U.S. Army Corps of Engineers (USACE), and the Arkansas Natural Resources Commission (ANRC) need timely information on the magnitude and frequency of floods to help with flood response and to enhance emergency management, protect infrastructure, provide recovery guidance, and plan for future flood events.

Precipitation that fell from April 19 through May 3, 2011, resulted in widespread flooding across northern and eastern Arkansas and southern Missouri. High winds, tornadoes, and heavy rain began on April 19, 2011, followed by multiple severe storms that lasted for several days at a time. The first storm produced a total of approximately 16 inches (in.) of rain over an 8-day period, and the following storms produced as much as 12 in. of rain over a 2-day period (National Climatic Data Center, 2012a). Moderate to major flooding occurred along many streams within Arkansas and Missouri (including the Black, Cache, Illinois, St. Francis, and White Rivers) (fig. 1) at levels that had not been seen since the historic 1927 floods. As the flood moved down the Black River, levee breaches occurred that resulted in extensive flooding and damages to farmland, towns, and roadways (Catherine Funkhouser, U.S. Army Corps of Engineers-Little Rock, written commun., 2011; National Weather Service, 2012; Watkins, and others, 2011). The multiple lakes along the White River used to help manage and reduce floods were 


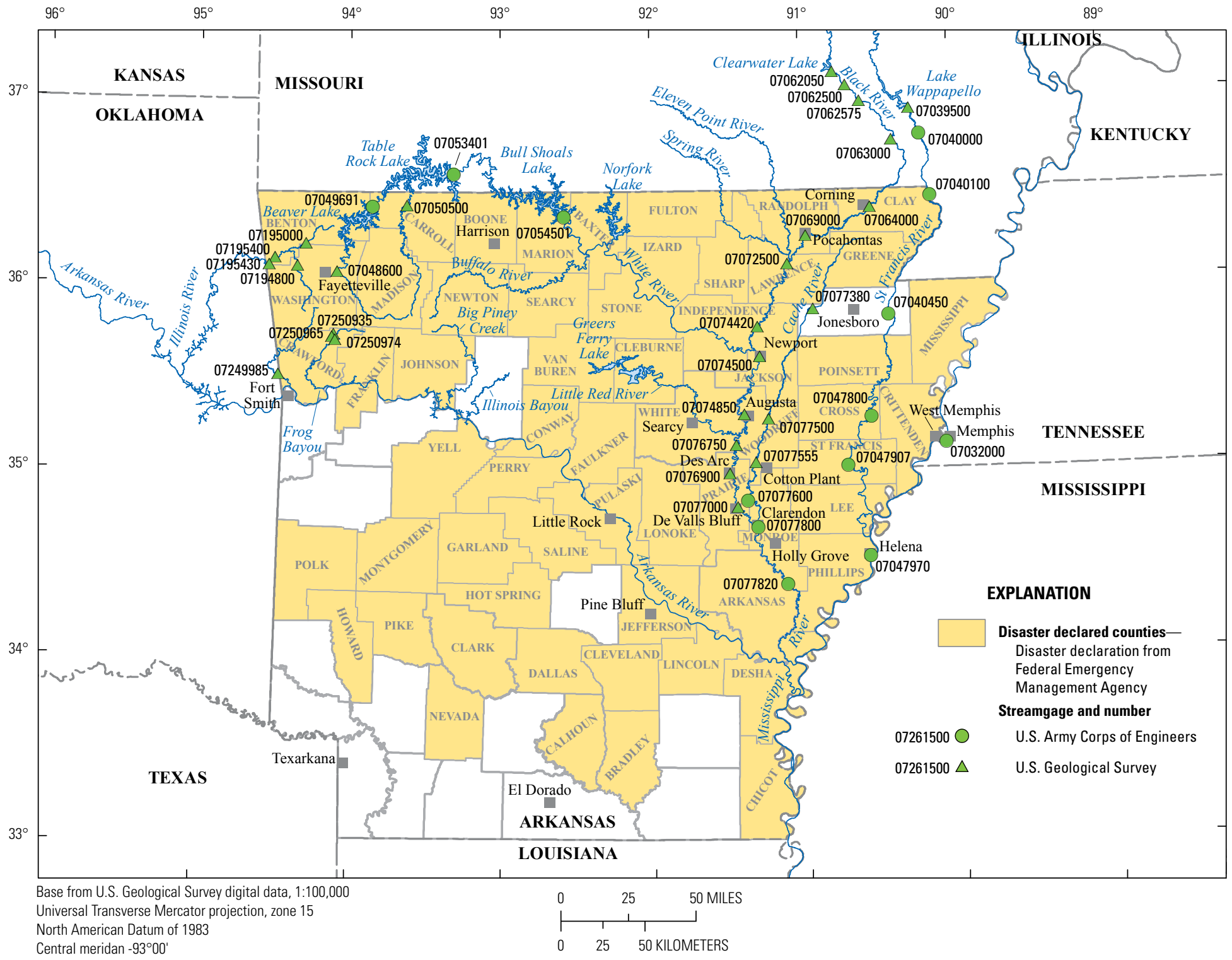

Figure 1. Federal Emergency Management Agency Federal Disaster Declaration counties in Arkansas and streamgages in the study area. 
quickly filled to capacity and record pool elevations were reached. The White River was slow to recede because it flows into the Mississippi River, which was already flooded from the intense precipitation and snowmelt that occurred further upstream (U.S Geological Survey, 2012a). The Mississippi River at Memphis, Tennessee, peaked at a stage (water level) of 48.03 feet (ft) on May 10, 2011, less than a foot lower than the record height set by the floods of 1937 (U.S Geological Survey, 2012a). The Mississippi River flowed upstream along the White and Arkansas Rivers causing backwater. The backwater effects, in addition to multiple levee breaches, altered the stage-streamflow relations; therefore, peak streamflow was not determined at several streamgages.

Travel was substantially disrupted by the flooding. A total of 82 sections of highways, including Interstate 40 and Highway 67/167, was closed (Arkansas State Highway and Transportation Department, 2011). On May 4, the White River was high enough to close the westbound lanes of Interstate 40 in eastern Prairie County, Ark. (mile marker 202). The eastbound lanes were closed by the evening of May 5 and remained closed for several days. This stretch of Interstate 40 generally handles approximately 30,000 vehicles a day, and traffic was substantially disrupted (Arkansas State Highway and Transportation Department, 2011). Traffic was diverted onto surrounding highways to avoid the flooded sections of highway. The detours involved 50 to 100 miles (mi) and several hours of extra driving. U.S. Highway 67/167 was closed in northern Pulaski County, Ark., through May 3 and early May 4. The White River flooded U.S. Highway 70 at De Valls Bluff (Prairie County, Ark.), and also flooded Highway 36 at Georgetown (White County, Ark.). The closing of Highway 36 left Georgetown isolated. The U.S. Department of Transportation provided Arkansas \$9.1 million to help reimburse the State for repairing or replacing highways, bridges, and other roadway structures resulting from the April through May floods (Federal Highway Administration, 2012).

Overflowing tributaries endangered lives and damaged property. The levee breaches on the Black River near Pocahontas, Ark., resulted in evacuation of prisoners from the Randolph County jail on April 28. On the morning of May 2, emergency management officials advised people to evacuate along the White River at Des Arc and Biscoe (both in Prairie County, Ark.). More evacuations took place in Jacksonport (Jackson County, Ark.) by evening. Also on May 5, evacuations were ordered at Gregory, McClelland, and Cotton Plant (all in Woodruff County, Ark.) because of overtopping of the levee along the White River and a swollen Cache River. The flooding of Arkansas crops and farmland cost an estimated 2,150 full- and part-time jobs and a \$335-million net loss in farm income (Watkins and others, 2011). In the end, the April-May 2011 flood claimed an estimated 21 lives in Arkansas and Missouri (National Weather Service, 2011).

The resulting devastation led Arkansas Governor Beebe to declare a State of Emergency for the flooded areas on April 25, 2011 (Federal Emergency Management Agency, 2011; fig. 1). On May 2, 2011, President Obama declared that a major disaster existed in the State of Arkansas (the Federal
Disaster Declaration can be found online at: http://www.fema. gov/disaster/1975). The Declaration made the Individual Assistance Program available to the affected individuals and households in Benton, Clay, Faulkner, Garland, Lincoln, Pulaski, Randolph, and Saline Counties. The Declaration also made the Public Assistance Program available to the State, eligible local governments, and certain private nonprofit organizations on a cost-sharing basis for emergency protective measures, limited to direct Federal assistance for work in Benton, Clay, Faulkner, Garland, Lincoln, Pulaski, Randolph, and Saline Counties. Finally, this Declaration made the Hazard Mitigation Grant Program assistance requested by the Governor available for hazard mitigation measures statewide. In all, 59 Arkansas counties received some form of Federal or State assistance (Federal Emergency Management Agency, 2011; fig. 1).

Flooding is the leading cause of natural-disaster losses (U.S. Geological Survey, 2006) and preventing the devastating effects associated with flooding is a major challenge. Properly documenting and understanding major floods is a vital service the U.S. Geological Survey (USGS) has provided throughout its history (for example, Murphy, 1904; Follansbee and Jones 1922; Grover, 1938; Wells, 1955; McCain and others, 1979; Parrett and others, 1993; Holmes and others, 2010; Holmes and Wagner, 2010). The USGS performs flood-frequency analysis on a series of annual-peak streamflow values measured at streamgages over a period of time. As more data become available, the ability to define the resulting flood magnitudes and corresponding frequencies typically improves. Therefore, it is beneficial to assess flood frequencies after each major flood event. To further the goal of documenting and understanding floods, the USGS, in cooperation with FEMA Region VI, the USACE-Little Rock (USACE-LR) and Memphis Districts (USACE-MEM), and ANRC, collected extensive flood information during and after the flood to appropriately document and analyze the flooding event.

\section{Purpose and Scope}

The purpose of this report is to provide meteorological and hydrological information pertaining to the April-May 2011 flood that occurred in northern and eastern Arkansas and southern Missouri. The report summarizes meteorological and hydrological conditions before the flood. The report presents flood analyses for streamgages in northern and eastern Arkansas and southern Missouri that include computed flood-peak magnitudes for 39 streamgages (26 USGS, 10 USACE-MEM, and 3 USACE-LR operated streamgages); joint and annual exceedance probabilities for 11 and 37 of the streamgages, respectively, paired to the Mississippi River at Helena, Ark. (07047970). Data on high-water marks (HWMs) and flood-peak inundation maps showing maximum floodpeak extent and water depths are presented and described for selected communities, the Tailwaters of three lakes, and for selected reaches of the White, Black, and Cache Rivers within northern and eastern Arkansas and southern Missouri. Information on flood damages and effects are summarized 
on the basis of information gathered for this report, including information obtained from FEMA, USACE, National Weather Service (NWS), and State and local agencies. The flood analyses and inundation maps provide flood documentation for FEMA's short- and mid-term use in recovery and hazard mitigation planning. Flood reports, such as this report, provide flood case histories, which can be used to educate the public and facilitate decisions by policy makers to better mitigate flood disasters.

\section{Conditions Leading to the 2011 Flood}

Widespread flooding occurred across the Lower Mississippi Valley because of a combination of late spring runoff from record snowmelt in the Upper Mississippi River Valley and the coincident heavy precipitation in late April and early May (National Weather Service, 2012).Three major storm events (April 19-25, 2011, April 26-28, 2011, and May 1-May 3, 2011) contributed to the overall flood event with similar stream basins in Arkansas and southern Missouri receiving up to 15 in. of precipitation from each storm as shown by the Next Generation Radar (NEXRAD) collected data from the National Climatic Data Center (2012a; fig. 2). Total precipitation amounts for April measured at NWS precipitation stations (National Climatic Data Center, 2012b; table 1) were above normal precipitation amounts for the month. Precipitation totals ranged from 2.72 in. at Jonesboro, Ark., to 15.28 in. at Fayetteville, Ark. (National Climatic Data Center, 2012b; table 1). A cold front from the Great Plains pushed into Arkansas during the evening of April 30, 2011, and stalled, acting as a focused source for heavy precipitation. The heaviest precipitation was in the central part of the State of Arkansas, and it lasted for several hours. Satellite data showed storms were "back building" across central Arkansas beginning the evening of April 30, 2011. "Back building" means that while the first wave of storms moved to the east, new storms would develop on the storm's upwind side (generally on the western side); therefore, similar areas would repeatedly receive new precipitation amounts for several hours. The major part of heavy precipitation fell across the central third of Arkansas at approximately 1:00 a.m. central daylight time (CDT) on May 1, 2011, and lasted for several hours. By the evening, 2 to 4 in. of precipitation had occurred, and flash flooding began in some areas. Total precipitation amounts for May from precipitation stations (National Climatic Data Center, 2012b; table 1) were above normal. Precipitation totals ranged from 2.64 in. at El Dorado, Ark., to 11.91 in. at Fort Smith, Ark. After the storms, 20 in. (700-1,000 percent above normal) precipitation amounts were recorded in some tributary basins within a 2-week period (National Weather Service, 2012).

\section{Study Area}

This study focuses on major flooding that occurred primarily within three major stream basins - the White River Basin, the St. Francis River Basin, and the Arkansas River
Basin in northern and eastern Arkansas and southern Missouri. In addition, two streamgages on the Mississippi River were part of the study because of the importance of upstream and near record measurements during the flood analyses. The White River originates in northwestern Arkansas, crosses into Missouri, and flows back into Arkansas where it eventually joins with the Mississippi River; the river encompasses a drainage area of approximately 27,800 square miles $\left(\mathrm{mi}^{2}\right)$ (Sullavan, 1974). Major tributaries to the White River include the Black and Cache Rivers with drainage areas of approximately $8,500 \mathrm{mi}^{2}$ and 2,000 $\mathrm{mi}^{2}$, respectively (Sullavan, 1974). The St. Francis River, which drains approximately $8,400 \mathrm{mi}^{2}$, originates in southeastern Missouri and flows into the Mississippi River (Christensen and others, 1967). The Arkansas River drains approximately 170,000 $\mathrm{mi}^{2}$, but only tributaries in northern Arkansas were part of the study. The major tributary to the Arkansas River within the study area includes the Illinois River with a drainage area of approximately 1,600 $\mathrm{mi}^{2}$ (Galloway, 2008). Hydraulic structures regulating streamflow within the study area were included in the flood analyses and inundation mapping (fig. 3).

\section{Methods}

The methods used to compute flood magnitudes, to do frequency analyses of peak streamflows and stage, and to collect HWM data are described in this section of the report. Methods used to create flood extent and water-depth inundation maps also are described.

\section{Computing the Magnitudes of Peak Streamflow}

Peak streamflow or peak stage, or both, was determined for the April-May 2011 flood for 39 USGS and USACE streamgages in Arkansas and Missouri (fig. 1). USGS stage and streamflow data were collected using methods described by Rantz and others (1982). Streamflow was computed by a stage-streamflow rating curve (hereafter referred to as a rating curve) unique to each streamgage. Rating curves are developed by relating paired measurements of stage and streamflow over a wide range of streamflows. These paired measurements most commonly come from direct measurements of stage (observed/recorded) and streamflow at the streamgage (Rantz and others, 1982); if direct measurement is not possible, indirect hydraulic methods are used (Benson and Dalrymple, 1967). The rating curve can be extrapolated slightly beyond the highest measurement of stage/streamflow, depending upon available information controlling the hydraulic conditions (Kennedy, 1984). In the current study, flood-peak stages were obtained from stage sensor readings recorded by electronic data recorders or from surveyed HWMs. Direct or indirect streamflow measurements served as flood-event data points for rating-curve verification and extension. 

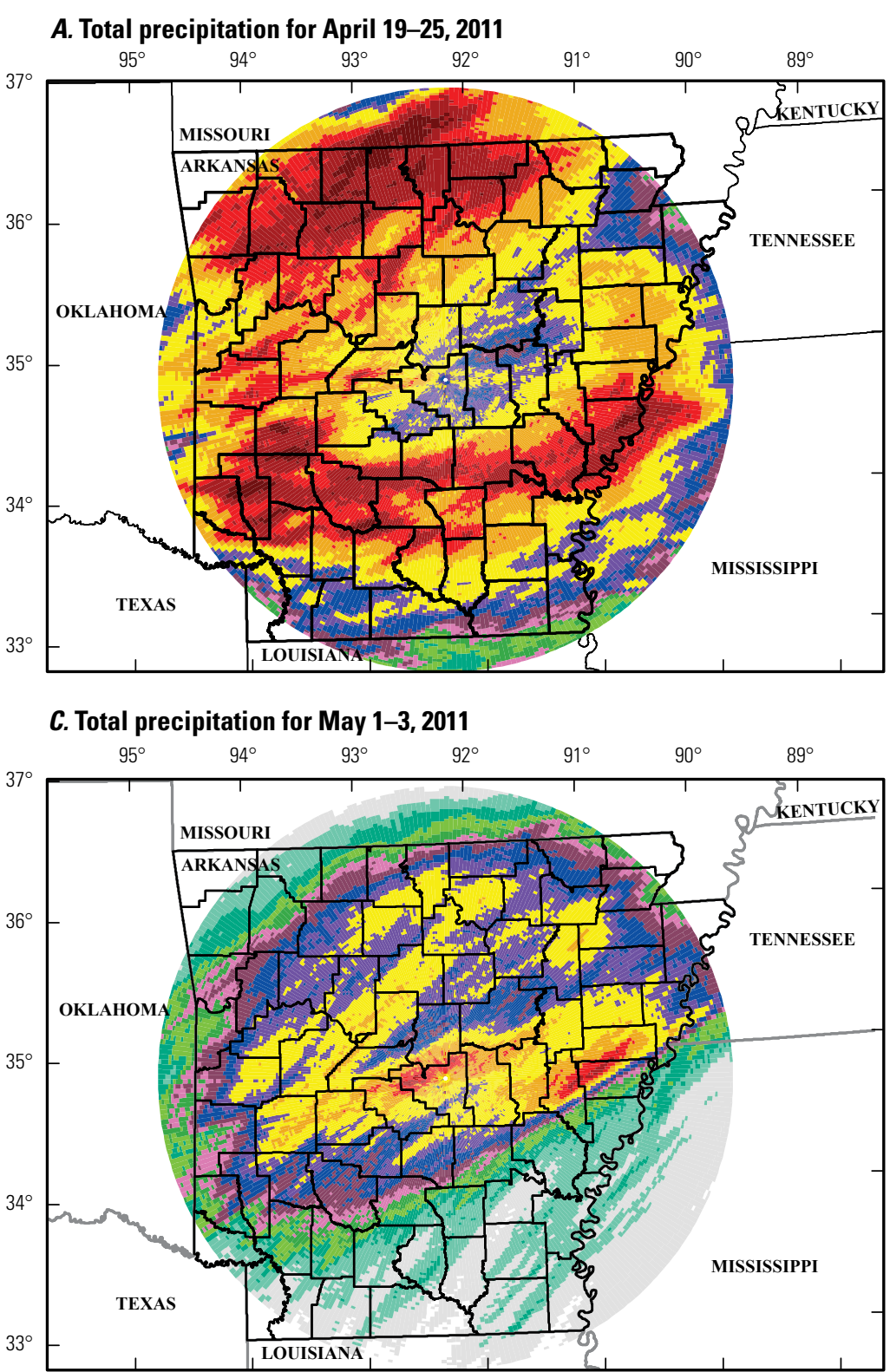

Base from U.S. Geological Survey digital data, 1:100,000

Albers Equal-Area Conic projection

North American Datum of 1983

Central meridan $-96^{\circ} 00^{\prime}$

\section{B. Total precipitation for April 26-28, 2011}

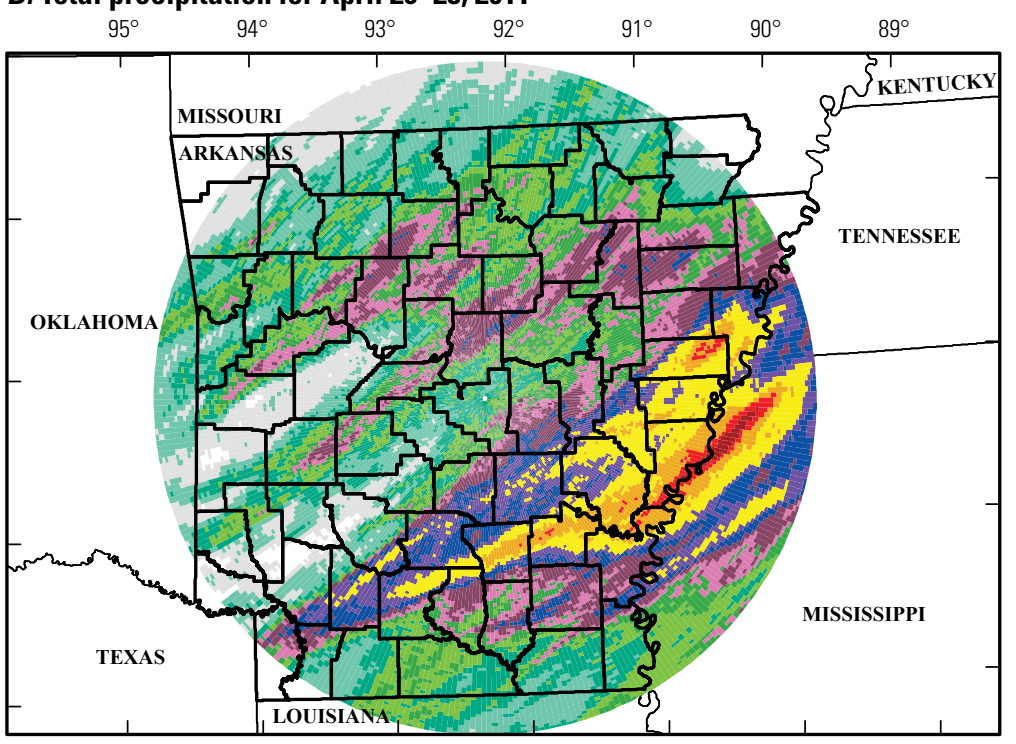

Precipitation data from Little Rock KLZK Radar National Climatic Data Center

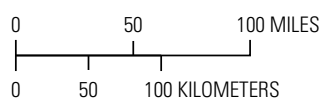

EXPLANATION

Total precipitation, in inches

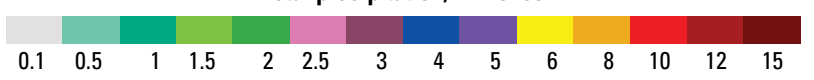

Figure 2. NEXRAD data (WSR-88D) identifying the heavy precipitation across the state of Arkansas on (A) April 19-25, 2011, (B) April 26-28, 2011, and (C) May 1-3, 2011, during the 2011 floods (National Climatic Data Center, 2012a). 
Table 1. Total precipitation at selected National Weather Service precipitation stations, Arkansas, April and May 2011 (National Climatic Data Center, 2012b).

\begin{tabular}{|c|c|c|c|c|c|c|c|c|}
\hline $\begin{array}{l}\text { National Weather Service } \\
\text { station name and identifier }\end{array}$ & $\begin{array}{c}\text { April } \\
2011 \\
\text { total } \\
\text { precipi- } \\
\text { tation } \\
\text { (inches) }\end{array}$ & $\begin{array}{c}\text { April } \\
\text { normal } \\
\text { precipi- } \\
\text { tation } \\
\text { from } 1981 \\
\text { to } 2010 \\
\text { (inches) }\end{array}$ & $\begin{array}{c}\text { Departure } \\
\text { from normal } \\
\text { precipitation } \\
\text { (April 2011 } \\
\text { total } \\
\text { precipitation } \\
\text { minus April } \\
\text { normal } \\
\text { precipitation) } \\
\text { (inches) }\end{array}$ & $\begin{array}{c}\text { Percent of } \\
\text { normal } \\
\text { precipitation } \\
\text { for April } 2011 \\
\text { (April } \\
2011 \text { total } \\
\text { precipitation } \\
\text { divided by } \\
\text { April normal } \\
\text { precipi- } \\
\text { tation) }\end{array}$ & $\begin{array}{c}\text { May } \\
2011 \\
\text { total } \\
\text { precipi- } \\
\text { tation } \\
\text { (inches) }\end{array}$ & $\begin{array}{c}\text { May } \\
\text { normal } \\
\text { precipi- } \\
\text { tation } \\
\text { from } \\
1981 \\
\text { to } 2010 \\
\text { (inches) }\end{array}$ & $\begin{array}{c}\text { Departure } \\
\text { from normal } \\
\text { precipitation } \\
\text { (May 2011 } \\
\text { total precipi- } \\
\text { tation } \\
\text { minus May } \\
\text { normal } \\
\text { precipita- } \\
\text { tion) } \\
\text { (inches) }\end{array}$ & $\begin{array}{c}\text { Percent of } \\
\text { normal } \\
\text { precipitation } \\
\text { for May } 2011 \\
\text { (May } 2011 \\
\text { total pre- } \\
\text { cipitation } \\
\text { divided by } \\
\text { May normal } \\
\text { precipi- } \\
\text { tation) }\end{array}$ \\
\hline Fayetteville, Ark., USW00093993 & 15.28 & 4.57 & 10.71 & 334 & 11.50 & 6.04 & 5.46 & 190 \\
\hline Harrison Ark., USW00013971 & 14.73 & 4.32 & 10.41 & 341 & 9.52 & 4.69 & 4.83 & 203 \\
\hline Jonesboro, Ark., USW00003953 & 2.72 & 5.02 & -2.30 & 54 & 9.71 & 4.61 & 5.10 & 211 \\
\hline Fort Smith, Ark., USW00013964 & 9.54 & 4.30 & 5.24 & 222 & 11.91 & 5.47 & 6.44 & 218 \\
\hline Little Rock, Ark., USW00013963 & 7.23 & 5.14 & 2.09 & 141 & 11.08 & 4.87 & 6.21 & 228 \\
\hline West Memphis, Ark., USW00053959 & 2.85 & 5.38 & -2.53 & 53 & 10.66 & 5.24 & 5.42 & 203 \\
\hline Texarkana, Ark., USW00013977 & 5.94 & 3.94 & 2.00 & 151 & 5.62 & 5.09 & 0.53 & 110 \\
\hline El Dorado, Ark., USW00093992 & 8.29 & 4.09 & 4.20 & 203 & 2.64 & 5.05 & -2.41 & 52 \\
\hline Pine Bluff, Ark., USC00035754 & 14.21 & 4.87 & 9.34 & 292 & 4.12 & 4.84 & -0.72 & 85 \\
\hline
\end{tabular}

\section{Estimating Annual Exceedance Probabilities of Peak Streamflows and Stages}

Annual peak streamflows at a streamgage are used to estimate flood magnitudes corresponding to selected annual exceedance probabilities. The terminology associated with flood-frequency estimates is shifting away from "recurrence intervals" to "annual exceedance probabilities" (AEPs). The use of AEP flood is now encouraged because it better conveys the probability of a flood of a given magnitude being equaled or exceeded in any given year (Holmes and Dinicola, 2010). For example, a 1-percent AEP flood (formerly known as the "100 year flood") corresponds to the streamflow magnitude that has a probability of 0.01 ( 1 percent) of being equaled or exceeded in any given year. The AEP is computed as the reciprocal of the recurrence interval "T," in years, multiplied by 100 (for example, $1 / 100 \times 100=1$ percent). The relation between $\mathrm{T}$-year recurrence intervals and the corresponding AEPs is shown in table 2.

AEPs at streamgages are computed by fitting a statistical distribution to the series of annual peak streamflows. The statistical distribution commonly used in the United States is the log-Pearson Type III distribution (Linsley and others, 1975; hereafter referred to as the LP3 distribution). Guidelines and computational methods for using the LP3 distribution are described in Bulletin 17B of the Hydrology Subcommittee of the Interagency Advisory Committee on Water Data (1982). The general procedures used for fitting the LP3 distribution in this study are described in the following sections of this report.

Annual peak stages also were used in the frequency analysis when annual peak streamflows were not available. Thus, frequency analyses for 13 streamgages were conducted using the annual peak stage. At 10 streamgages, the instantaneous peak stages were not available. Instead, the annual peak data were based on a daily maximum of hourly readings or the maximum of a single reading per day. This substitution seems reasonable because floods on these streams rise and fall slowly and the daily hourly stage or daily stage reading typically is nearly equal to the instantaneous peak stage. The flood-stage analysis was completed using a period of record that included historical streamflows that are representative of current hydraulic conditions. For example, the period of record used for a streamgage influenced by an impoundment began after the completion date. Flood-frequency estimates were not computed for streamgages with less than 10 years of annual peak data, the Interagency Advisory Committee on Water Data (1982) recommended minimum record length for floodfrequency analysis.

Flood-frequency estimates for the streamgages were computed by fitting the LP3 distribution to the logarithms (base 10) of the annual peak data (Interagency Advisory Committee on Water Data, 1982). Fitting the distribution requires calculating the mean, standard deviation, and skew coefficient of the logarithms of the annual peak record, which 


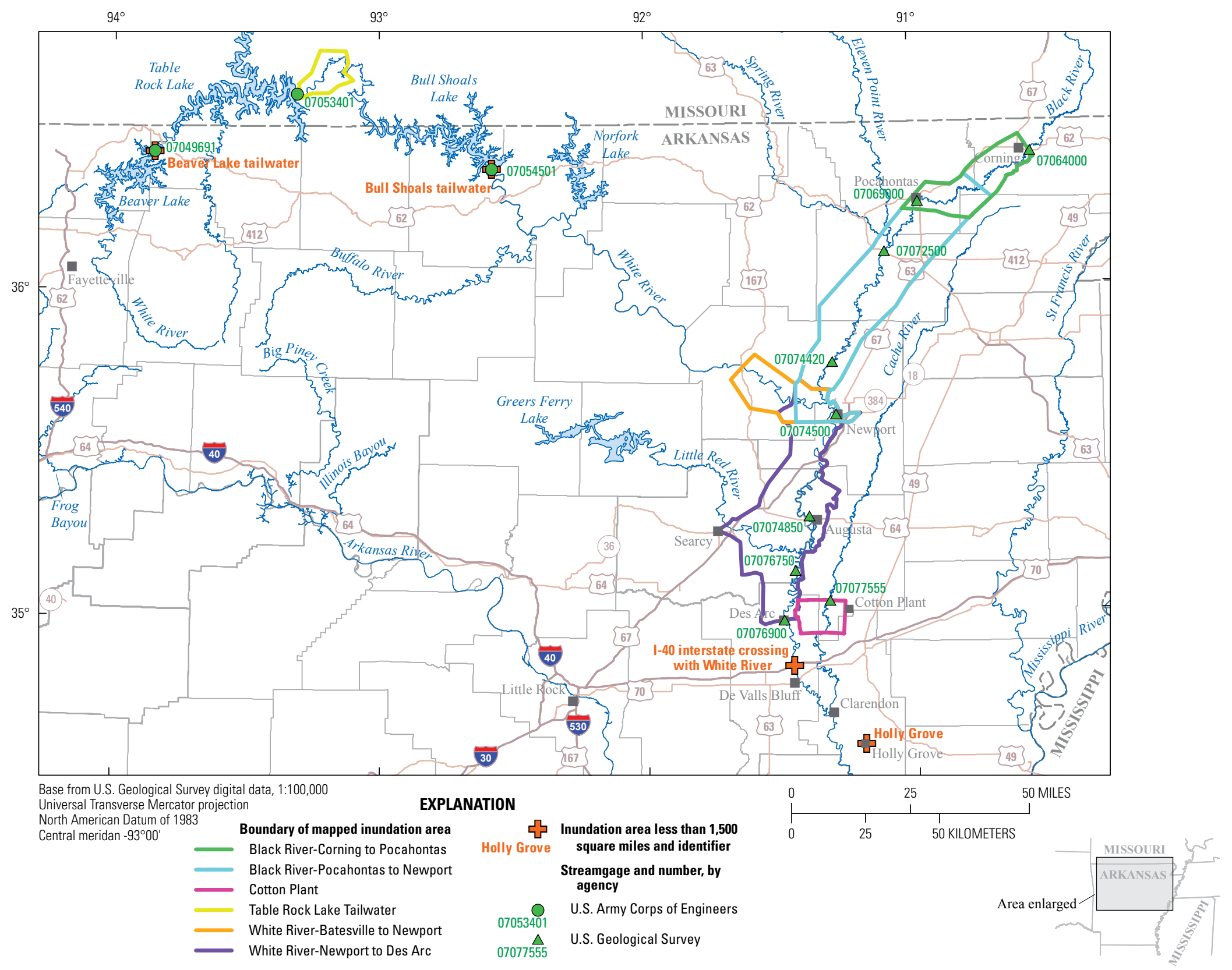

Figure 3. Study area showing location of streams, streamgages, and mapped inundated areas. 
Table 2. Recurrence intervals with corresponding annual exceedance probabilities for flood-frequency estimates.

\begin{tabular}{cc}
\hline $\begin{array}{c}\text { Recurrence interval } \\
\text { (years) }\end{array}$ & $\begin{array}{c}\text { Annual exceedance } \\
\text { probability } \\
\text { (percent) }\end{array}$ \\
\hline 2 & 50 \\
5 & 20 \\
10 & 10 \\
25 & 4 \\
50 & 2 \\
100 & 1 \\
200 & 0.5 \\
500 & 0.2 \\
\hline
\end{tabular}

describes the midpoint, slope, and curvature of the frequency curve. Estimates of the AEP flood are computed by inserting the three statistics of the distribution into the equation:

$$
\log Y_{P}=\bar{X}+K_{P} S
$$

where

$$
\begin{array}{cc}
Y_{p} \quad \begin{array}{c}
\text { is the P-percent annual exceedance probability } \\
\text { flood peak, peak streamflows in cubic feet } \\
\text { per second, and stage, in feet; }
\end{array} \\
\bar{X} \quad \begin{array}{c}
\text { is the mean of the logarithms of the annual } \\
\text { peak streamflow or peak stages; }
\end{array} \\
K_{p} \quad \begin{array}{l}
\text { is a frequency factor based on the skew } \\
\text { coefficient and exceedance probability, } \mathrm{P} ;
\end{array} \\
\begin{array}{c}
\text { and } \\
\text { is the standard deviation of the logarithms } \\
\text { of the annual peak streamflows or peak } \\
\text { stages. }
\end{array}
\end{array}
$$

The mean, standard deviation, and skew coefficient can be estimated from the available sample flood data (annual peak streamflows or stages), but a skew coefficient calculated from the small samples tends to be an unreliable estimator of the population skew coefficient. Accordingly, the guidelines in Bulletin 17B (Interagency Advisory Committee on Water Data, 1982) recommend that skew coefficients calculated from at-site sample peak streamflows (station skew) need to be weighted with the regional skew determined from an analysis of selected long-term streamgages in the study region. The value of the skew coefficient used in equation 1 is the weighted skew that is based on station skew and regional skew. However, at regulated sites or at sites where flood stage was used in the frequency analysis, the at-site ("station") skew was used instead of a weighted skew in equation 1 . The regional skew for peak streamflows at streamgages in this study was determined from the regional skew map of Bulletin 17B (Interagency Advisory Committee on Water Data, 1982).

A series of annual peaks (streamflow or stage) at a streamgage may include outliers that are substantially lower or higher than the majority of peaks in the record. The flood-peak data also may include information about the peak streamflow or stage that occurred outside the period when peak data were systematically observed or recorded. These peak data collected outside the period of systematic record are referred to as historical peak data and frequently are known to have been the largest during an extended period of time longer than the systematic record. Bulletin 17B (Interagency Advisory Committee on Water Data, 1982) provides guidelines for detecting outliers and provides computational methods for appropriate corrections to the data distribution to account for the outliers and historical peak information. Although these adjustments generally improve flood-frequency estimates, the expected moments algorithm (EMA) incorporates censored data (high and low outliers) and historical data more effectively (Cohn and others, 1997; Griffis and others, 2004) than the methods outlined in Bulletin 17B (Interagency Advisory Committee on Water Data, 1982).

\section{Expected Moments Algorithm (EMA) Method}

The EMA method was used for all sites in this study to determine LP3 at-site frequency estimates. For sites having systematic annual peak data for complete periods, no low outliers, and no historical data, the LP3 values from the EMA method are identical to those from the conventional methodof-moments procedure described in Bulletin 17B (Interagency Advisory Committee on Water Data, 1982). This is because EMA uses the method of moments and is compatible with all of the features of the current Bulletin 17B guidelines (Interagency Advisory Committee on Water Data, 1982). EMA can handle three types of at-site flood information: systematic record, information about the magnitude of historical floods, and information about the historical period when no large floods occurred. An iterative procedure is used to compute the method-of-moment estimates. Initially, these estimates are calculated from the systematic records, which are then updated by including the historical peaks and the expected moments from the historical period when no large floods occurred (below-threshold floods). The updated moments result in new estimates. The last two steps are repeated until the algorithm converges. A more rigorous and detailed explanation on EMA is given in Cohn and others (1997).

The EMA method also incorporates censored peak data into its computation. Censored data may be expressed in terms of perception thresholds that are most often used during historical periods outside the period of systematic data. For example, a site may have some historical information that indicates that a large recorded peak streamflow $\left(\mathrm{Q}_{\text {hist }}\right)$ was the largest since 1900, before any systematic data collection was started in 1930. Each annual peak from 1900 to 1929 can thus be characterized as a censored streamflow whose value is known to have not exceeded the perception threshold $\left(\mathrm{Q}_{\text {hist }}\right)$, and estimates of the bounded streamflow between 0 and $\mathrm{Q}_{\text {hist }}$ can be used in the LP3 flood-frequency analysis. The EMA method also allows the use of interval values to characterize 
peak data that are known to be greater or less than some specific value or that can only be reliably estimated within a specific range. Interval values commonly are used by the EMA method to characterize missing data during periods of systematic data. For example, if a peak streamflow or stage was not determined because the water level was below a measureable level, the missing peak data can be characterized as an interval. The interval has a range that is bounded by zero and the stage at the bottom of the gage or the streamflow associated with the stage at the bottom of the gage. Missing peaks during periods of systematic data typically are ignored when the conventional method of moments is used as in the Bulletin 17B methodology.

The EMA procedure also incorporates the censoring of multiple low outliers. The procedure for identifying multiple potentially influential low outliers in data is the multiple Grubbs-Beck (MGB) (T.A. Cohn, U.S. Geological Survey, written commun., 2013), which is described in the following section.

\section{Multiple Grubbs-Beck Test for Detecting Low Outliers}

The Grubbs-Beck test is recommended (Interagency Advisory Committee on Water Data, 1982) for detecting low outliers that can be subsequently censored so they do not have a large influence on the fitting of the upper tail (in other words, larger peak streamflows with smaller AEPs) of the LP3 distribution. The Grubbs-Beck test uses the at-site logarithms of the flood data to calculate a one-sided, 10-percent significance-level critical value for a normally distributed sample. The Grubbs-Beck test usually reports only one flood, the lowest flood, although there could be several floods with data that are below the critical value. Several streamgages had annual flood data that were substantially smaller than most of the recorded annual flood data where the Grubbs-Beck test identified only one or no low outliers for these streamgages. Thus, a method for statistically detecting multiple potentially influential low outliers using a generalized Grubbs-Beck test was developed and implemented in the EMA algorithm (Cohn, 2011). The MGB test is based on a one-sided, 10-percent significance-level critical value for a normally distributed sample, but the test is constructed so that groups of ordered data are examined (for example, the eight smallest values) and excluded from the data when the critical value is calculated. If the critical value is greater than that eighth smallest value in the sample, then all eight values are considered to be low outliers. As described by T.A. Cohn (U.S. Geological Survey, written commun., 2011), the low outliers identified by the MGB test tend to closely match user-selected low-outlier thresholds determined from plotted flood-frequency curves. Therefore, the MGB test was used for this study. A floodfrequency curve for a streamgage with 8 percent of the lower tail of the distribution identified and subsequently censored as low outliers is shown in figure 4. EMA results using a MGB

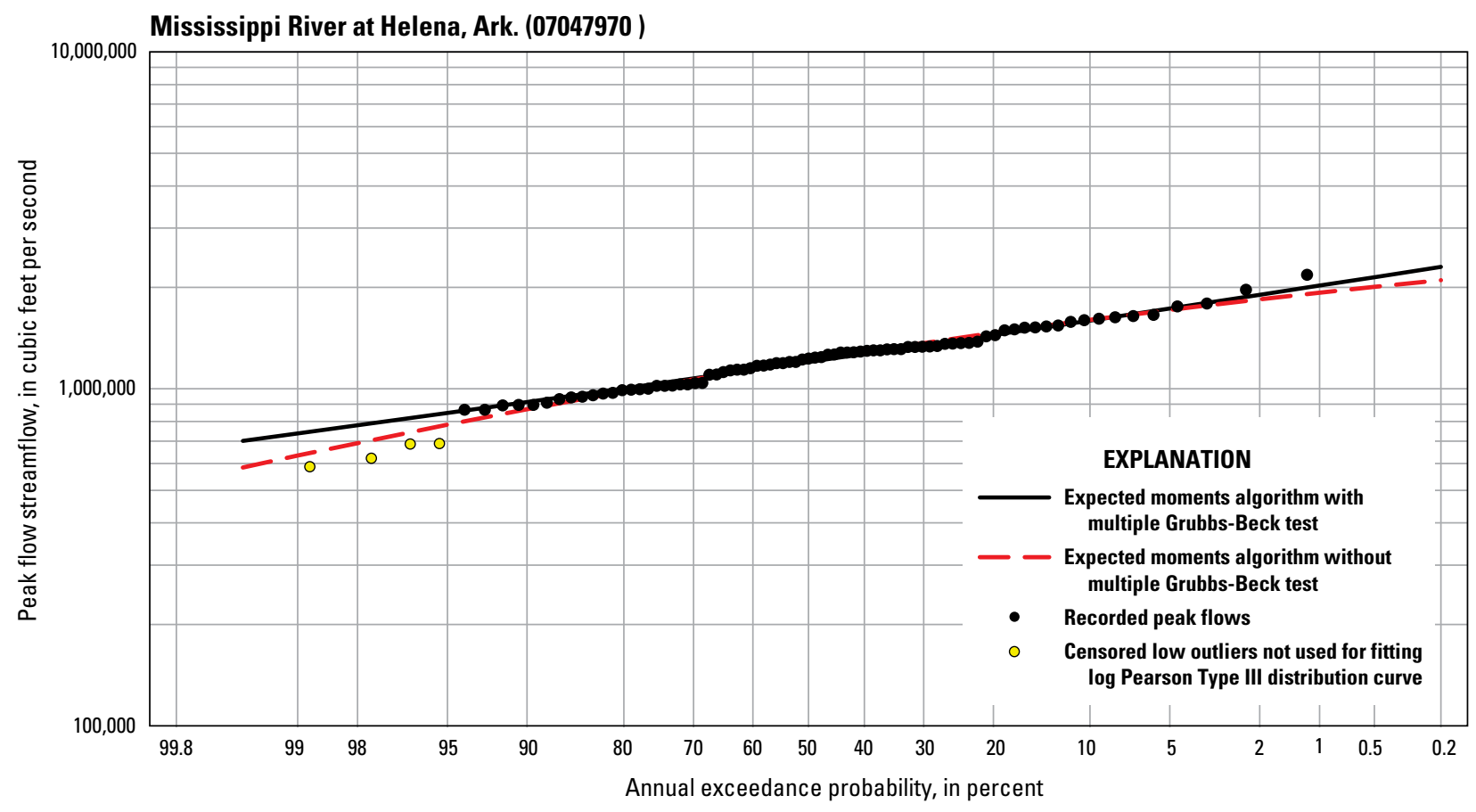

Figure 4. Log-Pearson Type III flood-frequency curves for Mississippi River at Helena, Arkansas (07047970), streamgage using the expected moments algorithm (EMA) with and without the multiple Grubbs-Beck (MGB) test for censoring low outliers. 
test were 8,11 , and 15 percent larger for the $1,0.5$, and 0.2 AEP floods, respectively, than EMA results using a standard Grubbs Beck test (fig. 4).

\section{Determining Joint Probability}

Joint probability, as used in this report, refers to the probability that locations on two paired streams simultaneously experience floods of a magnitude greater than or equal to a given annual exceedance probability, given that at least one of the streams flood with a magnitude greater than or equal to that same annual exceedance probability. For example, one might be interested in the probability of streams A and B simultaneously flooding with magnitudes greater than or equal to the 1-percent AEP flood given that either stream A or B is flooding with a magnitude greater than or equal to the 1-percent AEP flood. The joint probability of flooding of two streams in many studies is needed to determine design criteria for bridges in the potential backwater region upstream from the confluence with a second stream. If both streams peak simultaneously, a larger and potentially more expensive bridge may need to be built (because of backwater effects) than if the timing of the peaks is different for the two streams. For this study, however, information on the joint probability of flooding at paired streams can aid decision makers in understanding flood risks and make cost-effective mitigation decisions. Also, emergency managers will be able to use this information to better focus flood response and resources. Eleven streamgages were paired with the Mississippi River at Helena, Ark., streamgage (07047970) to understand the relation between coincident flooding, and because streams flowing into the Mississippi River can experience the backwater effects when flooding on the Mississippi River occurs. Each of the 11 streamgages are located on streams flowing into the Mississippi River. In many cases, high-frequency streamflow data (such as hourly or more frequent) at streamgages were not available to permit direct determination of the joint probability of flooding. Thus, the analyses were based on relations between instantaneous peak streamflows and daily mean streamflows or instantaneous peak stages and maximum daily hourly stages or maximum once daily stage observations at streamgages.

This section summarizes the methodology for determining the joint probability of flooding at paired streamgages. Both peak streamflow and peak stage were used in this analysis. The methodology for determining the joint probabilities at paired sites for this study is based on methods described by Koltun and Sherwood (1998). The methodology used in this study to calculate joint probabilities of flooding at paired sites is as follows:

1. Select the streamgage pairs. The streamgages must have at least 10 years of continuous and concurrent record of both daily mean and instantaneous peak streamflow or peak stage data.
2. Calculate flood-frequency estimates for the 39 streamgages in the study area (fig. 1) using the EMA and MGB algorithms (Cohn and others, 1997; Cohn and others, 2001; Griffis and others, 2004) because these algorithms handle censored data (high and low outliers) and historical data more accurately than the Bulletin 17B methods (Interagency Advisory Committee on Water Data, 1982).

3. For each streamgage, determine the linear relation between instantaneous peak data and daily mean data occurring on the same days. Use ordinary least-squares (OLS) regression to determine the relation-its regression coefficients (slope and intercept) and correlation coefficient (r).

4. If Pearson's $r$ is weak ( $r$ less than 0.5), this method is not appropriate and the analysis should be discontinued. The $r$ measures the strength and the direction of a linear relation between two variables (Zar, 1998). An r value of 0 indicates there is no linear relation between the two variables; whereas, an $r$ value of 1 or -1 indicates a perfect linear relation.

5. Calculate flood thresholds using the instantaneous peak flood-frequency values for the 50-percent, 10-percent, 4-percent, 2-percent, and 1-percent exceedances from step 2 and input them into the regression equation in step 3 for each streamgage. Flood thresholds represent daily mean data expected to occur on days when a specified instantaneous peak occurs.

6. Create a scatterplot of concurrent daily mean data for the paired streamgages and include flood threshold exceedances (50 percent, 10 percent, 4 percent, 2 percent, and 1 percent) for both streamgages as dashed lines on the scatterplot (figs. 5 and 6). Exclude paired values from the plot and subsequent analyses if the daily mean data at both streamgages are greater than the 50-percent flood threshold exceedance.

7. Determine the number of events and trials in each flood threshold category. A flood threshold category is defined as the area between two flood thresholds. For example, a daily mean streamflow that exceeded the streamflow for the 50-percent exceedance flood threshold but not the streamflow for the 10-percent exceedance flood threshold was categorized as being in the 50-percent exceedance category. A "trial" occurs when the value of a threshold at one or both paired streamgages exceeds a given flood threshold. An "event" occurs when the value equals or exceeds the flood threshold at both streamgages in the pair. 
8. Calculate the joint probability (JP) for each flood threshold exceedance (50 percent, 10 percent, 4 percent, 2 percent, and 1 percent AEP) by dividing the number of events by the number of trials. This ratio provides an estimate of the likelihood that the flood magnitude corresponding to a given flood threshold is equaled or exceeded at both streamgages given that the flood threshold is exceeded at least one of the two streamgages.

9. On days when the instantaneous peak data also are available, the instantaneous peak data are used preferentially to determine threshold exceedance, and so the number of events or trials may be modified to better reflect threshold exceedances. For example, suppose there were two observations in which the 50-percent flood threshold was exceeded concurrently at both streams (that is, two events) based on the daily mean streamflow. However, for one of those two observations, there was a corresponding instantaneous peak streamflow that did not exceed the 50-percent AEP flood; consequently the total number of events would be revised to one instead of two. As compared to slow rising streams, flashy streams (where streamflow or stage rises and falls quickly) may have weaker correlation between peak and daily mean data increasing the likelihood that the number of trials or events need revision. In streams where the floods rise and fall slowly (such as the Mississippi River), no adjustments typically are needed.

10. Recalculate the adjusted JP value for each threshold exceedance if the number of events and trials was revised.

\section{Collection of High-Water-Mark Data}

After floodwaters recede, HWMs can be the best available evidence of the water-surface elevations reached by the flood peak at a particular location (Benson and Dalrymple, 1967). A total of 122 HWMs along the Black, White, and Cache Rivers and near the communities of Holly Grove and Cotton Plant, Ark., were located, flagged, and surveyed by USACE and USGS field crews. The Arkansas State Highway and Transportation Department (AHTD) provided additional information on HWMs near the Interstate-40 crossing with the White River as well as stream-channel-bathymetry data for the White River. At selected USACE and USGS streamgage locations, the peak stage recorded was converted to a water-surface elevation by adding it to the respective gage datum and then referenced to the North American Vertical Datum of 1988 (NAVD 88). The quality of HWMs collected by USACE were subjectively rated in the field in order of mark confidence as "Great," "Good," "Fair," or "Poor," respectively, by USACE field personnel (Catherine Funkhouser, U.S. Army Corps of Engineers-Little Rock, written commun., 2012). The quality of HWMs collected by USGS were rated in the field based on the perceived accuracy of the mark "Excellent," "Good,"
"Fair," or "Poor" (Lumia, 1986). Details regarding the HWMs, including location, elevation, and description, are recorded in appendix 1 .

The survey of HWMs typically was completed by using a differential global positioning system (GPS) in conjunction with a real-time kinematic (RTK) system linked with a number of mobile GPS units. The HWMs were surveyed to an expected accuracy of $0.1 \mathrm{ft}$. The vertical datum used was the NAVD 88. Quality-assurance procedures (Ellison and others, 2011) included setting up the RTK-GPS base station at a high location (for example, on the roof of a municipal building or high on the valley ridge) for maximum satellite reception and radio coverage and locating a minimum of two control points that were surveyed multiple times during a given RTK deployment. The preferred method of surveying a HWM was to set the GPS unit on the HWM and directly collect the fixed-point data. If the HWM was too far above the ground to reach or safely occupy or if other factors prevented accurate measurements, then GPS elevation data were collected for an intermediate survey point a short distance away. The difference in elevation between the intermediate survey point and the desired HWM was later measured by means of total station survey equipment.

\section{Inundation Map Development}

Inundation maps were produced by use of a geographic information system (GIS) and associated geoprocessing modules provided by the USGS Illinois Water Science Center (Jennifer Sharpe, U.S. Geological Survey, written commun., 2012). These maps show the maximum extent and depth of the floodwaters as compared against the highest resolution of digital elevation model data available. Measured locations and elevations of HWMs were used to develop flood-peak cross sections. Cross sections were drawn through the location of the HWM perpendicular to the direction of streamflow and assigned with the elevation of the HWM. Cross sections also were drawn at selected streamgage locations based on the peak stage recorded during the flooding event. Each cross section was drawn with a wide lateral extent to ensure all areas with a terrain elevation lower than the corresponding HWM data were included between each upstream and downstream cross section. The maximum measurable elevation of the streamgage for the Beaver Dam Tailwater near Eureka Springs, Ark., was exceeded; therefore, the actual peak stage was higher than the recorded value at this location $(953.00 \mathrm{ft})$ (Steve Bays, U.S. Army Corps of Engineers-Little Rock, written commun., 2012).

A GIS application (Esri, Inc., 2010) was used to create a triangular irregular network (TIN) to represent a continuous surface of the flood-peak water-surface elevations from the HWM cross-section data. The reason for creating a TIN surface was because it can be created to match the exact water-surface elevation specified at each cross-section location. Water-surface elevations between cross sections were determined from distance-based linear interpolations 


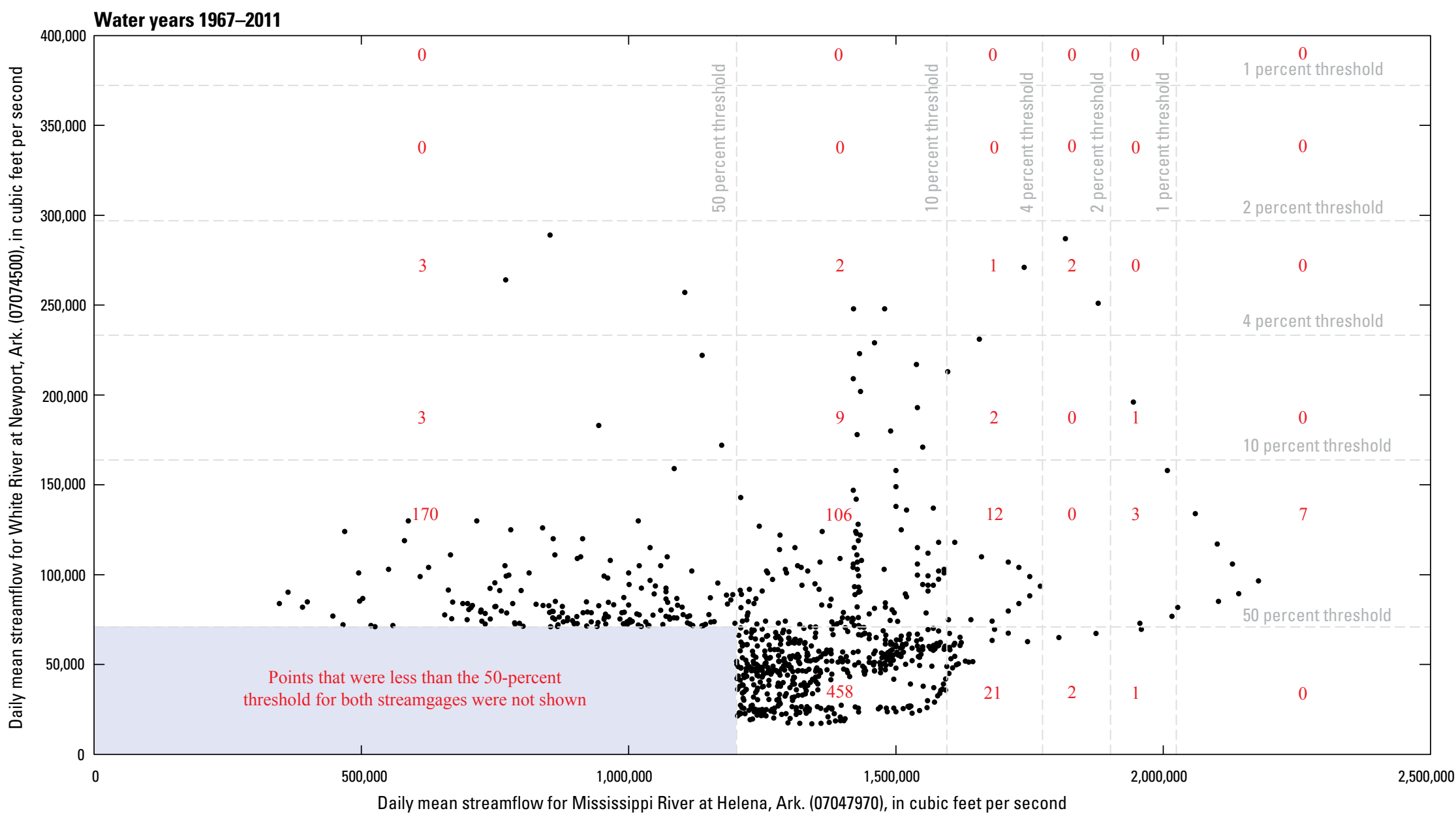

A water year is the 12-month period October 1 through September 30 designated by the calendar year in which it ends Numbers in red represent total number of points contained within each grid cell

Figure 5. Concurrent daily mean streamflow for the Mississippi River at Helena, Arkansas (07047970), and daily mean streamflow for the White River at Newport, Ark. (07074500). 


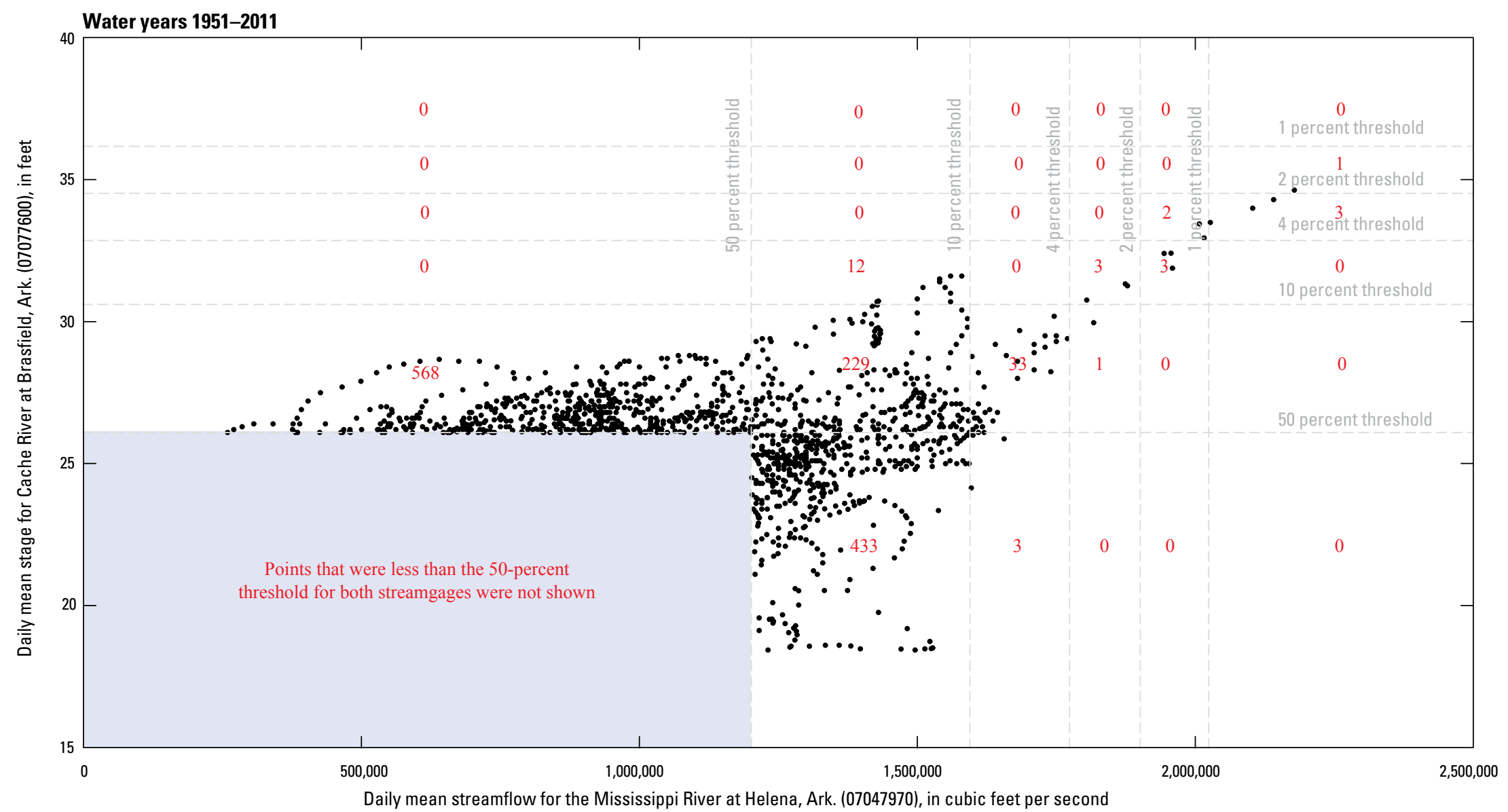

A water year is the 12-month period October 1 through September 30 designated by the calendar year in which it ends Numbers in red represent total number of points contained within each grid cell 
of the HWM data and resulted in a decreasing continuous flood surface sloping in the downstream direction. Potentially inundated areas were identified by comparing the TIN watersurface elevations to the land-surface (terrain) elevations (terrain elevation data described in more detail in the following section). Inundation areas were classified where the TIN water-surface elevations exceeded the terrain elevations. The extent of the TIN surface was derived from the cross sections, and if known areas of inundations were not identified during the comparison, cross sections were extended to produce a TIN surface, which covered a wider area.

Once potential inundation areas were identified from the comparison, all nonhydraulically connected areas (such as low-lying areas outside unbreached levees) were removed. The extent of inundation is only representative of the peak that occurred along the principal stream for which HWMs were collected. Therefore, the extent of the inundation does not necessarily correlate with the potential flooding that may have occurred on smaller tributaries. The inundation area determined for the Black River from Corning to Pocahontas was modified in Clay County, Ark., by removing inundation areas on the left bank of the stream that were protected by levees. These levees were not breached, and their spatial extents were represented in the terrain data (Elmo Webb and Catherine Funkhouser, U.S. Army Corps of Engineers-Little Rock, written commun., 2011). No changes were made to the inundation areas northwest of the levees on the Black River because Highway 62 was overtopped near Corning, Ark., allowing floodwaters to flow around the right bank side of the levees. The Black River breached 13 locations on the levees near Pocahontas, Ark., and 4 locations on the levees near Cord, Ark. (Elmo Webb and Catherine Funkhouser, U.S. Army Corps of Engineers-Little Rock, written commun., 2011). The inundation areas were left in the map near the breached levees. Along the White River in southern Jackson, Woodruff, and northern Prairie Counties, multiple levees protected lands to the east of the White River, and the generated flood surfaces in those locations were removed. The resolution of the digital terrain used in this area was not good enough to accurately represent the elevation of all mapped levees. Aerial photographs of the inundation along the White and Black Rivers in eastern Arkansas provided by the National Weather Service (Tabitha Clarke, National Weather Service, written commun., 2012) aided in the checking of inundation areas, where available.

The presence and locations of collected HWMs governed the upstream/downstream limits and accuracy of each inundation map. The extent of the inundation areas shown for tributaries was limited by where it could no longer be reasonably estimated from the HWMs or known flooded areas. For example, Village Creek, a tributary of the White River, was flooded. Its road crossings were reported closed by AHTD at two locations in Newport, Ark.: at State Highway 384 and at the Highway 18 spur from Highway 67. However, the mapped inundation area was ended at State Highway 384 at Newport, approximately $1.8 \mathrm{mi}$ to the south of the
Highway 18 spur because the lack of upstream HWMs caused uncertainty in the water-surface elevations. The Little Red River was mapped from Searcy, Ark., to its confluence with the White River because HWM data were available. Inundated areas on the White River were not shown on the Cache River maps, and inundated areas on the Cache River were not shown on the White River maps in order to highlight the flooding of each river. "Limit of the study area" lines were added to the inundation maps to help differentiate between the extent of inundation and areas not mapped.

The inundation maps were produced with a GIS gridded format file that contained the data for the maximum flood extent and depth. This format allows the maps to be overlain upon other maps and orthophotographs and to be imported into various GIS applications. All figures were generated with the GIS files overlaid on 2010 imagery from the National Agriculture Imagery Program (2010).

\section{Terrain Elevation Data}

Light detection and ranging (lidar)-based data were used to generate highly accurate three-dimensional raster grid representations of the terrain elevation. The lidar data were processed according to the USGS National Elevation Program lidar specifications (Heidemann, 2012), which included hydro-flattening to a 2 -ft contour accuracy and a vertical accuracy of 7.3 in. (William Penn, U.S. Army Corps of Engineers-Little Rock, written commun., 2012). The lidar derived raster grids were obtained from the USACE-LR (William Penn, U.S. Army Corps of Engineers-Little Rock, written commun., 2012).The lidar derived raster grids (hereafter referred to as lidar raster grids) had a minimum horizontal resolution of $3.28 \mathrm{ft}$ and elevation values were in feet. The lidar raster grids were used as the terrain elevation data, where available, but otherwise, a 10-meter (m) raster digital elevation model (DEM) from the National Elevation Dataset (NED) was used (table 3; Gesch, 2007; Gesch and others, 2002). NED is available for the conterminous United States at a $1 / 3$-arc second $(10 \mathrm{~m})$ horizontal resolution, an overall absolute vertical accuracy expressed as the root mean square error of $8.00 \mathrm{ft}$, and a mean relative vertical accuracy of $5.4 \mathrm{ft}$ (Gesch, 2007). NED data were converted from meters to feet, and when used in conjunction with lidar raster grid data, the NED was resampled to match the horizontal resolution of the appropriate lidar raster grid. In some areas, lidar and the NED data were mosaicked (merged) into one DEM to cover the entire study area and facilitate the use of the best available data (table 3). Finally, the DEM data were edited to include levee location and corresponding elevations provided by the USACE-LR (Elmo Webb and Catherine Funkhouser, U.S. Army Corps of Engineers-Little Rock District, written commun., 2011). AHTD provided bathymetry and survey data for area of the Interstate- 40 crossing with the White River that was used to further refine the DEM (Brooks Booher, Arkansas Highway Transportation Department, written commun., 2012). 
Table 3. Sources and resolution for the digital elevation models (DEMs) used for inundation mapping.

[Ark., Arkansas; lidar, Light Detection And Ranging; m, meter; NED, National Elevation Dataset; ft, feet; AHTD, Arkansas State Highway and Transportation Department; Mo., Missouri]

\begin{tabular}{|c|c|}
\hline Inundation stream reach & Terrain data and horizontal resolution \\
\hline White River from Batesville to Newport, Ark. & $3 \mathrm{ft}$ lidar derived raster grids ${ }^{1}$ merged with $10 \mathrm{~m}$ raster from $\mathrm{NED}^{2}$ \\
\hline White River from Newport to Des Arc, Ark. & $3.28 \mathrm{ft}$ lidar derived raster grids ${ }^{1}$, merged with $10 \mathrm{~m} \mathrm{NED}^{2}$ \\
\hline $\begin{array}{l}\text { Black River from Pocahontas to the confluence with the White } \\
\text { River near Newport, Ark. }\end{array}$ & $3 \mathrm{ft}$ lidar derived raster grids ${ }^{1}$ merged with $10 \mathrm{~m}$ raster from $\mathrm{NED}^{2}$ \\
\hline $\begin{array}{l}\text { Holly Grove, Ark., adjacent to a tributary of the White River, } \\
\text { Maddox Bay }\end{array}$ & $10 \mathrm{~m}$ raster from $\mathrm{NED}^{2}$ \\
\hline Cotton Plant, Ark., adjacent to the Cache River & $10 \mathrm{~m}$ raster from $\mathrm{NED}^{2}$ \\
\hline Interstate- 40 crossing with the White River, Ark. & $\begin{array}{l}\text { AHTD land survey and bathymetry data }{ }^{3} \text { merged with } 10 \mathrm{~m} \text { raster } \\
\text { from } \mathrm{NED}^{2}\end{array}$ \\
\hline White River at Beaver Dam Tailwater near Eureka Springs, Ark. & $3 \mathrm{ft}$ lidar derived raster grids ${ }^{1}$ \\
\hline White River at Table Rock Dam Tailwater near Branson, Mo. & $3 \mathrm{ft}$ lidar derived raster grids ${ }^{1}$ merged with $10 \mathrm{~m}$ raster from $\mathrm{NED}^{2}$ \\
\hline
\end{tabular}

${ }^{1}$ Lidar derived raster grids were obtained from William Penn, U.S. Army Corps of Engineers-Little Rock District, written commun. (2012).

${ }^{2} 10$-m raster NED (Gesch, 2007; Gesch and others, 2002).

${ }^{3}$ Land survey and bathymetry data were obtained from Brooks Booher, Arkansas Highway Transportation Department, written commun. (2012).

\section{Uncertainty in Flood-Peak Inundation Maps}

The accuracy of inundation mapping was a function of the amount and accuracy of available HWM data and the accuracy of the DEM. Generally when hydraulic models are used to develop inundation maps, the largest source of uncertainty is associated with the terrain data (Bales and Wagner, 2009; Merwade and others, 2008; Werner, 2001). However, provided the methods used in this particular study, a greater source of error may be related to the interpolation of the water-surface elevation between HWMs. HWMs were collected throughout the study area as discrete point measurements from a few feet to several miles apart, therefore, the water-surface elevations between HWMs were interpolated by a TIN algorithm. This process of interpolation between HWMs assumed changes in the water-surface elevations were gradual between collected HWMs; however, this assumption may not have been an accurate representation of the watersurface elevations at every location. The assumption was based on several factors: streams have uniform and gentle sloping channels, streamflow rises and falls slowly, and contributions from tributaries between HWMs were minor in comparison to the overall streamflow. The error associated with water-surface elevation interpolations is difficult to quantify given the available data and therefore would be hard to ascertain if the interpolation of the water surface caused more uncertainty compared to the terrain data. As previously mentioned, in some cases, high resolution lidar raster data were mosaicked with a lower resolution 10-m raster from the NED. The NED data have less horizontal and vertical accuracy compared to the lidar raster data; therefore, the uncertainty is greater in areas where inundation maps were derived from NED data. Inundation depths derived from lidar are displayed at a finer resolution than those generated from the NED. Also, water depths in the stream channel are only estimates because traditional infrared lidar cannot penetrate water and will inaccurately represent stream-channel depths in water-filled channels.

Inaccuracies in HWM elevations can occur if evidence of the true flood peak has degraded by the time data were collected. Thirty-eight HWMs were collected near the Interstate- 40 crossing with the White River. The AHTD collected HWMs on and around the interstate and its embankments in May 2011. USGS survey crews collected additional HWMs upstream and downstream from the interstate crossing at two different periods after the flood occurred. The first period was in November 2011 and the second was in March 2012. This area floods frequently and HWM identification was difficult after the delay. As a result, some HWMs were not used for the Interstate- 40 crossing with the White River map because their elevations were inconsistent with respect to the majority of the HWMs. For example, HWMs I-40LDN03, I-40LDN04, I-40LDN05, I-40LDN06, I-40HWMDN1, and I-40HWMDN2 were not used because they were from a smaller event or were an artifact of slowly receding floodwaters. The collection of HWMs for the communities of Holly Grove and Cotton Plant occurred during November 2011, more than 6 months after the flood event. Normal indicators of high water such as seed lines, mudlines, and debris lines were difficult to find because of cleanup or weathering. Consequentially, the resulting inundation maps for Holly Grove, Cotton Plant, and Interstate-40 crossing with the White River have more uncertainty than the other maps where HWMs were 
determined soon after the flooding. In spite of these issues, every effort was made to ensure a close approximation of the true flood-inundation characteristics.

\section{Disclaimer for Flood-Peak Inundation Maps}

Inundated areas and depths are only an estimate of flooding that occurred during the April-May 2011 flooding event in northern and eastern Arkansas and southern Missouri. Because unique meteorological and hydrological conditions preceded this flood, these inundation maps should not be used for navigation, regulatory, permitting, or other legal purposes. These maps are to be used as an estimated flood-peak surface for a specific flooding event. The USGS provides these maps "as-is" for a quick reference, emergency planning tool but assumes no legal liability or responsibility resulting from the use of this information.

\section{Flood Analysis and Inundation Mapping for the Flood of April-May 2011 in Northern and Eastern Arkansas and Southern Missouri}

The magnitudes, estimated annual exceedance probabilities, and joint probabilities of peak streamflows for the April-May 2011 flood are presented in this section of the report. Inundation maps showing maximum flood extent and water depths also are presented.

\section{Magnitudes and Estimated Flood Frequencies of Peak Streamflows}

Peak stages and peak streamflows were tabulated for 39 USGS and USACE streamgages (table 4), and annual exceedance probabilities are presented for 37 of those streamgages (table 5). Locations of streamgages are shown in figures 1 and 3. For the period of record used in this report, peak-of-record stage occurred at 24 of the 39 streamgages, and peak-of-record streamflow occurred at 13 of the 30 streamgages where streamflow was determined (table 5). Annual exceedance probabilities of flooding were computed for the 37 streamgages at the 50-, 20-, 10-, 4-, 2-, 1-, 0.5-, and 0.2-percent AEP (table 5). For the streamgages not in backwater, the stage or streamflow recorded from the April-May 2011 flood were assigned annual exceedance probabilities. Annual exceedance probabilities were estimated to be less than 0.2 percent (recurrence interval greater than 500 years) at one streamgage, St. Francis River at Wappapello, Mo. Annual exceedance probabilities were less than 0.5 percent (recurrence interval greater than 200 years) at 3 streamgages, both Mississippi River streamgages at Memphis, Tenn., and Helena, Ark., and the White River near Augusta, Ark.; less than 1 percent (recurrence interval greater than 100 years) at 6 streamgages; less than 2 percent (recurrence interval greater than 50 years) at 12 streamgages; and the remaining 14 streamgages were 4 percent or greater (recurrence interval less than 25 years). The final flood frequencies for a range of corresponding annual exceedance probabilities for the 37 streamgages are provided in table 5 .

Table 4. Site information for U.S. Geological Survey streamgage stations within the study area for water year 2011.

$\left[\mathrm{ft}^{3} / \mathrm{s}\right.$, cubic feet per second; ft, feet; $\mathrm{mi}^{2}$, square mile; Okla., Oklahoma; Ark, Arkansas; Mo, Missouri; Tenn., Tennessee; A water year is the 12-month period October 1 through September 30 designated by the calendar year in which it ends; Vertical coordinate data are referenced to the North American Vertical Datum of 1988 (NAVD 88)]

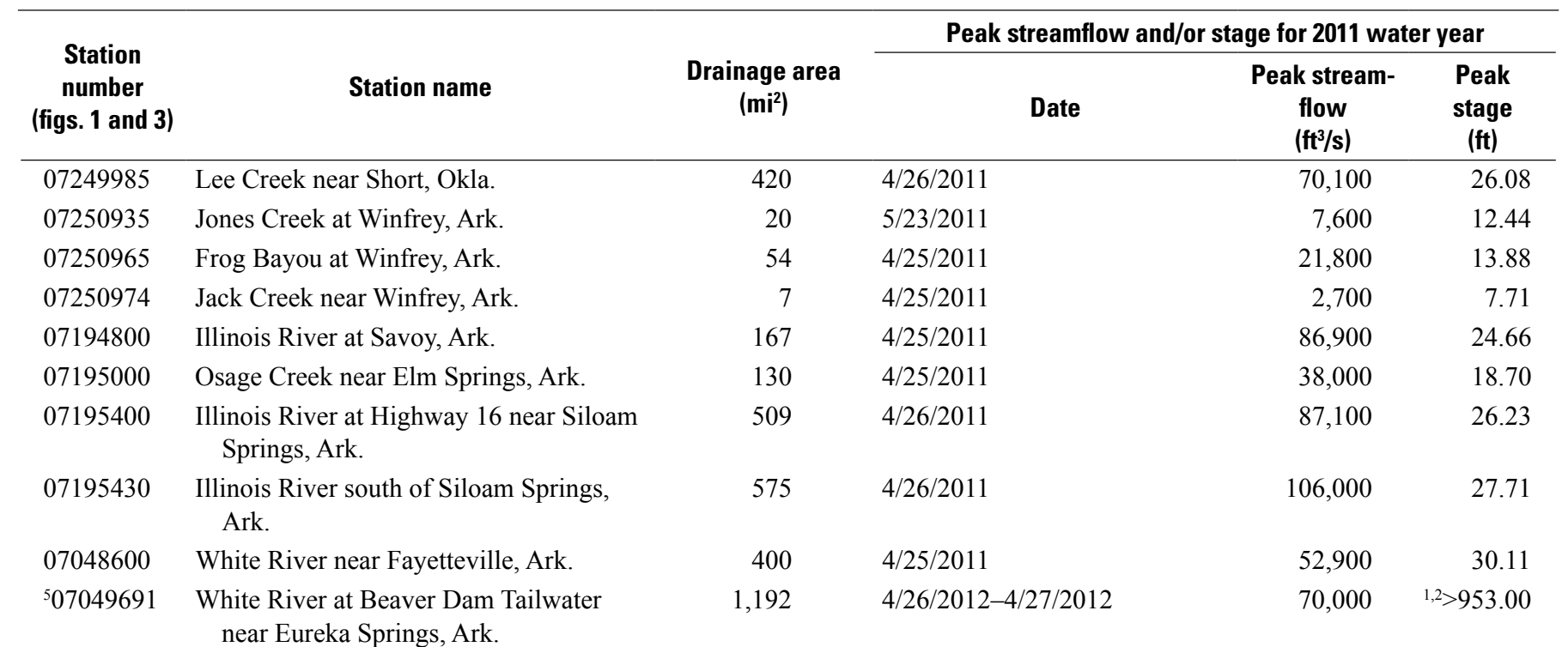


Table 4. Site information for U.S. Geological Survey streamgage stations within the study area for water year 2011.—Continued

$\left[\mathrm{ft}^{3} / \mathrm{s}\right.$, cubic feet per second; ft, feet; $\mathrm{mi}^{2}$, square mile; Okla., Oklahoma; Ark, Arkansas; Mo, Missouri; Tenn., Tennessee; A water year is the 12-month period October 1 through September 30 designated by the calendar year in which it ends; Vertical coordinate data are referenced to the North American Vertical Datum of 1988 (NAVD 88)]

\begin{tabular}{|c|c|c|c|c|c|}
\hline \multirow[b]{2}{*}{$\begin{array}{c}\text { Station } \\
\text { number } \\
\text { (figs. } 1 \text { and } 3 \text { ) }\end{array}$} & \multirow[b]{2}{*}{ Station name } & \multirow[b]{2}{*}{$\begin{array}{l}\text { Drainage area } \\
\qquad\left(\mathrm{mi}^{2}\right)\end{array}$} & \multicolumn{3}{|c|}{ Peak streamflow and/or stage for 2011 water year } \\
\hline & & & Date & $\begin{array}{l}\text { Peak stream- } \\
\text { flow } \\
\left(\mathrm{ft}^{3} / \mathrm{s}\right)\end{array}$ & $\begin{array}{l}\text { Peak } \\
\text { stage } \\
\text { (ft) }\end{array}$ \\
\hline${ }^{5} 07053401$ & $\begin{array}{l}\text { White River at Table Rock Dam } \\
\text { Tailwater near Branson, Mo. }\end{array}$ & 34,020 & $4 / 27 / 2011$ & 69,000 & 1727.86 \\
\hline${ }^{5} 07054501$ & $\begin{array}{l}\text { White River at Bull Shoals Dam } \\
\text { Tailwater near Flippin, Ark. }\end{array}$ & 6,050 & $5 / 26 / 2011$ & 53,000 & ${ }^{1} 468.73$ \\
\hline 07074500 & White River at Newport, Ark. & 19,900 & $5 / 4 / 2011$ & 292,000 & 34.17 \\
\hline 07074850 & White River near Augusta, Ark. & 20,500 & $5 / 5 / 2011$ & 262,000 & 40.70 \\
\hline 07076750 & White River near Georgetown, Ark. & 22,400 & $5 / 6 / 2011$ & Backwater & 33.95 \\
\hline 07076900 & White River at Des Arc, Ark. & 22,111 & $5 / 6 / 2011$ & Backwater & 39.43 \\
\hline 07077000 & White River at De Valls Bluff, Ark. & 23,400 & $5 / 7 / 2011$ & Backwater & 36.10 \\
\hline 07062500 & Black River at Leeper, Mo. & 987 & $4 / 24 / 2011$ & 11,700 & 12.98 \\
\hline 07062575 & Black River above Williamsville, Mo. & 1,007 & $4 / 24 / 2011$ & 31,000 & 17.69 \\
\hline 07063000 & Black River at Poplar Bluff, Mo. & 1,245 & $4 / 26 / 2011$ & 24,400 & 21.41 \\
\hline 07064000 & Black River near Corning, Ark. & 1,750 & $4 / 28 / 2011$ & 40,700 & 18.12 \\
\hline 07069000 & Black River at Pocahontas, Ark. & 4,840 & $4 / 28 / 2011$ & 86,600 & 28.44 \\
\hline 07072500 & Black River at Black Rock, Ark. & 7,370 & $4 / 26 / 2011$ & 172,000 & 30.45 \\
\hline 07074420 & Black River at Elgin Ferry, Ark. & 8,420 & $\begin{array}{l}4 / 28 / 2011 \text { for the peak } \\
\text { streamflow } 5 / 4 / 2011 \text { for the } \\
\text { peak stage and affected by } \\
\text { backwater }\end{array}$ & 212,000 & 34.77 \\
\hline${ }^{6} 07040100$ & St. Francis River at St. Francis, Ark. & 1,770 & $5 / 3 / 2011$ & 27,000 & 27.25 \\
\hline${ }^{6} 07040450$ & St. Francis River at Lake City, Ark. & 2,370 & $5 / 3 / 2011$ & 42,600 & 14.37 \\
\hline${ }^{6} 07047800$ & St. Francis River at Parkin, Ark. & $\begin{array}{l}\text { Drainage area not } \\
\text { determined }\end{array}$ & $5 / 6 / 2011$ & 24,000 & 28.08 \\
\hline${ }^{6} 07047907$ & St. Francis River at Madison, Ark. & $\begin{array}{l}\text { Drainage area not } \\
\text { determined }\end{array}$ & $5 / 13 / 2011$ & Not available & 39.81 \\
\hline${ }^{6} 07032000$ & Mississippi River at Memphis, Tenn. & 932,800 & $\begin{array}{l}5 / 9 / 2011-5 / 10 / 2011 \text { for the } \\
\text { peak streamflow } 5 / 10 / 2011 \\
\text { for the peak stage }\end{array}$ & $2,190,000$ & 48.03 \\
\hline${ }^{6} 07047970$ & Mississippi River at Helena, Ark. & ${ }^{4} 939,300$ & $5 / 11 / 2011$ & $2,180,000$ & 56.59 \\
\hline
\end{tabular}

${ }^{1}$ Peak water-surface elevation (feet above NAVD 88).

${ }^{2}$ Water-surface elevation exceeded maximum recordable level of $953.00 \mathrm{ft}$.

${ }^{3}$ Drainage area from U.S. Army Corps of Engineers (2011b).

${ }^{4}$ Drainage area from Moore and Frankenfield (1905).

${ }^{5}$ Streamgage operated by the U.S. Army Corps of Engineers-Little Rock District.

${ }^{6}$ Streamgage operated by the U.S. Army Corps of Engineers-Memphis District. 
Table 5. Flood-frequency analysis for selected streamgages.

[Annual exceedance probabilities were estimated to be minimally less than number in bold for the April-May $2011 \mathrm{flood}$; $\mathrm{ft}^{3} / \mathrm{s}$, cubic feet per second; ft, feet; A water year is the 12-month period October 1 through September 30 designated by the calendar year in which it ends; Ark., Arkansas; Mo., Missouri; Tenn., Tennessee; Okla., Oklahoma; AEP, annual exceedance probability; NAVD 88, North American Vertical Datum of 1988]

\begin{tabular}{|c|c|c|c|c|c|}
\hline $\begin{array}{c}\text { Station } \\
\text { number } \\
\text { (figs. } 1 \text { and } 3 \text { ) }\end{array}$ & Station name & $\begin{array}{c}2011 \text { Peak } \\
\text { streamflow } \\
\left(\mathrm{ft}^{3} / \mathrm{s}\right)\end{array}$ & $\begin{array}{l}2011 \text { Peak } \\
\text { stage } \\
\text { (ft) }\end{array}$ & $\begin{array}{l}\text { Period of record } \\
\text { used in report } \\
\text { (water year) }\end{array}$ & $\begin{array}{c}\text { Data type } \\
\text { used for esti- } \\
\text { mating AEP }\end{array}$ \\
\hline 07249985 & Lee Creek near Short, Okla. & 70,100 & 26.08 & $1993-2011$ & Streamflow \\
\hline \multicolumn{6}{|c|}{ Frog Bayou } \\
\hline 07250965 & Frog Bayou at Winfrey, Ark. & 121,800 & ${ }^{2} 13.88$ & $2003-11$ & Streamflow \\
\hline 07250974 & $\begin{array}{l}\text { Jack Creek near Winfrey, } \\
\text { Ark. }\end{array}$ & 2,700 & 7.71 & $2002-11$ & Streamflow \\
\hline \multicolumn{6}{|c|}{ Illinois River } \\
\hline 07195400 & $\begin{array}{l}\text { Illinois River at Hwy. } 16 \text { near } \\
\text { Siloam Springs, Ark. }\end{array}$ & ${ }^{1} 87,100$ & ${ }^{2} 26.23$ & $1980-81,1986,2003-11$ & Streamflow \\
\hline 07195430 & $\begin{array}{l}\text { Illinois River south of Siloam } \\
\text { Springs, Ark. }\end{array}$ & ${ }^{1} 106,000$ & 227.71 & $1996-2011$ & Streamflow \\
\hline \multicolumn{6}{|c|}{ White River } \\
\hline 07048600 & $\begin{array}{l}\text { White River near Fayetteville, } \\
\text { Ark. }\end{array}$ & 52,900 & 30.11 & 1964-2011 & Streamflow \\
\hline 07053401 & $\begin{array}{l}\text { White River at Table Rock } \\
\text { Dam Tailwater near } \\
\text { Branson, Mo. }\end{array}$ & 69,000 & $2,6727.86$ & $1988-2011$ & Stage $^{3}$ \\
\hline 07076750 & $\begin{array}{l}\text { White River near Georgetown, } \\
\text { Ark. }\end{array}$ & Backwater & 233.95 & $1967-2011$ & Stage $^{4}$ \\
\hline 07076900 & $\begin{array}{l}\text { White River at Des Arc, } \\
\text { Ark. }\end{array}$ & Backwater & 239.43 & $1967-81,1984-91,1995-2001,2005-11$ & Stage $^{5}$ \\
\hline 07077000 & $\begin{array}{l}\text { White River at De Valls Bluff, } \\
\text { Ark. }\end{array}$ & Backwater & 236.10 & $1967-70,1989-2011$ & Stage \\
\hline 07077800 & $\begin{array}{l}\text { White River at Clarendon, } \\
\text { Ark. }\end{array}$ & Backwater & 237.54 & $1967-2011$ & Stage $^{4}$ \\
\hline 07077820 & $\begin{array}{l}\text { White River at St. Charles, } \\
\text { Ark. }\end{array}$ & Backwater & ${ }^{2} 39.99$ & $1967-80,1982-90,1992-2000,2002-11$ & Stage $^{4}$ \\
\hline \multicolumn{6}{|c|}{ Black River } \\
\hline 07062050 & $\begin{array}{l}\text { Black River at Clearwater } \\
\text { Dam Tailwater near } \\
\text { Piedmont, Mo. }\end{array}$ & 4,258 & 58.42 & 1991-2011 & Streamflow \\
\hline
\end{tabular}


Table 5. Flood-frequency analysis for selected streamgages.-Continued

[Annual exceedance probabilities were estimated to be minimally less than number in bold for the April-May $2011 \mathrm{flood}$; $\mathrm{ft}^{3} / \mathrm{s}$, cubic feet per second; ft, feet; A water year is the 12-month period October 1 through September 30 designated by the calendar year in which it ends; Ark., Arkansas; Mo., Missouri; Tenn., Tennessee; Okla., Oklahoma; AEP, annual exceedance probability; NAVD 88, North American Vertical Datum of 1988]

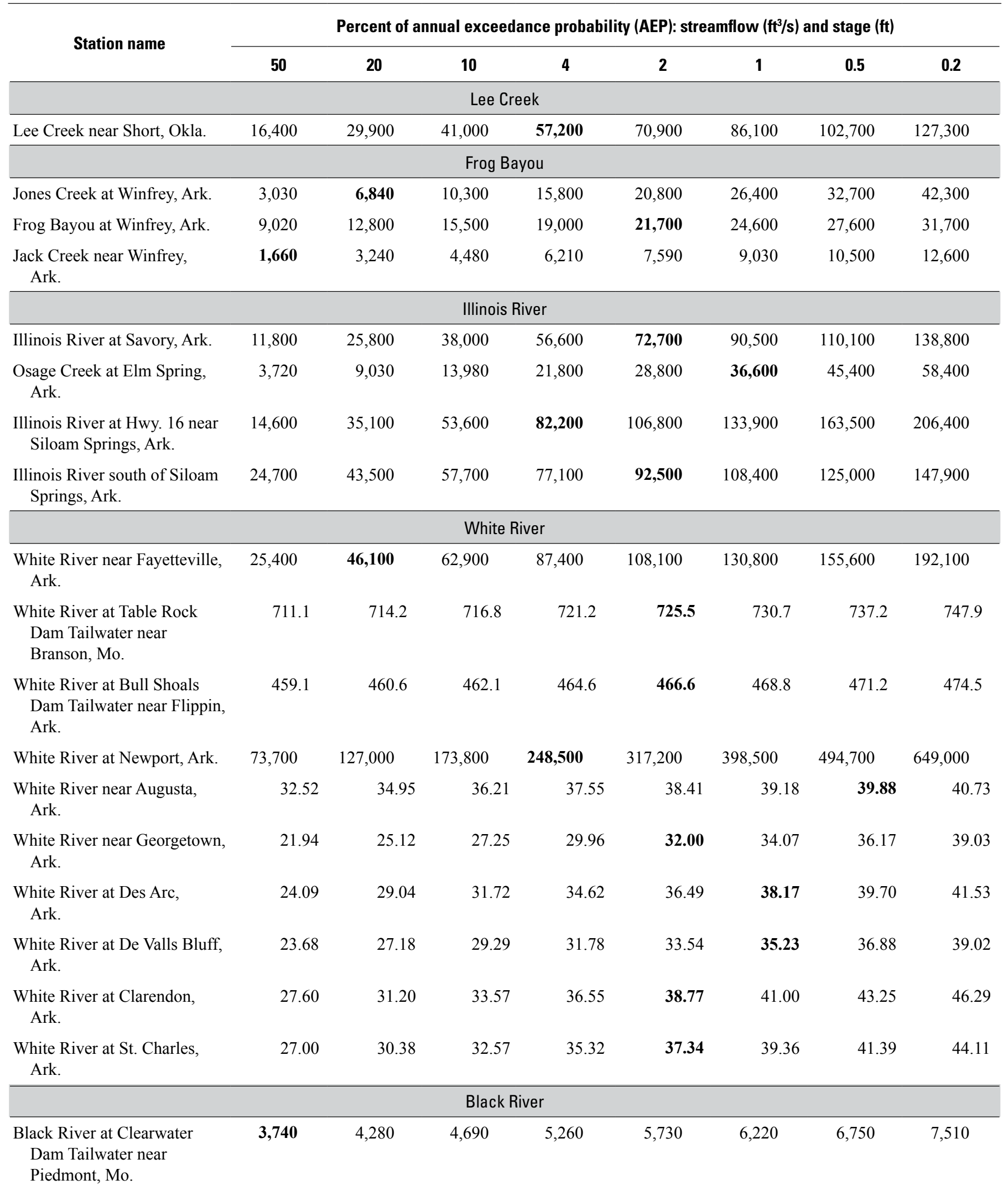


Table 5. Flood-frequency analysis for selected streamgages.-Continued

[Annual exceedance probabilities were estimated to be minimally less than number in bold for the April-May $2011 \mathrm{flood}$; $\mathrm{ft}^{3} / \mathrm{s}$, cubic feet per second; ft, feet; A water year is the 12-month period October 1 through September 30 designated by the calendar year in which it ends; Ark., Arkansas; Mo., Missouri; Tenn., Tennessee; Okla., Oklahoma; AEP, annual exceedance probability; NAVD 88, North American Vertical Datum of 1988]

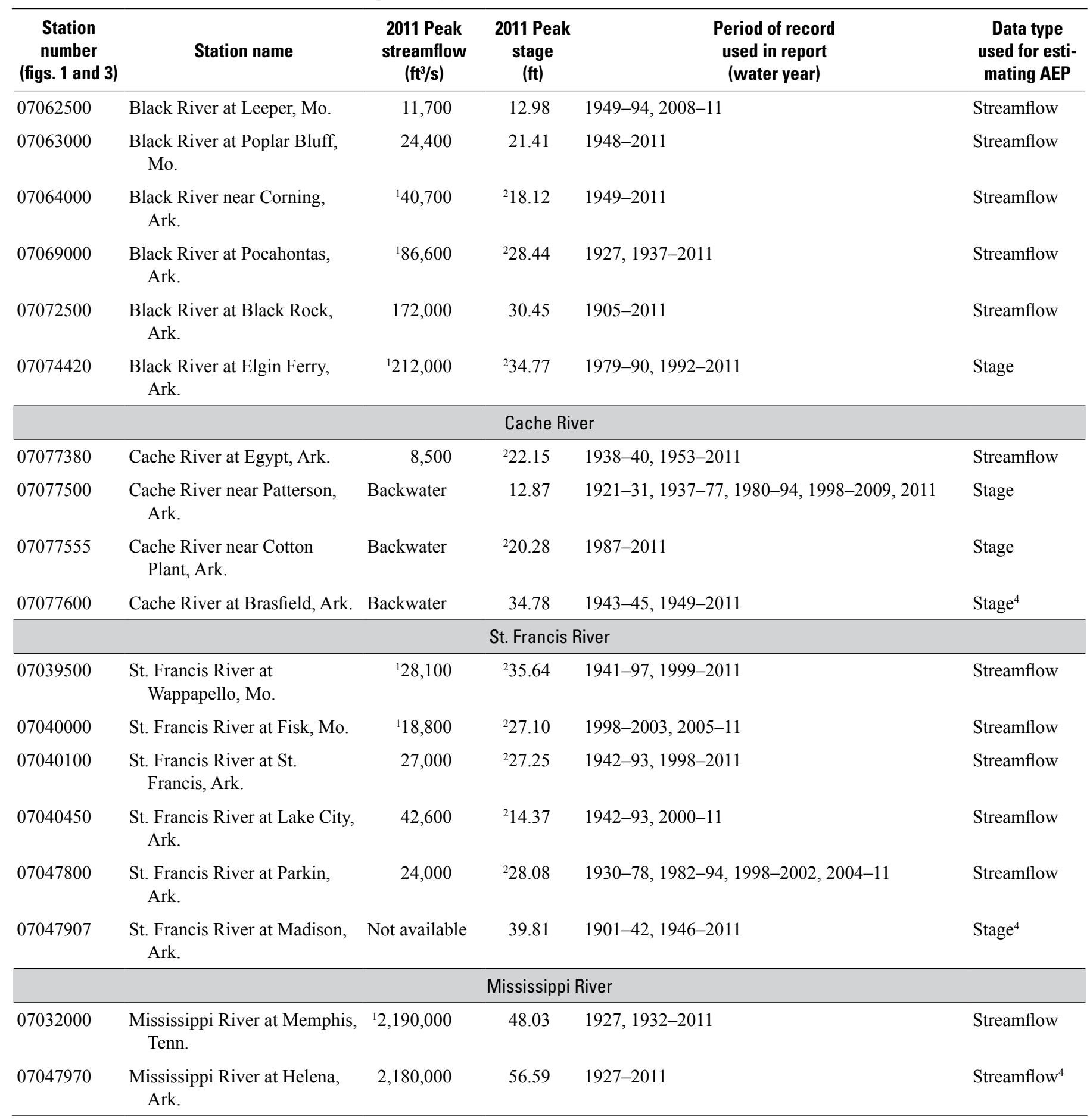

${ }^{1}$ Peak-of-record streamflow for period of record used in report.

${ }^{2}$ Peak-of-record stage for period of record used in report.

${ }^{3}$ Annual peak data are based on a daily maximum of hourly readings.

${ }^{4}$ Annual peak data are based on a single reading per day.

${ }^{5}$ Annual peak data are based on a single reading per day for water years 1981 through 2011.

${ }^{6}$ Peak water-surface elevation (feet above NAVD 88). 
Table 5. Flood-frequency analysis for selected streamgages.-Continued

[Annual exceedance probabilities were estimated to be minimally less than number in bold for the April-May $2011 \mathrm{flood}$; $\mathrm{ft}^{3} / \mathrm{s}$, cubic feet per second; $\mathrm{ft}$, feet; A water year is the 12-month period October 1 through September 30 designated by the calendar year in which it ends; Ark., Arkansas; Mo., Missouri; Tenn., Tennessee; Okla., Oklahoma; AEP, annual exceedance probability; NAVD 88, North American Vertical Datum of 1988]

\begin{tabular}{|c|c|c|c|c|c|c|c|c|}
\hline \multirow{2}{*}{ Station name } & \multicolumn{8}{|c|}{ Percent of annual exceedance probability (AEP): streamflow ( $\left.\mathrm{ft}^{3} / \mathrm{s}\right)$ and stage (ft) } \\
\hline & 50 & 20 & 10 & 4 & 2 & 1 & 0.5 & 0.2 \\
\hline $\begin{array}{l}\text { Black River at Poplar Bluff, } \\
\text { Mo. }\end{array}$ & 7,250 & 12,600 & 17,800 & 26,800 & 35,900 & 47,500 & 62,300 & 88,100 \\
\hline $\begin{array}{l}\text { Black River at Pocahontas, } \\
\text { Ark. }\end{array}$ & 24,100 & 42,100 & 54,900 & 71,600 & 84,100 & 96,500 & 108,900 & 125,300 \\
\hline $\begin{array}{l}\text { Black River at Black Rock, } \\
\text { Ark. }\end{array}$ & 41,900 & 69,400 & 90,900 & 122,100 & 148,100 & 176,600 & 207,900 & 253,800 \\
\hline Cache River at Egypt, Ark. & 4,510 & 5,790 & 6,640 & 7,700 & 8,490 & 9,290 & 10,090 & 11,200 \\
\hline $\begin{array}{l}\text { Cache River near Patterson, } \\
\text { Ark. }\end{array}$ & 10.50 & 11.55 & 12.25 & 13.12 & 13.77 & 14.42 & 15.07 & 15.94 \\
\hline $\begin{array}{l}\text { Cache River near Cotton } \\
\text { Plant, Ark. }\end{array}$ & 19.32 & 19.95 & 20.22 & 20.47 & 20.62 & 20.73 & 20.82 & 20.92 \\
\hline Cache River at Brasfield, Ark. & 26.09 & 28.31 & 30.60 & 32.85 & 34.52 & 36.18 & 37.86 & 40.10 \\
\hline \multicolumn{9}{|c|}{ St. Francis River } \\
\hline $\begin{array}{l}\text { St. Francis River at } \\
\text { Wappapello, Mo. }\end{array}$ & 7,460 & 10,300 & 12,500 & 15,500 & 17,900 & 20,600 & 23,500 & 27,700 \\
\hline $\begin{array}{l}\text { St. Francis River at Parkin, } \\
\text { Ark. }\end{array}$ & 10,200 & 13,600 & 15,900 & 18,700 & 20,900 & 23,000 & 25,200 & 28,200 \\
\hline $\begin{array}{l}\text { St. Francis River at Madison, } \\
\text { Ark. }\end{array}$ & 25.50 & 31.57 & 34.49 & 37.80 & 40.06 & 42.16 & 44.16 & 46.66 \\
\hline \multicolumn{9}{|c|}{ Mississippi River } \\
\hline $\begin{array}{l}\text { Mississippi River at Memphis, } \\
\text { Tenn. }\end{array}$ & $1,193,000$ & $1,441,000$ & $1,589,000$ & $1,760,000$ & $1,880,000$ & $1,994,000$ & $2,103,000$ & $2,243,000$ \\
\hline $\begin{array}{l}\text { Mississippi River at Helena, } \\
\text { Ark. }\end{array}$ & $1,202,000$ & $1,446,000$ & $1,595,000$ & $1,774,000$ & $1,901,000$ & $2,025,000$ & $2,145,000$ & $2,302,000$ \\
\hline
\end{tabular}




\section{Joint Probability Analysis}

Eleven streamgages were paired to the Mississippi River at Helena, Ark. (07047970), streamgage. Seven of the 11 streamgages are located on the White River $(07074500$, 07074850, 07076750, 07076900, 07077000, 07077800, and 07077820), 3 on the Cache River (07077500, 07077555, and 07077600 ), and 1 on the Black River (07074420). For the joint probability analysis, streamflow data were used from the stations on the Mississippi River at Helena, Ark. (07047970), and White River at Newport, Ark. (07074500), but stage data were used from all the other stations. Not all daily value data consist of means. The annual peaks at six streamgages $(07047970,07074850,07076900,07077600$, 07077800, and 07077820) are based upon an annual maximum of single readings per day. For example, the stage is recorded once a day at 9 a.m. at the White River at Clarendon, Ark. (07077800), and White River at St. Charles, Ark. (07077820), streamgages. The once-a-day readings were substituted as the daily means. This is probably reasonable because floods on these streams rise and fall slowly, and the difference between the once-a-day reading and daily mean are small. Thus, steps 3 and 4 in the joint probability analysis methodology can be skipped, and the threshold exceedances in step 5 are set to the flood-frequency values calculated in step 2 .

Thresholds for the streamgages used in the joint probability analysis were calculated (step 5) and are shown in table 6 . The equations relating daily mean and peak values for streamflow or stage and their associated Pearson's correlation coefficients (r) are shown in table 6 . The correlations are all close to one indicating a strong positive linear association between daily mean and peak values.

The joint probabilities of flooding at the 50-, 10-, 4-, $2-$, and 1-percent flood threshold levels were computed at the 11 paired streamgages. Floods at paired streamgages were considered concurrent if they occur on the same day no matter the actual time that the peak occurred during the day. If thresholds were equaled or exceeded at both streams in the pair on consecutive days, each day was counted as a separate event.

Scatterplots of concurrent daily mean streamflows or stages (step 6) were developed for the 11 paired streamgages, but only 2 of the 11 are presented in this report (figs. 5 and 6) to help illustrate the results of the joint probability analysis. The results for all 11 are included in table 7. Figure 5 shows the concurrent daily mean streamflows for streamgages Mississippi River at Helena, Ark. (07047970), and White
River at Newport, Ark. (07074500). Points that were less than the 50-percent threshold for both streamgages were not shown. The number of points where the 50-percent threshold was exceeded for at least one of the streamgages was 803 (trials), which can be verified by adding all the red numbers (representing the count of points in each grid cell) on figure 5 . The number of points where the 50-percent threshold was exceeded at both streamgages was 145 (events), which can be verified by adding the red numbers that correspond only to grids cells in common for both streamgages that represent thresholds equal to or greater than 50 percent. Thus, the estimated joint probability for the 50-percent threshold exceedance was 0.181 (145/803). Similarly, the number of trials, events, and joint probability was determined for the other threshold levels (table 7). For these paired streamgages, the joint probabilities decreased as the threshold exceedance probabilities decreased. The 2-percent and 1-percent threshold exceedances were 0.000 . Note that streamflows at the White River at Newport, Ark. (07074500), have not equaled or exceeded the 2-percent exceedance threshold since 1967 (a record length of 45 years). Thus, a "not determined" (nd) was given in place of a zero value in table 7 because in this instance, it does not mean there is not a chance of the two streams having coincident floods at these exceedances. Similarly, this occurred at seven other streamgage pairs (table 7) that had zero events, and thus, the joint probabilities were replaced with "nd."

The concurrent daily mean streamflow for the Mississippi River at Helena, Ark. (07047970), and daily mean stage for the Cache River at Brasfield, Ark. (07077600), were graphed in a scatterplot (fig. 6). Again, points that were less than the 50-percent threshold for both streamgages were not shown on the scatterplot. The number of trials for the 50 -percent threshold exceedance was 1,291 (table 7), which is the total of all points on graph (red numbers provide total count of points within each grid cell). The number of events for the 50-percent threshold exceedance was 287 , which is the total of all points that correspond only to the grid cell in common for both streamgages that represent thresholds equal to or greater than 50 percent. Thus, the joint probability for the 50-percent threshold exceedance was $0.222(287 / 1,291)$. Similarly, the number of trials, events, and joint probability was determined for the other threshold levels (table 7). For the 1-percent threshold exceedance, a nd was given in place of a zero value because the Cache River at Brasfield, Ark. (07077600), never exceeded the 1-percent threshold exceedance in the period of record (61 years). 
Table 6. Equation and flood thresholds for streamgages used for joint probability analysis.

[DV, daily mean streamflow or daily mean stage; PK, peak streamflow or peak stage; NA, not applicable because annual exceedance probability flows are not based on daily mean streamflow; A water year is the 12-month period October 1 through September 30 designated by the calendar year in which it ends]

\begin{tabular}{|c|c|c|c|c|c|c|c|c|c|c|}
\hline \multirow{2}{*}{$\begin{array}{c}\text { Station } \\
\text { number } \\
\text { (figs. } 1 \\
\text { and 3) }\end{array}$} & \multirow{2}{*}{ Station name } & \multirow{2}{*}{$\begin{array}{l}\text { Data type } \\
\text { used for } \\
\text { calculating } \\
\text { thresholds }\end{array}$} & \multirow{2}{*}{ Equation } & \multirow{2}{*}{$\begin{array}{l}\text { Correla- } \\
\text { tion } \\
\text { coefficient } \\
\text { (r) }\end{array}$} & \multicolumn{5}{|c|}{$\begin{array}{l}\text { Flood threshold for indicated annual exceedance probability } \\
\qquad \text { (percent) })^{1}\end{array}$} & \multirow{2}{*}{$\begin{array}{l}\text { Period of record } \\
\text { for joint prob- } \\
\text { ability analysis } \\
\text { (water year) }\end{array}$} \\
\hline & & & & & 50 & 10 & 4 & 2 & 1 & \\
\hline 07047970 & $\begin{array}{l}\text { Mississippi River at } \\
\text { Helena, Ark. }\end{array}$ & Streamflow & NA & NA & $1,202,000$ & $1,595,000$ & $1,774,000$ & $1,901,000$ & $2,025,000$ & $1927-2011$ \\
\hline 07074420 & $\begin{array}{l}\text { Black River at Elgin } \\
\text { Ferry, Ark. }\end{array}$ & Stage & $\mathrm{DV}=0.986 \mathrm{PK}+0.235$ & 0.999 & 23.27 & 28.20 & 30.95 & 33.09 & 35.31 & $1991-2011$ \\
\hline 07074500 & $\begin{array}{l}\text { White River at Newport, } \\
\text { Ark. }\end{array}$ & Streamflow & $\mathrm{DV}=0.928 \mathrm{PK}+2590$ & 0.997 & 69,300 & 148,000 & 204,900 & 256,400 & 316,700 & $1967-2011$ \\
\hline 07074850 & $\begin{array}{l}\text { White River near Augusta, } \\
\text { Ark. }\end{array}$ & Stage & NA & NA & 32.87 & 37.03 & 38.86 & 40.15 & 41.39 & $1967,1984-2011$ \\
\hline 07076750 & $\begin{array}{l}\text { White River near } \\
\text { Georgetown, Ark. }\end{array}$ & Stage & $\mathrm{DV}=1.003 \mathrm{PK}-0.223$ & 0.988 & 22.35 & 27.99 & 30.59 & 32.46 & 34.27 & 1983-2011 \\
\hline 07076900 & $\begin{array}{l}\text { White River at Des Arc, } \\
\text { Ark. }\end{array}$ & Stage & NA & NA & 25.68 & 33.05 & 36.02 & 38.02 & 39.87 & $\begin{array}{l}1981, \\
1984-1991, \\
1995-2001 \\
2004-11\end{array}$ \\
\hline 07077000 & $\begin{array}{l}\text { White River at De Valls } \\
\text { Bluff, Ark. }\end{array}$ & Stage & $\mathrm{DV}=1.002 \mathrm{PK}-0.087$ & 0.999 & 24.38 & 29.38 & 31.46 & 32.88 & 34.22 & $\begin{array}{l}\text { 1967, 1969-72, } \\
1974-77, \\
1979-82, \\
1984-87, \\
1989-93, \\
1995-97 \\
1999-2011\end{array}$ \\
\hline 07077500 & $\begin{array}{l}\text { Cache River near } \\
\text { Patterson, Ark. }\end{array}$ & Stage & $\mathrm{DV}=0.994 \mathrm{PK}+0.04$ & 0.999 & 10.48 & 12.22 & 13.09 & 13.73 & 14.38 & $1987-2011$ \\
\hline 07077555 & $\begin{array}{l}\text { Cache River near Cotton } \\
\text { Plant, Ark. }\end{array}$ & Stage & $\mathrm{DV}=0.997 \mathrm{PK}+0.015$ & 0.999 & 19.28 & 20.18 & 20.43 & 20.57 & 20.68 & $1987-2011$ \\
\hline 07077600 & $\begin{array}{l}\text { Cache River at Brasfield, } \\
\text { Ark. }\end{array}$ & Stage & NA & NA & 26.09 & 30.60 & 32.85 & 34.52 & 36.18 & 1951-2011 \\
\hline 07077800 & $\begin{array}{l}\text { White River at Clarendon, } \\
\text { Ark. }\end{array}$ & Stage & NA & NA & 28.36 & 33.01 & 35.00 & 36.39 & 37.71 & $\begin{array}{c}1967-74,1976- \\
77,1979-84 \\
1996-2011\end{array}$ \\
\hline
\end{tabular}

${ }^{1}$ Flood thresholds represent daily mean streamflow magnitudes expected to occur on days when an instantaneous peak streamflow with a magnitude corresponding to the indicated annual exceedance probability occurs. 
Table 7. Results of streamgage joint probabilities at selected streamgages paired with the Mississippi River at Helena, Arkansas, streamgage (07047970).

[nd, not determined]

\begin{tabular}{|c|c|c|c|c|c|c|c|c|c|c|}
\hline & \multicolumn{10}{|c|}{$\begin{array}{l}\text { Flood threshold for indicated annual exceedance probability } \\
\text { (percent) })^{1}\end{array}$} \\
\hline & 50 & 10 & 4 & 2 & 1 & 50 & 10 & 4 & 2 & 1 \\
\hline Station name (station number) & \multicolumn{5}{|c|}{ Black River at Elgin Ferry, Ark. (07074420) } & \multicolumn{5}{|c|}{ Cache River near Patterson, Ark. (07077500) } \\
\hline Events $^{2}$ & 84 & 9 & 3 & 0 & 0 & 125 & 5 & 0 & 0 & 0 \\
\hline Trials $^{3}$ & 308 & 37 & 24 & 20 & 7 & 644 & 35 & 16 & 12 & 7 \\
\hline Joint probability ${ }^{4}$ & 0.273 & 0.243 & 0.125 & $\mathrm{nd}^{5}$ & $\mathrm{nd}^{5}$ & 0.194 & 0.143 & $\mathrm{nd}^{5}$ & $\mathrm{nd}^{5}$ & $\mathrm{nd}^{5}$ \\
\hline Station name (station number) & \multicolumn{5}{|c|}{ White River at Newport, Ark. (07074500) } & \multicolumn{5}{|c|}{ Cache River near Cotton Plant, Ark. (07077555) } \\
\hline Events $^{2}$ & 145 & 6 & 2 & 0 & 0 & 61 & 0 & 0 & 0 & 0 \\
\hline Trials $^{3}$ & 803 & 69 & 22 & 12 & 7 & 363 & 1 & 0 & 0 & 0 \\
\hline Joint probability ${ }^{4}$ & 0.181 & 0.087 & 0.091 & $\mathrm{nd}^{5}$ & $\mathrm{nd}^{5}$ & 0.168 & ${ }^{5} 0.000$ & $\mathrm{nd}^{5}$ & $\mathrm{nd}^{5}$ & $\mathrm{nd}^{5}$ \\
\hline Station name (station number) & \multicolumn{5}{|c|}{ White River near Augusta, Ark. (07074850) } & \multicolumn{5}{|c|}{ Cache River at Brasfield, Ark. (07077600) } \\
\hline Events $^{2}$ & 65 & 6 & 3 & 2 & 0 & 287 & 12 & 6 & 1 & 0 \\
\hline Trials $^{3}$ & 468 & 24 & 14 & 9 & 8 & 1,291 & 61 & 13 & 9 & 4 \\
\hline Joint probability ${ }^{4}$ & 0.139 & 0.250 & 0.214 & 0.222 & $\mathrm{nd}^{5}$ & 0.222 & 0.197 & 0.462 & 0.111 & $\mathrm{nd}^{5}$ \\
\hline Station name (station number) & \multicolumn{5}{|c|}{ White River near Georgetown, Ark. (07076750) } & \multicolumn{5}{|c|}{ White River at Clarendon, Ark. (07077800) } \\
\hline Events $^{2}$ & 98 & 2 & 0 & 0 & 0 & 249 & 16 & 12 & 7 & 0 \\
\hline Trials $^{3}$ & 618 & 30 & 9 & 6 & 3 & 840 & 60 & 16 & 12 & 7 \\
\hline Joint probability ${ }^{4}$ & 0.159 & 0.067 & $\mathrm{nd}^{5}$ & $\mathrm{nd}^{5}$ & $\mathrm{nd}^{5}$ & 0.296 & 0.267 & 0.750 & 0.583 & $\mathrm{nd}^{5}$ \\
\hline Station name (station number) & \multicolumn{5}{|c|}{ White River at Des Arc, Ark. (07076900) } & \multicolumn{5}{|c|}{ White River at St. Charles, Ark. (07077820) } \\
\hline Events $^{2}$ & 165 & 14 & 9 & 5 & 1 & 363 & 28 & 13 & 8 & 3 \\
\hline Trials $^{3}$ & 695 & 35 & 17 & 14 & 10 & 836 & 112 & 37 & 16 & 10 \\
\hline Joint probability ${ }^{4}$ & 0.237 & 0.400 & 0.529 & 0.357 & 0.100 & 0.434 & 0.250 & 0.351 & 0.500 & 0.300 \\
\hline Station name (station number) & \multicolumn{5}{|c|}{ White River at De Valls Bluff, Ark. (07077000) } & & & & & \\
\hline Events $^{2}$ & 198 & 14 & 10 & 6 & 2 & & & & & \\
\hline Trials $^{3}$ & 818 & 65 & 16 & 13 & 9 & & & & & \\
\hline Joint probability ${ }^{4}$ & 0.242 & 0.215 & 0.625 & 0.462 & 0.222 & & & & & \\
\hline
\end{tabular}

${ }^{1}$ Flood thresholds represent the equivalent of peak streamflow flood frequencies for daily mean streamflow.

${ }^{2} \mathrm{An}$ event occurrs when the threshold is equaled or exceeded at both streamgages in the pair.

${ }^{3} \mathrm{~A}$ trial occurs when the threshold is equaled or exceeded in at least one streamgage in the pair.

${ }^{4} \mathrm{Joint}$ probability is events divided by trials.

${ }^{5}$ The streamgage on one of the rivers (White, Black, or Cache) does not have any observations that exceed the flood threshold. 
Three streamgage pairs had a joint probability equal to or greater than 0.100 for the 1-percent threshold exceedance (table 7). The paired streamgages of Mississippi River at Helena, Ark. (07047970), and White River at De Valls Bluff, Ark. (07077000), had a joint probability of 0.222 for the 1-percent threshold exceedance; the two events and nine trials occurred on two consecutive days, May 8 and 9, 2011. May 2011 was the highest flood of record for many streams in Arkansas. The paired streamgages Mississippi River at Helena, Ark. (07047970), and White River at Des Arc, Ark. (07076900), had a joint probability of 0.100 for the 1 -percent threshold exceedance; the one event and 10 trials were also caused by the April-May 2011 flooding, which occurred in 10 consecutive days from May 5 through May 14. The paired streamgages Mississippi River at Helena, Ark. (07047970), and White River at St. Charles, Ark. (07077820), had a joint probability of 0.300 for the 1-percent threshold exceedance; the three events and 10 trials were also caused by the April-May 2011 flooding, which occurred in 10 consecutive days from May 8 through May 17. If the April-May 2011 flooding had not occurred, then the joint probabilities would have been zero at these streamgages. Steps 9 and 10 in the joint probability methodology were not necessary for these streamgages. The instantaneous peak data and daily mean data were checked to see if a revision to the number of events and trials was needed, but no changes resulted because of the slow rise and fall of floods on these streams.

The joint probability values presented in table 7 are the results with streamgages paired with the Mississippi River at Helena, Ark., streamgage (07047970). Overall, these values indicate a low probability of concurrent flooding on the two rivers (paired sites) as more than one-half of the values were less than 0.2 percent. However, five joint probability values were equal to or greater than 0.5 percent, which was associated with streamgages located near the downstream end of the White River. Also, values for each threshold exceedance generally increased with streamgages located downstream and the increasing drainage area. Some of the zero values in the 2-percent and 1-percent threshold exceedances are questionable and, in general, probably should not be applied with a high degree of confidence because no flood events occurred at these exceedances.

\section{Flood-Inundation Maps}

Flood-peak inundation maps were created for two stream reaches on the White River and two on the Black River; the vicinity of the communities of Holly Grove, Ark., and Cotton Plant, Ark.; a reach of the White River that included the crossing of Interstate 40 north of De Valls Bluff, Ark.; and the Tailwaters of Beaver Dam near Eureka
Springs, Ark., Table Rock Dam near Branson Mo., and Bull Shoals Dam near Flippin, Ark. (fig. 3, table 3). Personnel from the USGS, USACE, and AHTD collected $122 \mathrm{HWMs}$ (appendix 1).

Flood-peak inundation maps were generated for each selected area showing the maximum areal extents and depths of the floodwaters (figs. 7-16). The water depths for each map are continuous and show how the flood-peak inundation area and slope varied along each stream reach and the affected community. The inundation maps also contain locations and elevations of HWMs used to develop the map. The maps were checked by USGS surveying and HWM personnel, spatially checked against the HWMs for mathematical or other inconsistency errors, and compared with field collected photographs to ensure the inundations maps were as accurate as the available data. The digital data used to create the inundation map for each area are available in a downloadable GIS compatible format (http://pubs.usgs.gov/sir/2013/5148/ Downloads).

Two stream reaches were mapped on the White River: (1) an approximately 40 river-mile reach extending from Batesville to Newport, Ark. (fig. 7), and (2) an approximately 110 river-mile reach extending from Newport to Des Arc, Ark. (fig. 8). The first stream reach (fig. 7) includes the White River downstream from several flood-control impoundments and the confluence of the Black River near Newport, Ark. The flood plain was less than 2 mi wide along the upstream reach of the White River and expanded to nearly $9 \mathrm{mi}$ wide at the downstream end of the reach. The reach from Newport to Des Arc, Ark. (fig. 8), becomes increasingly leveed, and this section includes the tributary of the Little Red River (fig. 3). For both stream reaches, the greatest water depths (maximum of $36 \mathrm{ft}$ ) were located at and downstream from the confluence with the White and Black Rivers.

The two stream reaches mapped on the Black River were from: (1) Corning to Pocahontas, Ark., approximately 60 river miles (fig. 9) and (2) Pocahontas, Ark. (fig. 10), to the confluence with the White River near Newport, Ark., approximately 100 river miles. The Black River overtopped its banks and spread out 1 to $4 \mathrm{mi}$ on either side of the channel from Corning to Pocahontas (fig. 9). Near Pocahontas, several levee breaches occurred that permitted the flood to extend beyond the levee structures. The maximum depth was $28 \mathrm{ft}$ near the levee breaches (both stream reaches mapped include the area surrounding Pocahontas). Additional levee breaches occurred along the second stream reach of the Black River, south of Pocahontas and west of Swifton, Ark. (fig. 10), and both occurrences permitted the land behind levees to become inundated. The greatest depths (maximum of $39 \mathrm{ft}$ ) were along the Black River upstream from the confluence with the White River. 


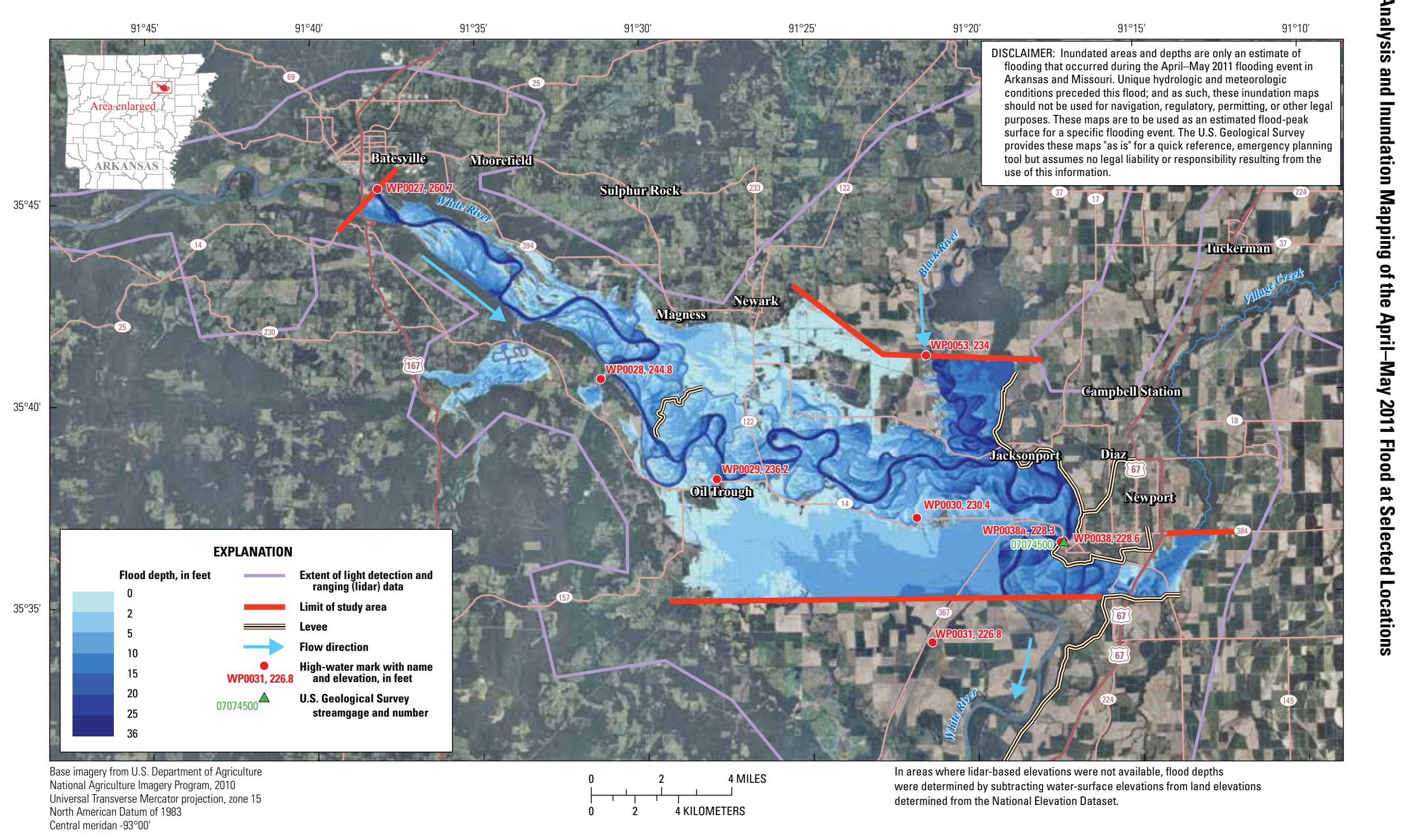

Figure 7. Flood-peak extent and water-depth inundation map for the White River from Batesville to Newport, Arkansas. 


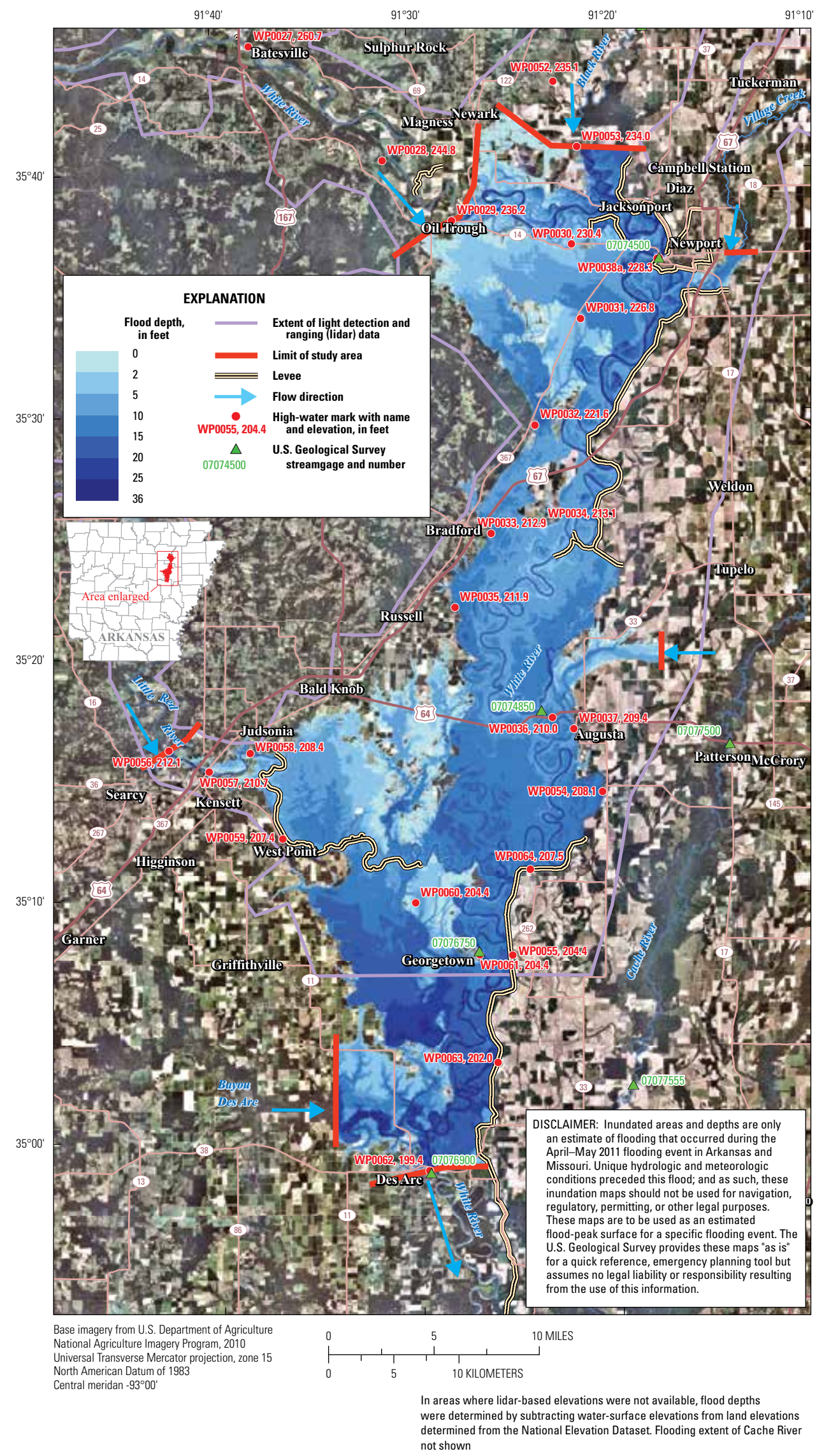

Figure 8. Flood-peak extent and water-depth inundation map for the White River from Newport to Des Arc, Arkansas. 


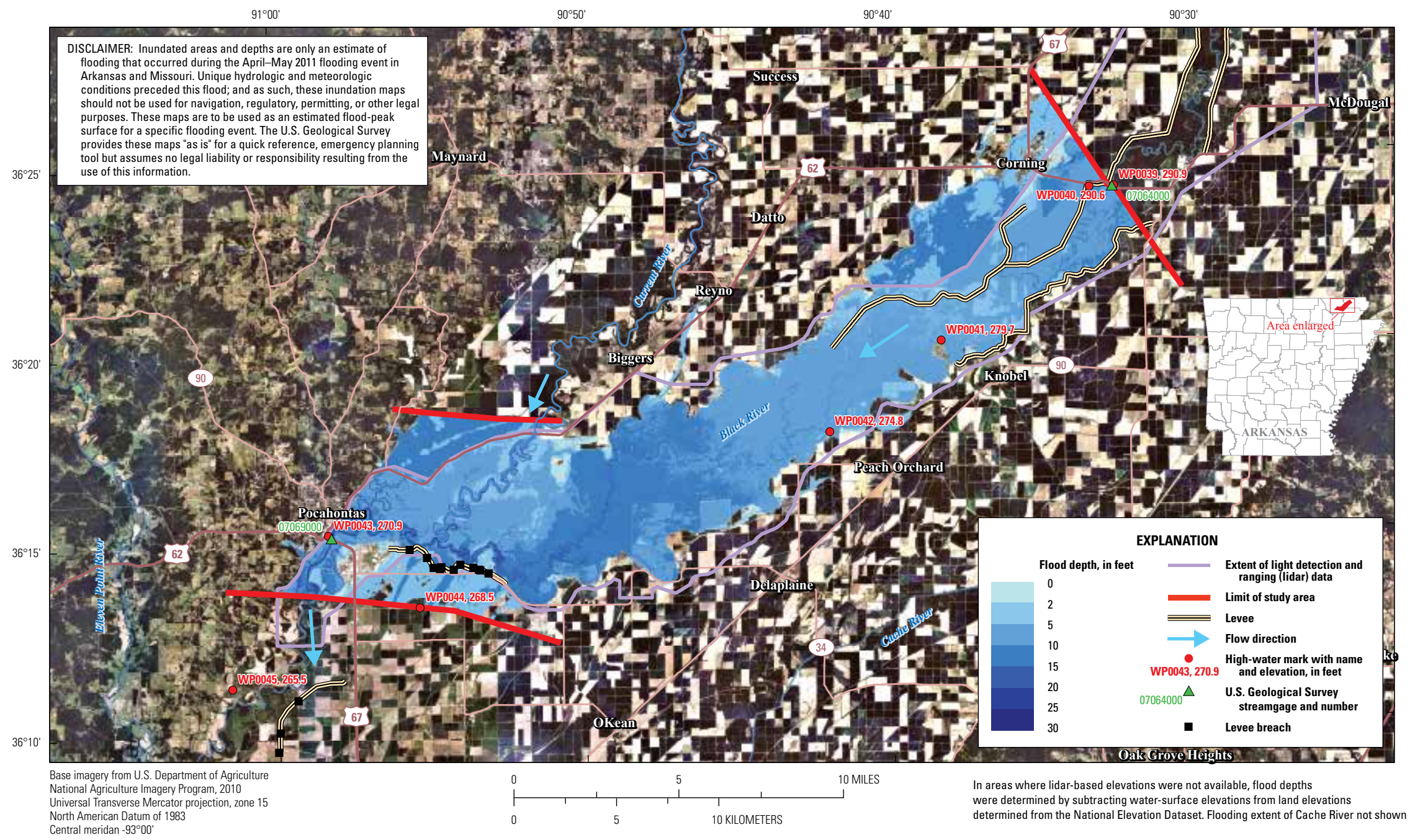

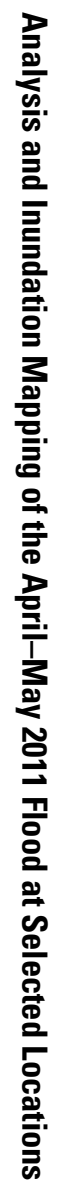

Figure 9. Flood-peak extent and water-depth inundation map for the Black River from Corning to Pocahontas, Arkansas. 


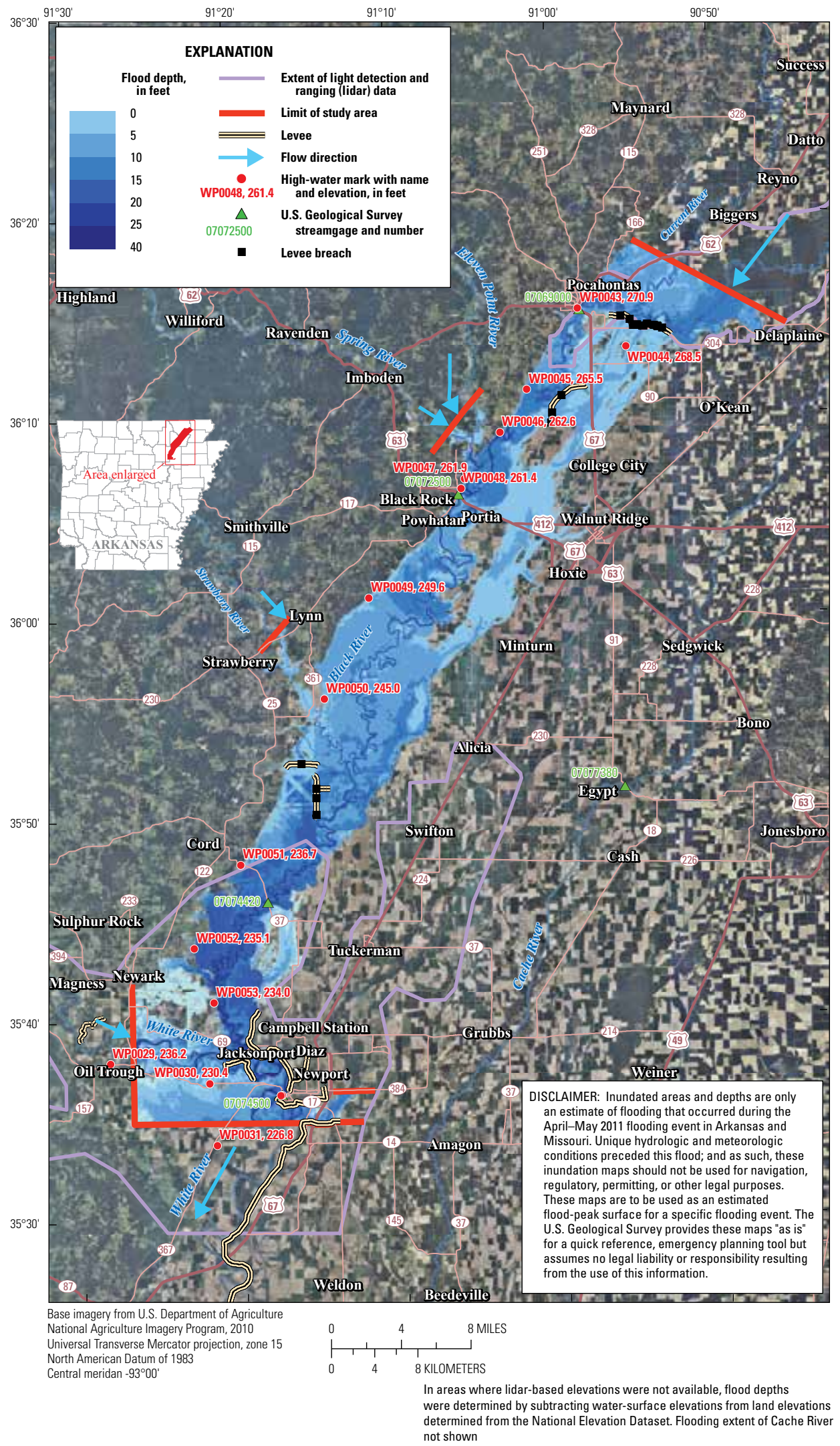

Figure 10. Flood-peak extent and water-depth inundation map for the Black River from Pocahontas to the confluence with the White River near Newport, Arkansas. 


\section{Analysis and Inundation Mapping of the April-May 2011 Flood at Selected Locations}

Two small communities where inundation maps were generated include: (1) Holly Grove, in southeastern Arkansas adjacent to the Maddox Bay (also known as Dial Creek; fig. 11), a tributary of the White River, approximately 1.5 river miles, and (2) Cotton Plant, Ark., adjacent to the Cache River, just upstream from its confluence with the White River (fig. 12), approximately 15 river miles. Adjacent to Holly Grove, the extent of flooding reached a total width slightly more than $0.5 \mathrm{mi}$, and the maximum depth along the channel was $4 \mathrm{ft}$. Adjacent to Cotton Plant, flooding stretched from the stream channel to the west over $6 \mathrm{mi}$, nearly reaching the levees designed to regulate flow on the White River. The maximum depth reached by the flooding was estimated to be $22 \mathrm{ft}$.

A reach of the White River that included the crossing of Interstate 40 north of De Valls Bluff, Ark. (fig. 3), was the most downstream inundation map produced for a location on the White River and included approximately 5 river miles (fig. 13). Interstate 40 was inundated on both sides of the bridge over the White River. The eastern extent of the flood was controlled by the levee approximately $1.5 \mathrm{mi}$ east of the stream channel. The maximum depth within the channel reached $69 \mathrm{ft}$, and the maximum depth over the surrounding land was approximately $22 \mathrm{ft}$. Stream channel bathymetry data improved the depth approximation with the channel.
The three White River lakes are artificial impoundments of the White River in northwestern Arkansas and southern Missouri managed by the USACE-LR and include the Tailwaters of (1) Beaver Dam near Eureka Springs, Ark., (2) Table Rock Dam near Branson, Mo., and (3) Bull Shoals Dam near Flippin, Ark. (fig. 3). The mountainous topography helped to confine the flood downstream from Beaver Dam Tailwater (fig. 14). About 7 river miles downstream from Beaver Dam, the maximum depth was approximately 36 $\mathrm{ft}$. The maximum recordable elevation of the Beaver Dam Tailwater streamgage (07049691) was exceeded and, therefore, the actual peak stage was higher than the recorded value at this location $(953.00 \mathrm{ft})$. Downstream $0.4 \mathrm{mi}$ from the Tailwater streamgage, the water-surface elevation was determined to be $953.4 \mathrm{ft}$ at HWM WP0020 (appendix 1). Downstream from Table Rock Dam Tailwater, approximately 22 total river miles (fig. 15), the greatest estimated depth was $28 \mathrm{ft}$, and the flood plain was generally less than 900 $\mathrm{ft}$ wide for the first 15 river miles. The flood plain widened to near 2,600 ft in the last 7 river miles. The flood plain below Bull Shoals Dam Tailwater (fig. 16) generally was no wider than 1,200 feet and was less than $700 \mathrm{ft}$ wide at the downstream boundary of the 30 river miles that were mapped. The maximum depth below Bull Shoals Dam Tailwater was approximately $21 \mathrm{ft}$ near the downstream boundary of the mapped reach. 


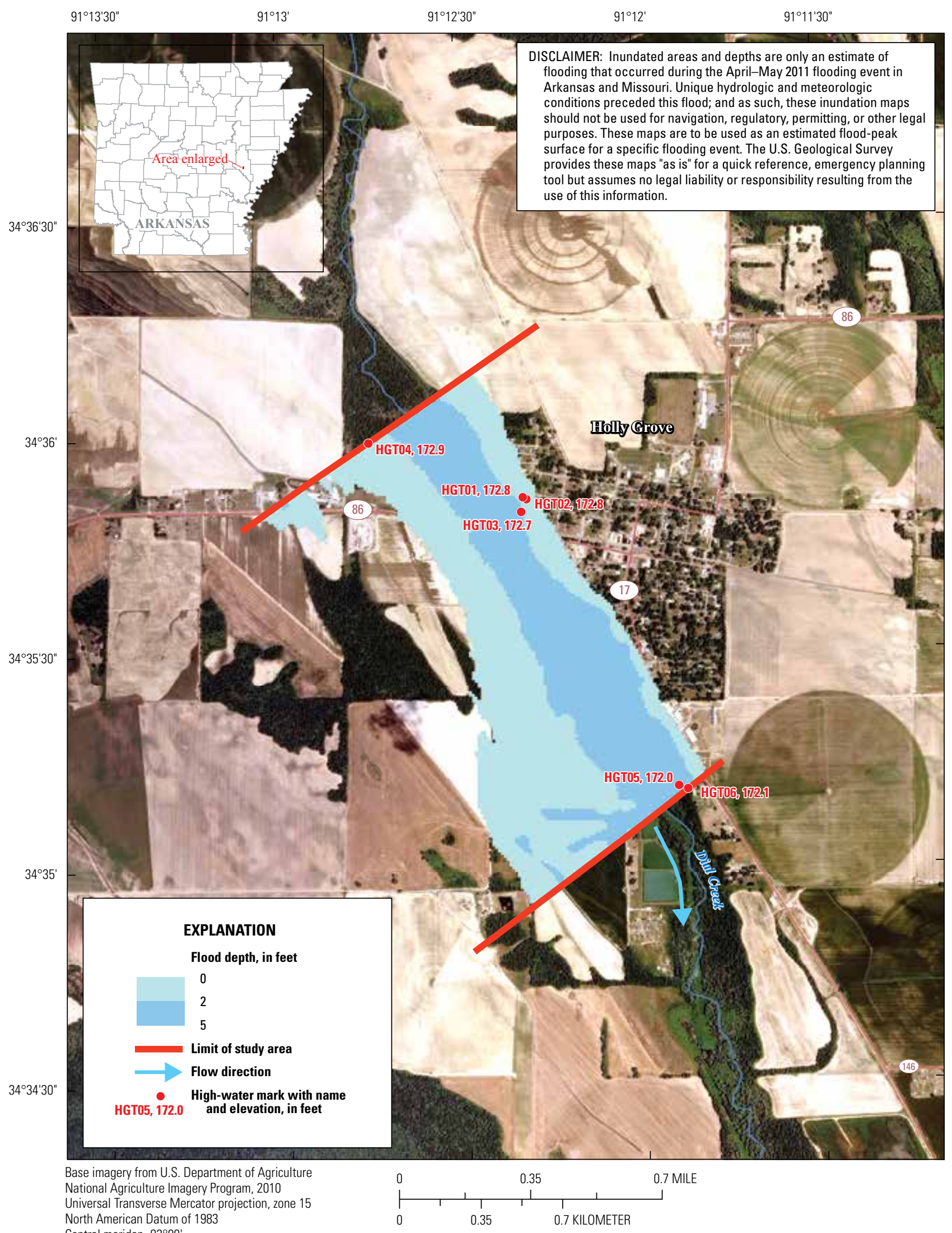

Figure 11. Flood-peak extent and water-depth inundation map for the town of Holly Grove, Arkansas, adjacent to a tributary of the White River, Maddox Bay (also known as Dial Creek). 


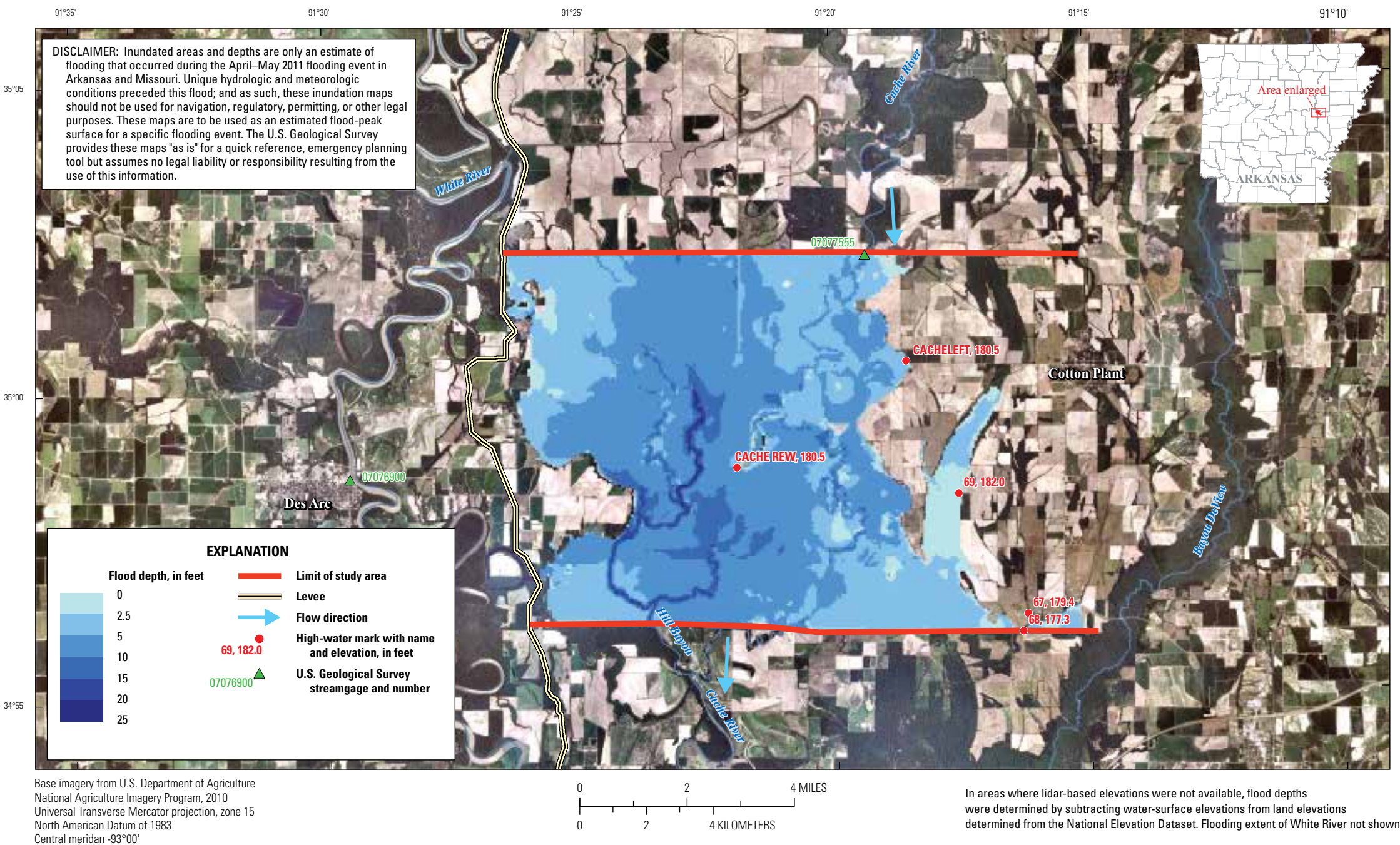

Figure 12. Flood-peak extent and water-depth inundation map for the town of Cotton Plant, Arkansas, adjacent to the Cache River. 


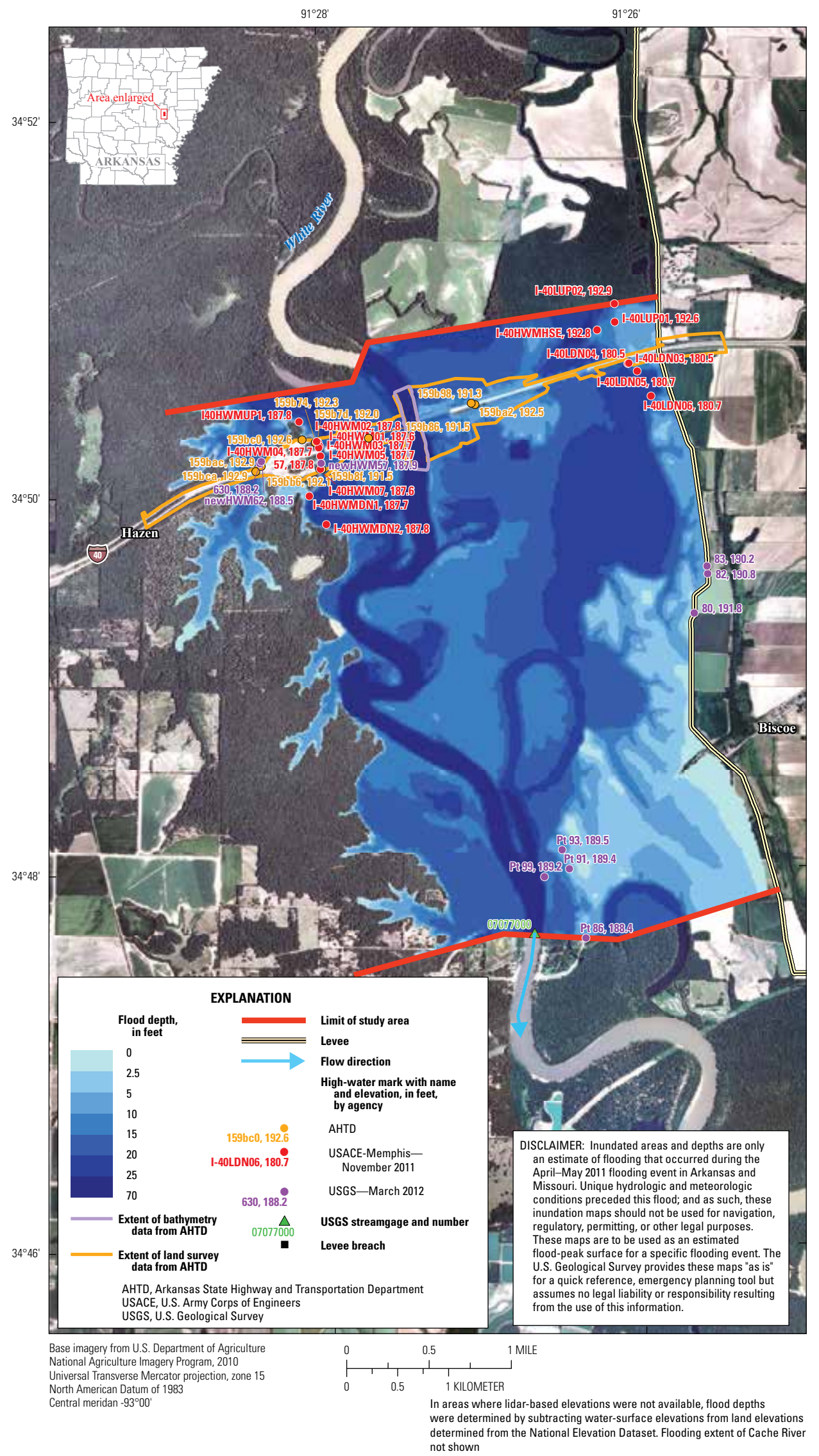

Figure 13. Flood-peak extent and water-depth inundation map for the Interstate-40 crossing with the White River, Arkansas. 


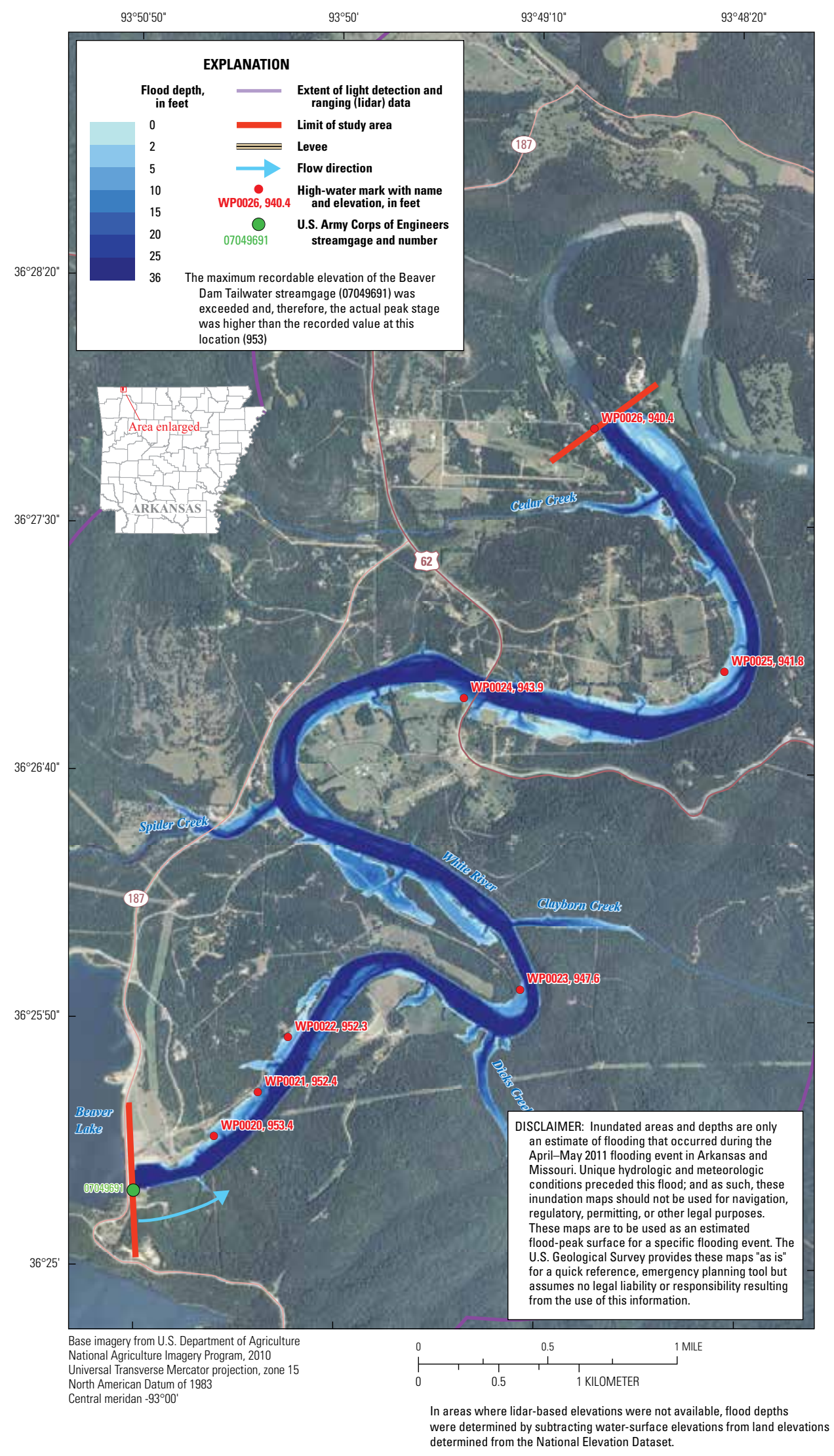

Figure 14. Flood-peak extent and water-depth inundation map for the White River at Beaver Dam Tailwater near Eureka Springs, Arkansas. 


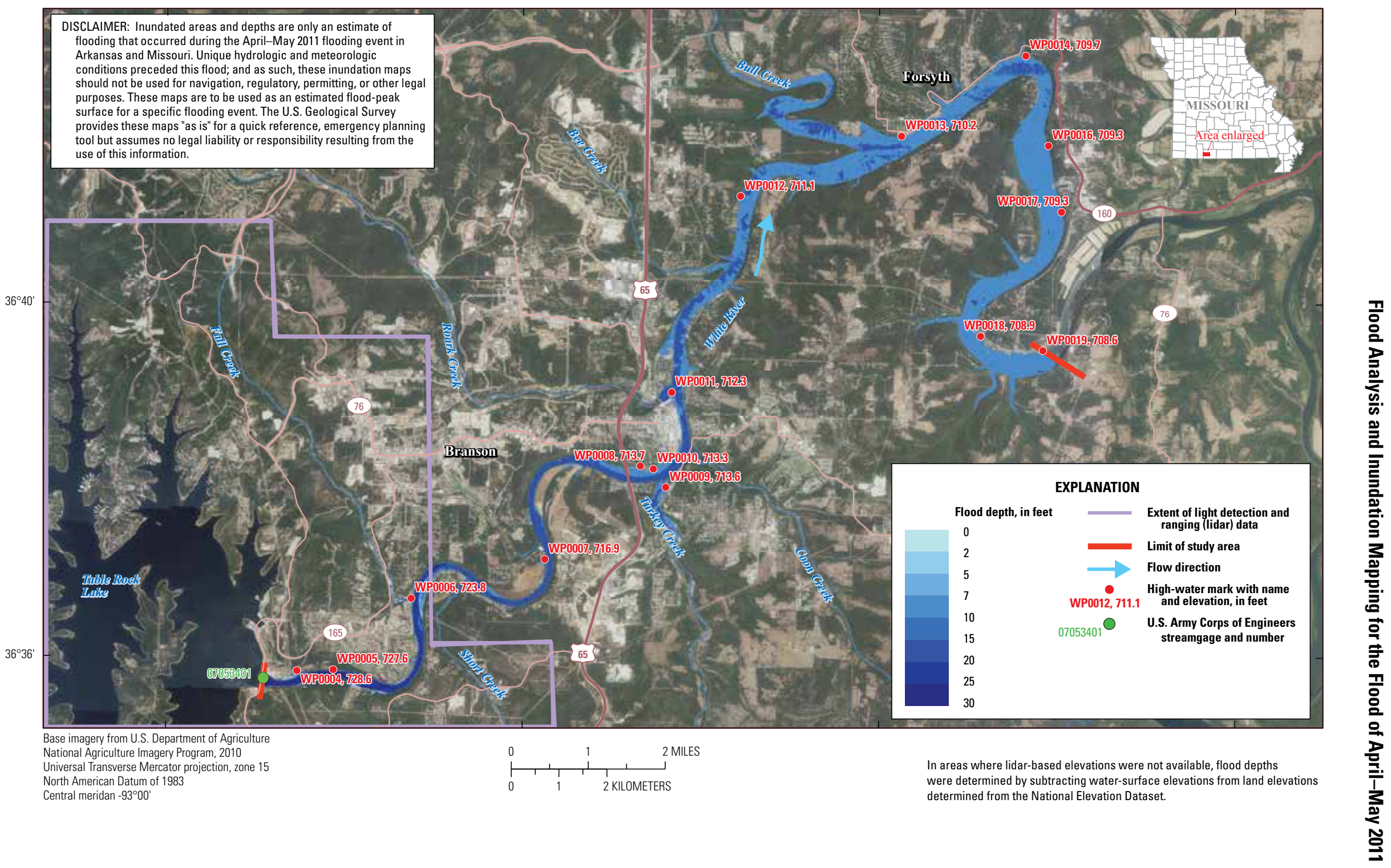

Figure 15. Flood-peak extent and water-depth inundation map for the White River at Table Rock Dam Tailwater near Branson, Missouri. 


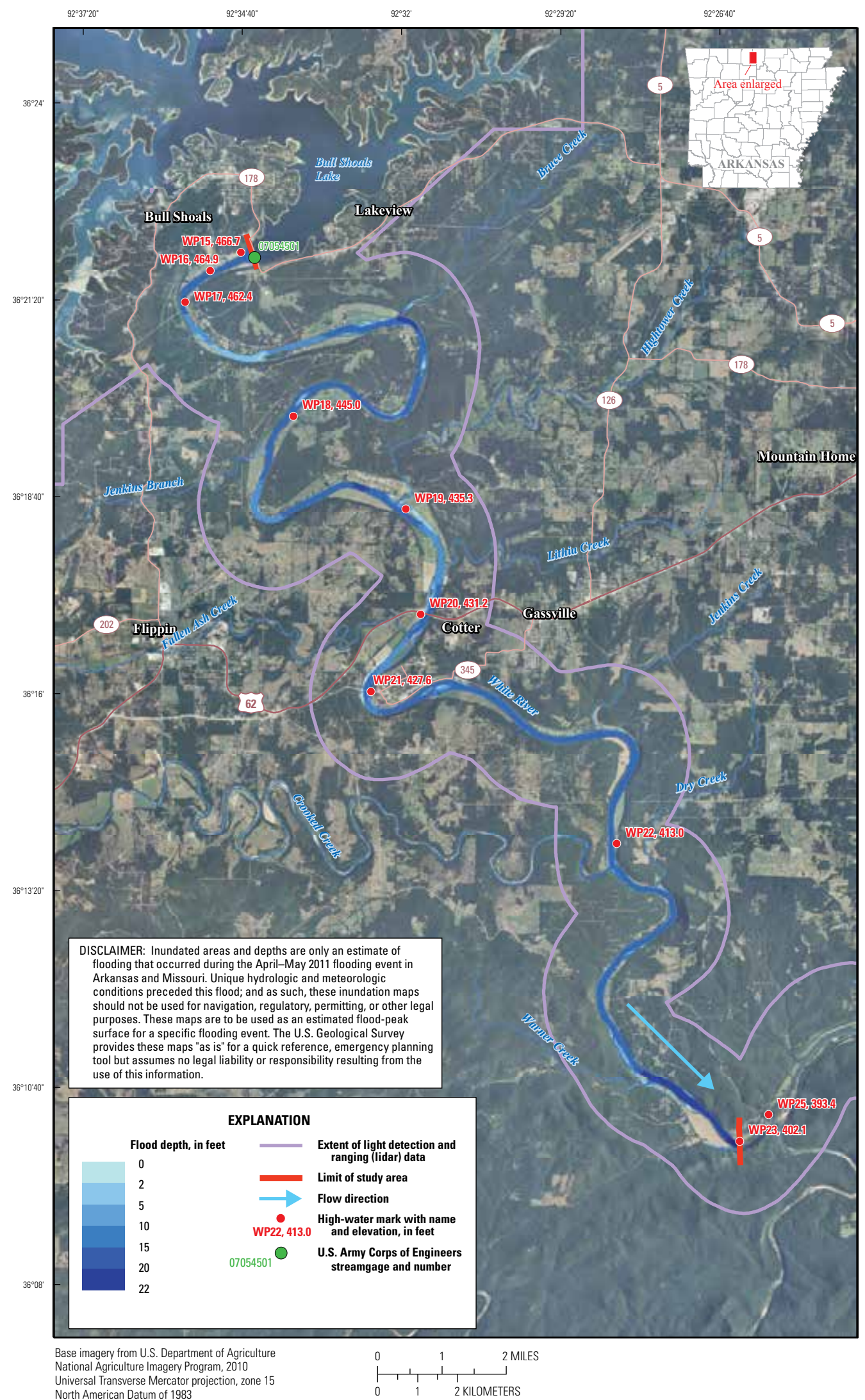
Universal Transverse Mercator projection, zone 15 Central meridan $-93^{\circ} 00^{\prime}$

In areas where lidar-based elevations were not available, flood depths were determined by subtracting water-surface elevations from land elevations determined from the National Elevation Dataset.

Figure 16. Flood-peak extent and water-depth inundation map for the White River at Bull Shoals Dam Tailwater near Flippin, Arkansas. 


\section{Summary}

Precipitation that fell from April 19 through May 3, 2011, resulted in widespread flooding across northern and eastern Arkansas and southern Missouri. The first storm produced a total of approximately 16 inches of precipitation over an 8-day period, and the following storms produced as much as 12 inches of precipitation over a 2-day period. Moderate to major flooding occurred quickly along many streams within Arkansas and Missouri (including the Black, Cache, Illinois, St. Francis, and White Rivers) at levels that had not been seen since the historic 1927 floods. The 2011 flood claimed an estimated 21 lives in Arkansas and Missouri, and damage caused by the flooding resulted in a Federal Disaster Declaration for 59 Arkansas counties that received Federal or State assistance. Extensive flood information was collected during and post-flood to appropriately document and analyze the flooding event.

To further the goal of documenting and understanding floods, the U.S. Geological Survey (USGS), in cooperation with the Federal Emergency Management Agency, the U.S. Army Corps of Engineers-Little Rock and Memphis Districts, and the Arkansas Natural Resources Commission, conducted a study to summarize meteorological and hydrological conditions leading up to the flood; computed flood-peak magnitudes for 39 streamgages; estimated annual exceedance probabilities for 37 of those streamgages; determined the joint probabilities for 11 streamgages paired to the Mississippi River at Helena, Ark., which refers to the probability that locations on two paired streams simultaneously experience floods of a magnitude greater than or equal to a given annual exceedance probability; collected high-water marks; constructed flood-peak inundation maps showing maximum flood extent and water depths; and summarized flood damages and effects.

For the period of record used in this report, peak-ofrecord stage occurred at 24 of the 39 streamgages, and peakof-record streamflow occurred at 13 of the 30 streamgages where streamflow was determined. Annual exceedance probabilities of flooding at the 50-, 20-, 10-, 4-, 2-, 1-, 0.5-, and 0.2-percent flood threshold levels were computed for the 37 streamgages. Annual exceedance probabilities were estimated to be less than 0.2 percent (recurrence interval greater than 500 years) at one streamgage, St. Francis River at Wappapello, Mo. Annual exceedance probabilities were less than 0.5 percent (recurrence interval greater than 200 years) at three streamgages, both Mississippi River streamgages at Memphis, Tenn., and Helena, Ark., and the White River near Augusta, Ark. The joint probability values for streamgages paired with the Mississippi River at Helena, Ark., streamgage indicate a low probability of concurrent flooding on the two rivers (paired sites) as more than one-half of the values were less than 0.2 percent. However, five joint probability values were equal to or greater than 0.5 percent, which was associated with streamgages located near the downstream end of the White River.
Inundation maps were produced by use of a geographic information system on the basis of high-water-mark data from 122 locations and the highest resolution digital elevation model data available. The inundation maps show the floodpeak extent and water depth of flooding for two stream reaches on the White River and two on the Black River; the vicinities of the communities of Holly Grove, and Cotton Plant, Ark.; a reach of the White River that included the crossing of Interstate 40 north of De Valls Bluff, Ark.; and the Tailwaters of Beaver Dam near Eureka Springs, Ark., Table Rock Dam near Branson, Mo., and Bull Shoals Dam near Flippin, Ark. The data and inundation maps can be used for flood response, recovery, and planning efforts by Federal, State, and local agencies.

\section{References}

Arkansas State Highway and Transportation Department, 2011, Floodwaters cover highways in Arkansas: CenterLine Newsletter, accessed November 5, 2012, at http://www. arkansashighways.com/newsletters/2011/CenterLine $\% 20$ Color\%20May\%202011.pdf.

Bales, J.D., and Wagner, C.R., 2009, Sources of uncertainty in flood inundation maps: Journal of Flood Risk Management, v. 2, p. 139-147.

Benson, M.A., and Dalrymple, Tate, 1967, General field and office procedures for indirect measurements: U.S. Geological Survey Techniques of Water-Resources Investigations, book 3 , chap. A1, $30 \mathrm{p}$.

Christensen, C.R., Gilstrap, C.R., and Sullavan, N.J., 1967, Drainage areas of streams in Arkansas-St. Francis River Basin: U.S. Geological Survey Open-File Report, 32 p.

Cohn, T.A., 2011, PeakfqSA/EMA Version 0.972 (software), accessed July 1, 2011, at http://www.timcohn.com/TAC_ Software/PeakfqSA/.

Cohn, T., Lane, W.L., and Baier, W.G., 1997, An algorithm for computing moments-based flood estimates when historical flood information is available: Water Resources Research, v. 33, no. 9, p. 2089-2096.

Cohn, T., Lane, W.L., and Stedinger, J.R., 2001, Confidence intervals for EMA flood quantile estimates: Water Resources Research, v. 37, no. 6, p. 1695-1706.

Ellison, C.A., Sanocki, C.A., Lorenz, D.L., Mitton, G.B., and Kruse, G.A., 2011, Floods of September 2010 in southern Minnesota: U.S. Geological Survey Scientific Investigations Report 2011-5045, 37 p.

Esri, 2010, ArcGIS Desktop 10.0: Redlands, Calif., Esri Headquarters. 
Federal Emergency Management Agency, 2011, Disaster Federal Registry Notice Amendment No. 9: Washington, D.C., ITS Mapping and Analysis Center, accessed July 1, 2012, at http://gis.fema.gov/maps/dec_1975.pdf.

Federal Highway Administration, 2012, U.S Transportation Secretary LaHood announces close to $\$ 1.6$ billion in funding for repairs to damaged roads and bridges: Office of Public Affairs Press Release FHWA 02-12, accessed November 5, 2012, at http://www.fhwa.dot.gov/pressroom/ fhwa1202.htm.

Follansbee, R., and Jones, E.E., 1922, The Arkansas River flood of June 3-5, 1921: U.S. Geological Survey WaterSupply Paper 487, $44 \mathrm{p}$.

Galloway, J.M., 2008, Determination of organic and inorganic percentages and mass of suspended material at four sites in the Illinois River in northwestern Arkansas and northeastern Oklahoma, 2005-07: U.S. Geological Survey Scientific Investigations Report 2008-5136, $31 \mathrm{p}$.

Gesch, D.B., 2007, The National Elevation Dataset, in Maune, D., ed., Digital elevation model technologies and applications-The DEM users manual, 2d ed.: Bethesda, Maryland, American Society for Photogrammetry and Remote Sensing, p. 99-118.

Gesch, D., Oimoen, M., Greenlee, S., Nelson, C., Steuck, M., and Tyler, D., 2002, The National Elevation Dataset: Photogrammetric Engineering and Remote Sensing, v. 68, no. 1 , p. 5-11.

Griffis, V.W., Stedinger, J.R., and Cohn, T.A., 2004, LP3 quantile estimators with regional skew information and low outlier adjustments: Water Resources Research, v. 40, W07503, doi:1029/2003WR002697.

Grover, N.C., 1938, Floods of the Ohio and Mississippi Rivers, January-February 1937: U.S. Geological Survey Water-Supply Paper 838, 746 p.

Heidemann, Hans Karl, 2012, Lidar base specification version 1.0: U.S. Geological Survey Techniques and Methods, book 11, chap. B4, 63 p.

Holmes, R.H., and Dinicola, K.E., 2010, 100-year flood-It's all about chance: Haven't we already had one this century?: U.S. Geological Survey General Information Product 106, $4 \mathrm{p}$.

Holmes, R.R., Jr., Koenig, T.A., and Karstensen, K.A., 2010, Flooding in the United States Midwest, 2008: U.S. Geological Survey Professional Paper 1775, 64 p.

Interagency Advisory Committee on Water Data, 1982, Guidelines for determining flood-flow frequency: U.S. Geological Survey Bulletin \#17B of the Hydrology Subcommittee, Reston, Virginia, Office of Water Data Coordination, $183 \mathrm{p}$.
Judd, L.J., Asquith, W.H., and Slade, R.M., Jr., 1996, Techniques to estimate generalized skew coefficients of annual peak streamflow for natural basins in Texas: U.S. Geological Survey Scientific Investigations Report 96-4117, $28 \mathrm{p}$.

Koltun, G.F., and Sherwood, J.M., 1998, Factors related to the joint probability of flooding on paired streams: U.S. Geological Survey Water-Resources Investigations Report 98-4238, $32 \mathrm{p}$.

Kennedy, E.J., 1984, Discharge ratings at gaging stations: U.S. Geological Survey Techniques of Water-Resources Investigations, book 3, chap. A10, 59 p. (Also available at http://pubs.usgs.gov/twri/twri3-a10/.)

Linsley, R.K., Kohler, M.A., and Paulhus, J.L.H., 1975, Hydrology for engineers: New York, McGraw-Hill, 481 p.

Lumia, Richard, Burke, P.M., and Johnston, W.H., 1986, Flooding of December 29, 1984, through January 2, 1985, in northern New York State, with flood profiles of the Black and Salmon Rivers: U.S. Geological Survey WaterResources Investigations Report 86-4191, 53 p.

McCain, J.F., Hoxit, L.R., Maddox, R.A., Chappell, C.F., and Caracena, Fernando, 1979, Storm and flood of July 31-August 1, 1976, in the Big Thompson River and Cache la Poudre River Basins, Larimer and Weld Counties, Colorado: U.S. Geological Survey Professional Paper 1115B, $85 \mathrm{p}$.

Merwade, V.F., Arabi, O.M., and Edleman, S., 2008, Uncertainty in flood inundation mapping - Current issues and future directions: Journal of Hydrologic Engineering, v. 13, no. 7,13 p.

Moore, W.L., and Frankenfield, H.C., 1905, Daily river stages at river gage stations on the principal rivers of the United States: U.S. Department of Agriculture, U.S. Weather Bureau, Part 7, no. 339, 728 p.

Murphy, E.C., 1904, Destructive floods in the United States in 1903: U.S. Geological Survey Water-Supply Paper 96, 79 p.

National Agriculture Imagery Program, 2010, Aerial Photography Field Office - Imagery Programs, accessed May 10, 2012, at http://www.fsa.usda.gov/FSA/apfoapp?are $\mathrm{a}=$ home \&subject $=$ prog\&topic $=$ nai.

National Climatic Data Center, 2012a, National Oceanic and Atmospheric Administration, NEXRAD data inventory search, accessed May 10, 2012, at http://www.ncdc.noaa. gov.

National Climatic Data Center, 2012b, National Oceanic and Atmospheric Administration, Climate data online, accessed August 20, 2012, at http://www.ncdc.noaa.gov/cdo-web. 
National Weather Service, 2011, United States flood loss report - Water year 2011, accessed January 26, 2013, at http://www.nws.noaa.gov/hic/summaries/WY2011.pdf.

National Weather Service, 2012, Spring 2011 Middle \& Lower Mississippi River Valley floods: Service Assessment, $84 \mathrm{p}$.

Parrett, Charles, Melcher, N.B., and James, R.W., Jr., 1993, Flood discharges in the upper Mississippi River Basin, 1993: U.S. Geological Survey Circular 1120-A, 14 p.

Rantz, S.E., and others, 1982, Measurement and computation of streamflow: Volume 1, Measurement of stage and discharge: Volume 2, Computation of discharge: U.S. Geological Survey Water-Supply Paper 2175, 686 p.

Sullavan, N.J., 1974, Drainage areas of streams in ArkansasWhite River Basin: U.S. Geological Survey Open-File Report, 123 p.

U.S. Army Corps of Engineers, 2011, Little Rock District project, accessed September 13, 2011, at http://www.swl. usace.army.mil/.

U.S. Army Corps of Engineers, 2011b, Dam and lake information, accessed June 9, 2011, at http://www.swl. usace.army.mil/Missions/Recreation/Lakes/TableRockLake/ DamandLakeInformation.aspx.
U.S. Geological Survey, 1992, Guidelines for identifying and evaluating peak discharge errors: U.S. Geological Survey Office of Surface Water Technical Memorandum No.92.10.

U.S. Geological Survey, 2006, Flood hazards -A national threat: U.S. Geological Survey Fact Sheet 2006-3026, 2 p.

U.S. Geological Survey, 2009, Review and correction of the peak-flow file: Office of Surface Water Technical Memorandum SW09.01.

U.S Geological Survey, 2012, National Water Information System: Web Interface: U.S. Geological Survey, accessed June 2012, at http://waterdata.usgs.gov/nwis.

Watkins, K.B., Wailes, E.J., and Miller, Wayne, 2011, Arkansas economic losses due to flooding of crops: University of Arkansas Division of Agriculture, accessed July 1, 2012, at http://www.uaex.edu/depts/ag_economics/ publications/Ark_Economic_Losses_Flood_2011.pdf.

Wells, J.V.B., 1955, Floods of April 1952 in the Missouri River Basin: U.S. Geological Survey Water-Supply Paper 1260-B, 302 p.

Werner, M.G.F., 2001, Impact of grid size in GIS based flood extent mapping using a 1D flow model: Physical Chemistry Earth, v. 26, nos. 7-8, p. 517-522.

Zar, J.H., 1998, Biostatistical analysis (4th ed.): Englewood Cliffs, N.J., Prentice-Hall, Inc., 929 p. 

Appendix 1. High-water-mark identifiers, locations, elevations, and quality indicators for two stream reaches on the White River and two on the Black River; the vicinities of the communities of Holly Grove and Cotton Plant, Arkansas; a reach of the White River that includes the crossing of Interstate 40 north of De Valls Bluff, Ark.; and the Tailwaters of Beaver Dam near Eureka Springs, Ark., Table Rock Dam near Branson, Missouri, and Bull Shoals Dam near Flippin, Ark.

[ft, feet; Vertical coordinate data are referenced to the North American Vertical Datum of 1988 (NAVD 88); Horizontal coordinate data are referenced to the North American Datum of 1983; USACE, U.S. Army Corps of Engineers; USGS, U.S. Geological Survey; AHTD, Arkansas State and Highway Transportation Department; LR, Little Rock District; Mem, Memphis District; NA, not applicable; UNT, unnamed tributary; for bank of nearest watercourse, "right" and "left" refer to an observer looking in the downstream direction of the watercourse]

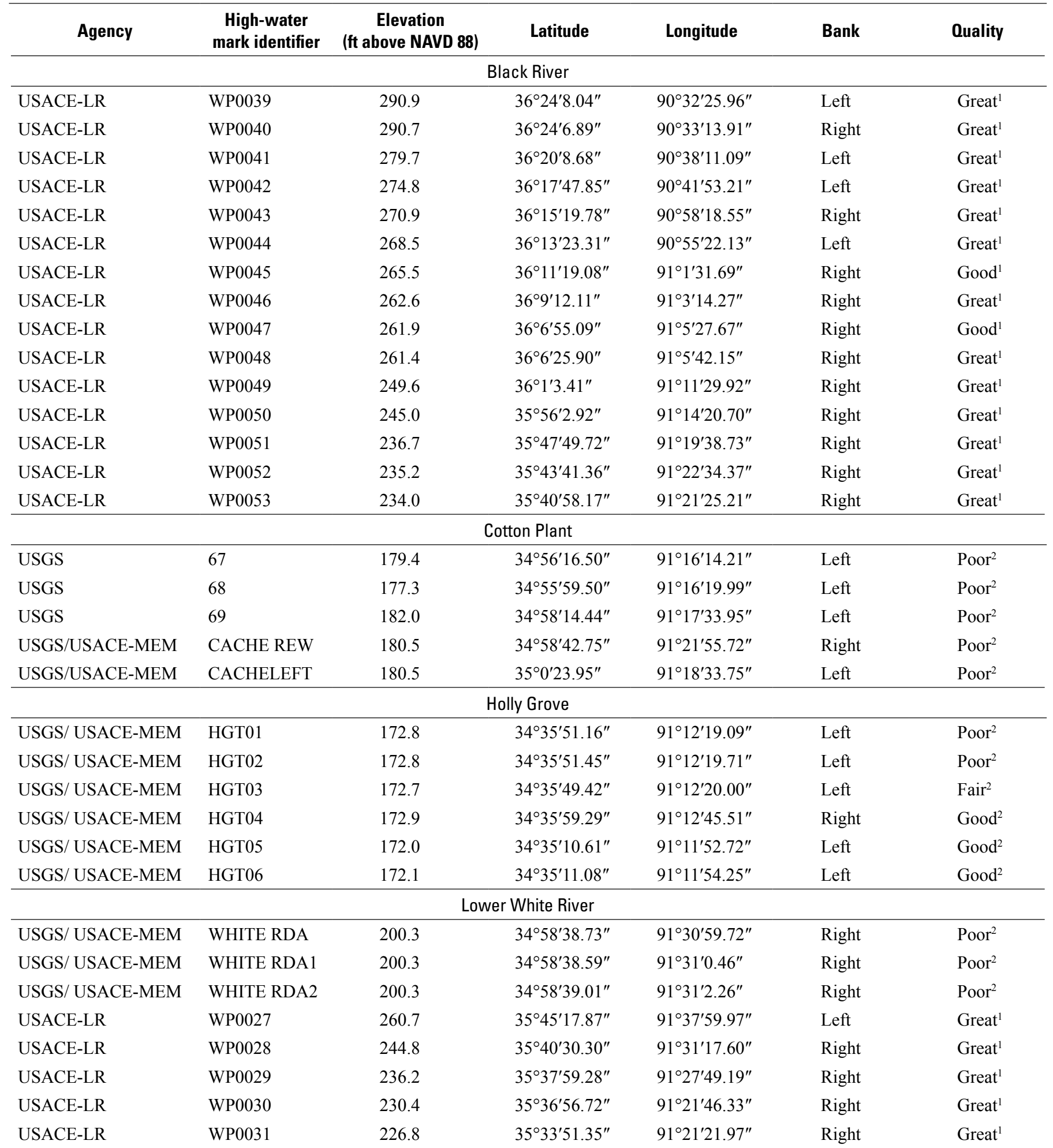


Appendix 1. High-water-mark identifiers, locations, elevations, and quality indicators for two stream reaches on the White River and two on the Black River; the vicinities of the communities of Holly Grove and Cotton Plant, Arkansas; a reach of the White River that includes the crossing of Interstate 40 north of De Valls Bluff, Ark.; and the Tailwaters of Beaver Dam near Eureka Springs, Ark., Table Rock Dam near Branson, Missouri, and Bull Shoals Dam near Flippin, Ark.-Continued

[ft, feet; Vertical coordinate data are referenced to the North American Vertical Datum of 1988 (NAVD 88); Horizontal coordinate data are referenced to the North American Datum of 1983; USACE, U.S. Army Corps of Engineers; USGS, U.S. Geological Survey; AHTD, Arkansas State and Highway Transportation Department; LR, Little Rock District; Mem, Memphis District; NA, not applicable; UNT, unnamed tributary; for bank of nearest watercourse, "right" and "left" refer to an observer looking in the downstream direction of the watercourse]

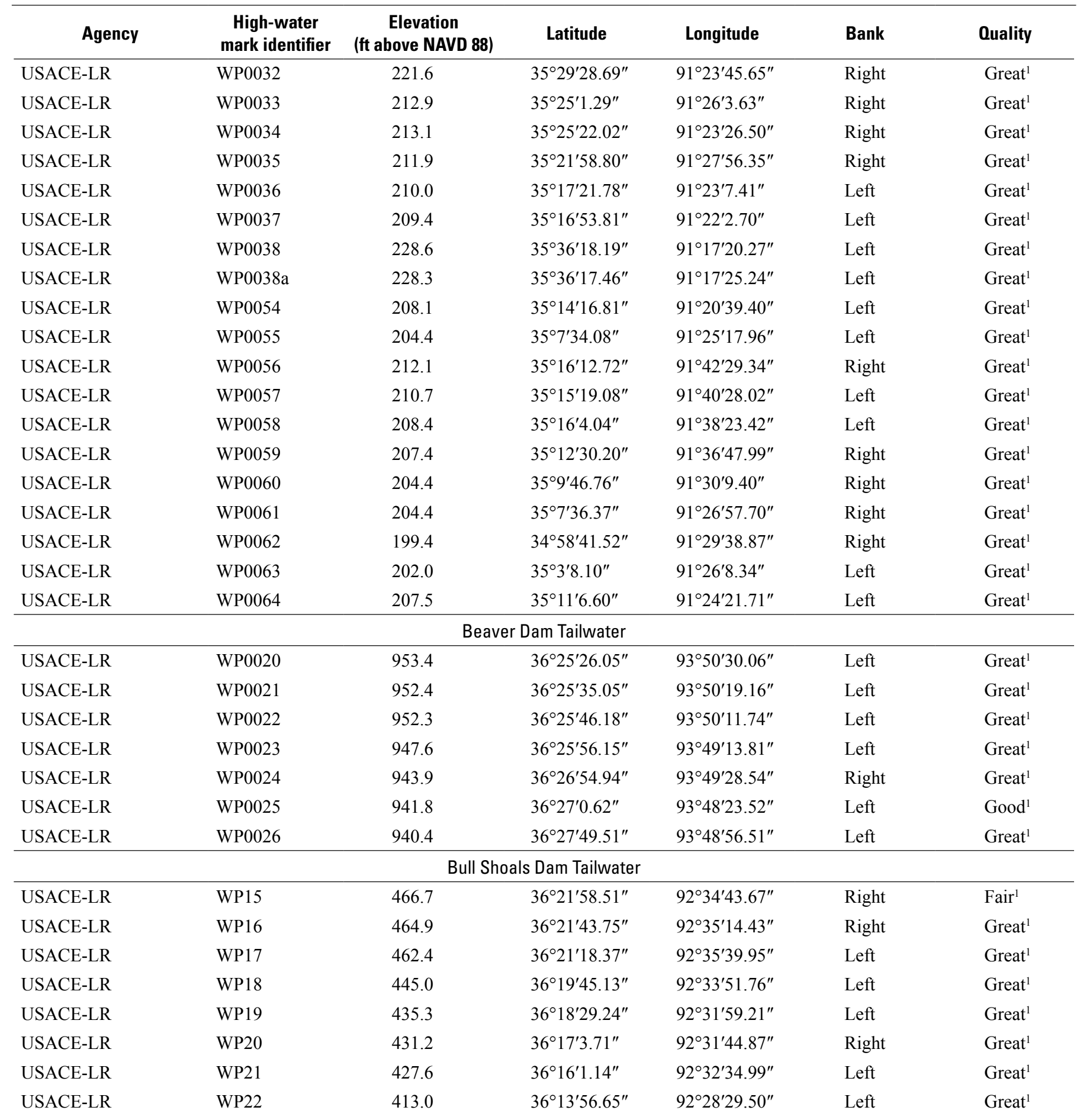


Appendix 1. High-water-mark identifiers, locations, elevations, and quality indicators for two stream reaches on the White River and two on the Black River; the vicinities of the communities of Holly Grove and Cotton Plant, Arkansas; a reach of the White River that includes the crossing of Interstate 40 north of De Valls Bluff, Ark.; and the Tailwaters of Beaver Dam near Eureka Springs, Ark., Table Rock Dam near Branson, Missouri, and Bull Shoals Dam near Flippin, Ark.-Continued

[ft, feet; Vertical coordinate data are referenced to the North American Vertical Datum of 1988 (NAVD 88); Horizontal coordinate data are referenced to the North American Datum of 1983; USACE, U.S. Army Corps of Engineers; USGS, U.S. Geological Survey; AHTD, Arkansas State and Highway Transportation Department; LR, Little Rock District; Mem, Memphis District; NA, not applicable; UNT, unnamed tributary; for bank of nearest watercourse, "right" and "left" refer to an observer looking in the downstream direction of the watercourse]

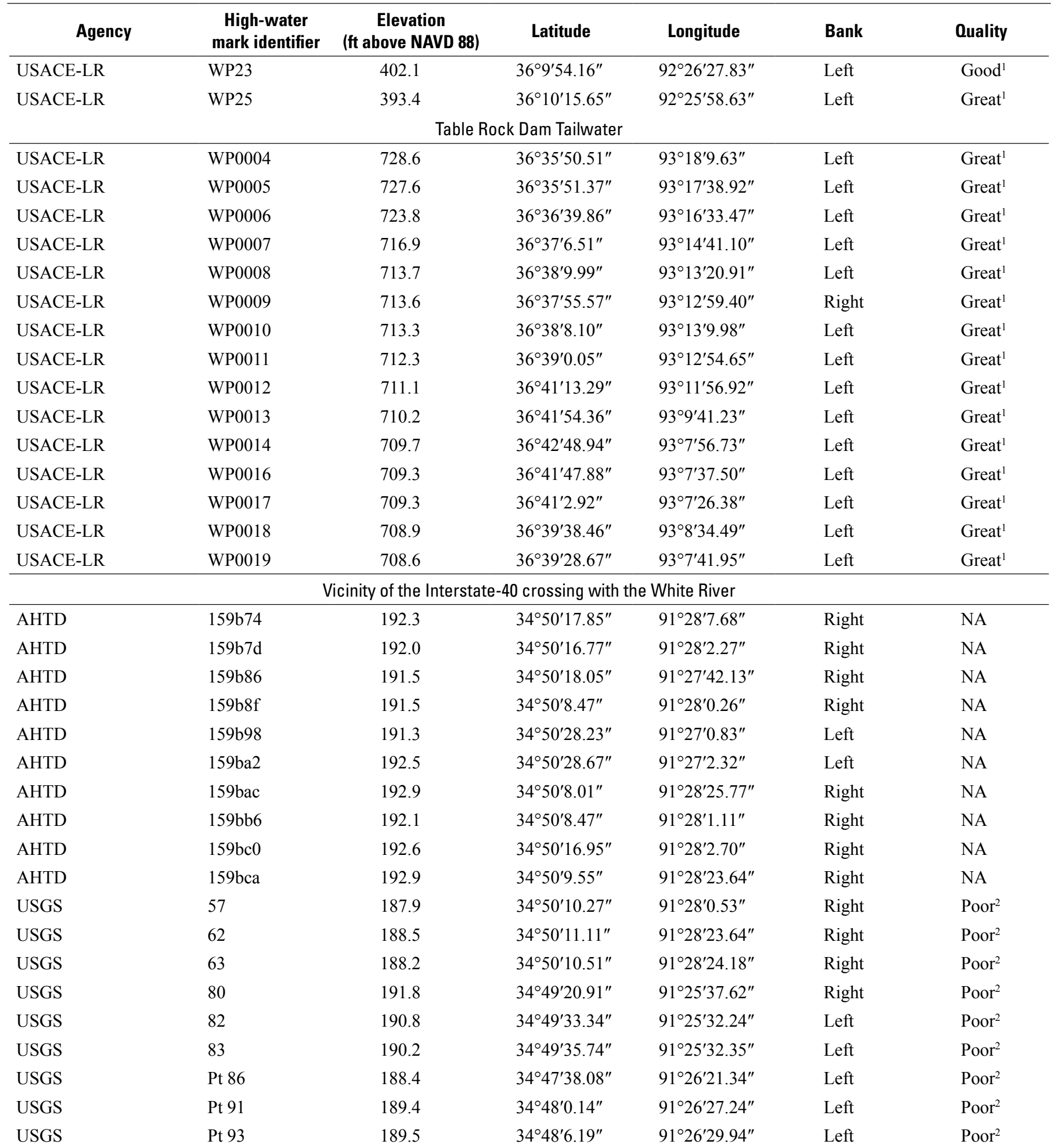




\section{Analysis and Inundation Mapping of the April-May 2011 Flood at Selected Locations}

Appendix 1. High-water-mark identifiers, locations, elevations, and quality indicators for two stream reaches on the White River and two on the Black River; the vicinities of the communities of Holly Grove and Cotton Plant, Arkansas; a reach of the White River that includes the crossing of Interstate 40 north of De Valls Bluff, Ark.; and the Tailwaters of Beaver Dam near Eureka Springs, Ark., Table Rock Dam near Branson, Missouri, and Bull Shoals Dam near Flippin, Ark.-Continued

[ft, feet; Vertical coordinate data are referenced to the North American Vertical Datum of 1988 (NAVD 88); Horizontal coordinate data are referenced to the North American Datum of 1983; USACE, U.S. Army Corps of Engineers; USGS, U.S. Geological Survey; AHTD, Arkansas State and Highway Transportation Department; LR, Little Rock District; Mem, Memphis District; NA, not applicable; UNT, unnamed tributary; for bank of nearest watercourse, "right" and "left" refer to an observer looking in the downstream direction of the watercourse]

\begin{tabular}{|c|c|c|c|c|c|c|}
\hline Agency & $\begin{array}{c}\text { High-water } \\
\text { mark identifier }\end{array}$ & $\begin{array}{c}\text { Elevation } \\
\text { (ft above NAVD 88) }\end{array}$ & Latitude & Longitude & Bank & Quality \\
\hline USGS & pt 99 & 189.2 & $34^{\circ} 47^{\prime} 57.77^{\prime \prime}$ & $91^{\circ} 26^{\prime} 36.92^{\prime \prime}$ & Left & Poor $^{2}$ \\
\hline USGS/USACE-MEM & I-40HWM01 & 187.6 & $34^{\circ} 50^{\prime} 16.99^{\prime \prime}$ & $91^{\circ} 28^{\prime} 1.64^{\prime \prime}$ & Right & Good $^{2}$ \\
\hline USGS/USACE-MEM & I-40HWM02 & 187.8 & $34^{\circ} 50^{\prime} 17.25^{\prime \prime}$ & $91^{\circ} 28^{\prime} 2.11^{\prime \prime}$ & Right & Good $^{2}$ \\
\hline USGS/USACE-MEM & I-40HWM03 & 187.7 & $34^{\circ} 50^{\prime} 15.78^{\prime \prime}$ & $91^{\circ} 28^{\prime} 1.13^{\prime \prime}$ & Right & Poor $^{2}$ \\
\hline USGS/USACE-MEM & I-40HWM06 & 187.8 & $34^{\circ} 50^{\prime} 10.27^{\prime \prime}$ & $91^{\circ} 28^{\prime} 0.53^{\prime \prime}$ & Right & Poor $^{2}$ \\
\hline USGS/USACE-MEM & I-40HWM07 & 187.6 & $34^{\circ} 50^{\prime} 8.46^{\prime \prime}$ & $91^{\circ} 28^{\prime} 0.90^{\prime \prime}$ & Right & Good $^{2}$ \\
\hline USGS/USACE-MEM & I-40HWMDN1 & 187.7 & $34^{\circ} 49^{\prime} 59.94^{\prime \prime}$ & $91^{\circ} 28^{\prime} 5.21^{\prime \prime}$ & Right & Poor $^{2}$ \\
\hline USGS/USACE-MEM & I-40HWMDN2 & 187.8 & $34^{\circ} 49^{\prime} 50.82^{\prime \prime}$ & $91^{\circ} 27^{\prime} 58.90^{\prime \prime}$ & Right & Fair $^{2}$ \\
\hline USGS/USACE-MEM & I-40LDN04 & 180.5 & $34^{\circ} 50^{\prime} 40.58^{\prime \prime}$ & $91^{\circ} 26^{\prime} 1.75^{\prime \prime}$ & Left & Poor $^{2}$ \\
\hline USGS/USACE-MEM & I-40LDN05 & 180.7 & $34^{\circ} 50^{\prime} 38.07^{\prime \prime}$ & $91^{\circ} 25^{\prime} 58.15^{\prime \prime}$ & Left & Good $^{2}$ \\
\hline USGS/USACE-MEM & I-40LDN06 & 180.7 & $34^{\circ} 50^{\prime} 30.14^{\prime \prime}$ & $91^{\circ} 25^{\prime} 52.93^{\prime \prime}$ & Left & Fair $^{2}$ \\
\hline USGS/USACE-MEM & I-40LUP01 & 192.6 & $34^{\circ} 50^{\prime} 53.76^{\prime \prime}$ & $91^{\circ} 26^{\prime} 6.50^{\prime \prime}$ & Left & Good $^{2}$ \\
\hline USGS/USACE-MEM & I-40LUP02 & 192.9 & $34^{\circ} 50^{\prime} 59.58^{\prime \prime}$ & $91^{\circ} 26^{\prime} 6.53^{\prime \prime}$ & Left & Good $^{2}$ \\
\hline
\end{tabular}

${ }^{1}$ The quality of high-water marks collected by USACE were subjectively rated in the field in order of mark confidence as "Great," "Good," "Fair," or "Poor" by USACE field personnel (Catherine Funkhouser, U.S. Army Corps of Engineers-Little Rock, written commun., 2012).

${ }^{2}$ The quality of high-water marks collected by USGS were rated in the field based on the perceived accuracy of the mark "Excellent," "Good," "Fair," or "Poor" (Lumia, 1986). 


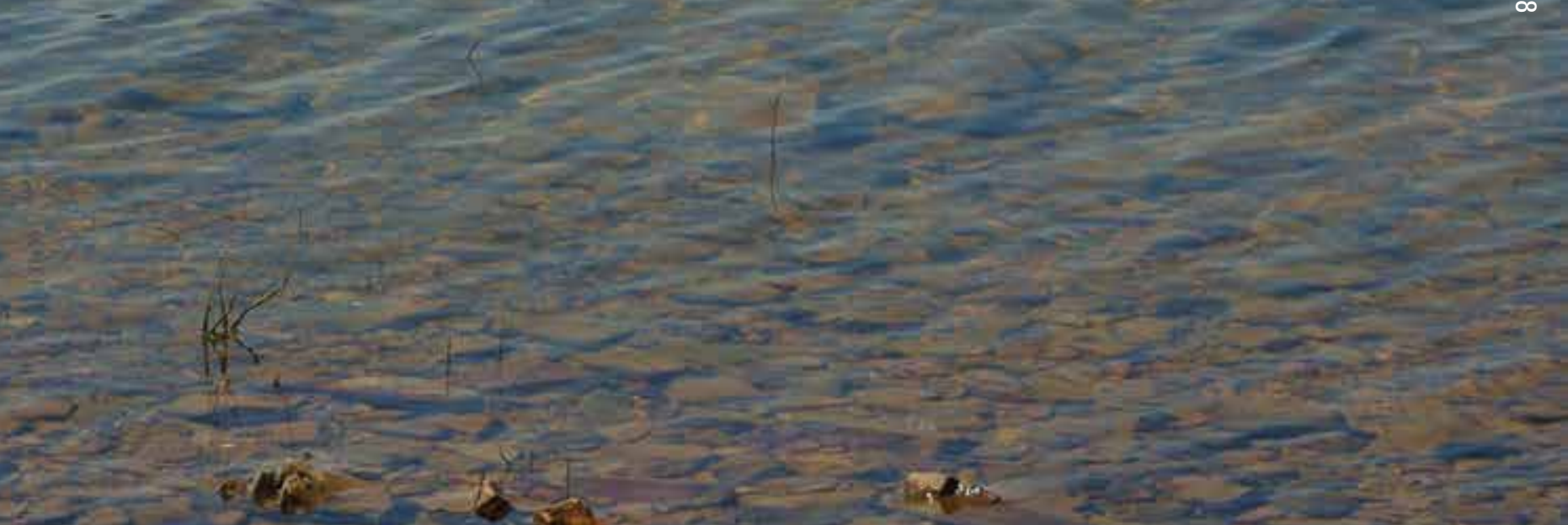

